\section{U.S. DEPARTMENT OF ENERGY}

\section{Office of}

ENERGY EFFICIENCY \& RENEWABLE ENERGY

\title{
Ventilation in Residential Care Environments
}

April 2021 


\section{Disclaimer}

This work was prepared as an account of work sponsored by an agency of the United States Government. Neither the United States Government nor any agency thereof, nor any of their employees, nor any of their contractors, subcontractors or their employees, makes any warranty, express or implied, or assumes any legal liability or responsibility for the accuracy, completeness, or any third party's use or the results of such use of any information, apparatus, product, or process disclosed, or represents that its use would not infringe privately owned rights. Reference herein to any specific commercial product, process, or service by trade name, trademark, manufacturer, or otherwise, does not necessarily constitute or imply its endorsement, recommendation, or favoring by the United States Government or any agency thereof or its contractors or subcontractors. The views and opinions of authors expressed herein do not necessarily state or reflect those of the United States Government or any agency thereof, its contractors or subcontractors.

Available electronically at Office of Scientific and Technical Information website (osti.gov) Available for a processing fee to U.S. Department of Energy and its contractors, in paper, from:

U.S. Department of Energy

Office of Scientific and Technical Information

P.O. Box 62

Oak Ridge, TN 37831-0062

OSTI osti.gov

Phone: 865.576 .8401

Fax: 865.576.5728

Email: reports@osti.gov

Available for sale to the public, in paper, from:

U.S. Department of Commerce

National Technical Information Service

5301 Shawnee Road

Alexandria, VA 22312

NTIS ntis.gov

Phone: 800.553 .6847 or 703.605 .6000

Fax: 703.605.6900

Email: orders@ntis.gov 


\title{
Ventilation in Residential Care Environments
}

\author{
Prepared by: \\ University of Nebraska-Lincoln \\ Prepared for: \\ Building Technologies Office \\ Office of Energy Efficiency and Renewable Energy \\ U.S. Department of Energy
}

April 2021

National Renewable Energy Laboratory Technical Monitor: Conor Dennehy 


\section{Acknowledgments}

This project was led by Dr. Kevin Grosskopf of the University of Nebraska-Lincoln under a subcontract (SUB-2020-10280) issued by the Alliance for Sustainable Energy, a management and operating contractor for the U.S. Department of Energy's National Renewable Energy Laboratory.

Acknowledged are the contributions of several other individuals and organizations including Roger Lautz, P.E. of Affiliated Engineers Incorporated, Phil Arnold of SafeTraces, Dr. Ehsan Mousavi-Rizi of Clemson University, and Dr. Josephine Lau of the University of Nebraska-Lincoln.

\section{Table of Contents}

Executive Summary ………………………………………………………………………... 1

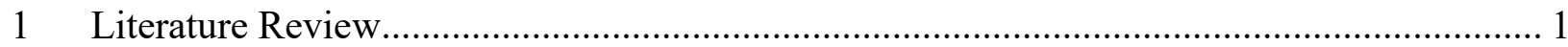

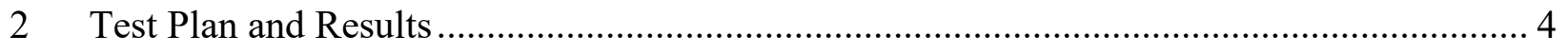

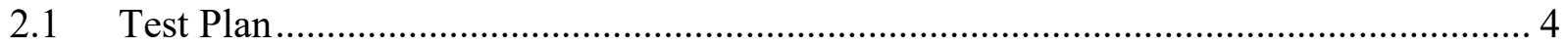

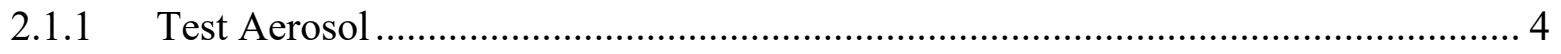

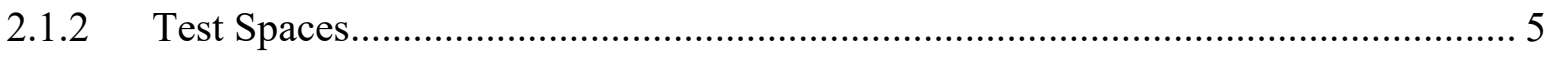

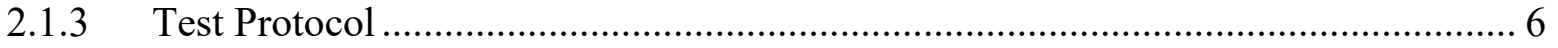

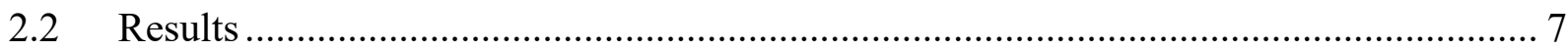

2.2.1 Resident Room Contaminant Load .............................................................. 8

2.2.2 Resident Room Transmission to Corridor ...................................................... 10

2.2.3 Corridor Transmission to Resident Rooms.......................................................... 13

2.2.4 Resident Room Transmission to Staff Room................................................ 14

2.2.5 Isolation Zone Transmission to Common Areas .............................................. 16

2.2.6 Isolation Zone Transmission to HVAC Systems ............................................. 18

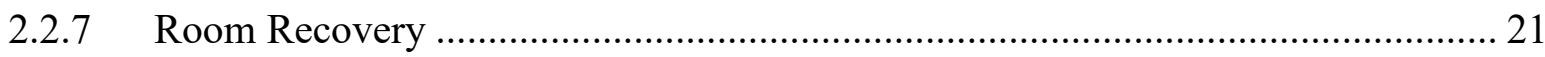

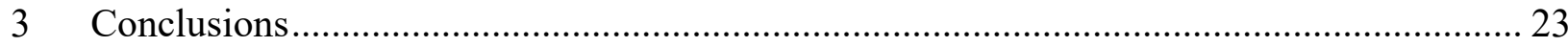

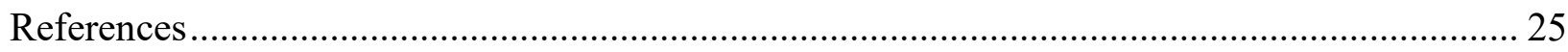

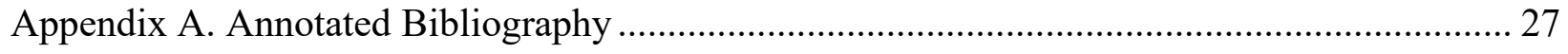

Appendix B. Test Results (Heat Maps) ….................................................................. 58

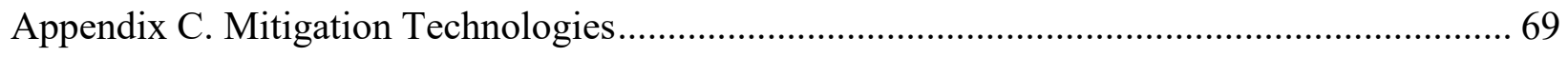




\section{Executive Summary}

The purpose of this study is to evaluate the effect of ventilation rate, directional airflow (e.g., pressure relationships), and airflow barriers on bioaerosol concentration and movement within assisted-living and residential care environments. Included within this report is a comprehensive literature review, field data collection test plan, and an evaluation of commercially available mitigation technologies related to the transmission of SARS-CoV-2 ("COVID-19") in long-term care (LTC) environments. Additionally, this report discusses aerosol testing in an actual LTC facility using the test plan developed herein.

Nearly 1.5 million people live in 16,000 nursing homes in the United States. As of Dec. 20, 2020, the Centers for Medicare \& Medicaid Services identified a total of 662,549 confirmed and suspected COVID-19 cases in these and other LTC facilities, resulting in 92,373 deaths. At this time, COVID-19 cases in LTC facilities accounted for only 3\% of the U.S. total of 21 million confirmed cases, yet nearly a third of the 350,000 total U.S. deaths.

Preliminary studies have found little correlation between the quality of care and transmission of COVID-19 in these facilities, suggesting that even the best infection control practices may not be effective in containing the spread of this likely airborne disease. As a result, many LTC facilities have implemented quarantine procedures and other measures to isolate infectious residents from the general population. Unfortunately, most LTC facilities were not designed for airborne infection control, and guidance for retrofitting existing LTC spaces for isolation is limited.

\section{Literature Review}

Of the 1.5 million people living in 16,000 U.S. nursing homes, $90 \%$ are over 65 years of age and half are 85 years of age or older (Centers for Disease Control [CDC] 2016). For decades, this vulnerable population has shared air, food, and healthcare in overcrowded settings ideal for the spread of infection. Each year, 2-3 million nursing home infections occur in the United States, resulting in 150,000 hospitalizations, 388,000 deaths, and up to $\$ 2$ billion in additional healthcare costs (Diaz-Decaro et al. 2018). In 2020, nursing home residents accounted for less than $0.5 \%$ of the U.S. population but almost $30 \%$ of its COVID-19 deaths. Prior to COVID-19, comparable numbers of nursing home residents died each year from seasonal influenza, respiratory syncytial virus, and pneumonia — despite vaccination rates exceeding $80 \%$. Only since COVID-19 have the inadequacies of infection control in nursing homes and other skilled nursing, assisted living, and LTC facilities been brought to the forefront of the public conscious.

New infection control strategies must be considered to contain infectious respiratory outbreaks in U.S. nursing homes, including measures to provide temporary airborne isolation capacity in existing facilities. This position is highlighted by the increasing prevalence of respiratory disease in nursing homes, the limited efficacy of vaccines and current infection control practices, and the estimated 5.3 million people who will require nursing home care in the United States by 2030 (Montoya et al. 2011). 
Transmission of COVID-19 can occur through direct or indirect contact with infected people or contaminated surfaces (i.e., "fomites") through saliva and respiratory secretions (World Health Organization 2020). Growing evidence suggests COVID-19 may also be transmitted through the air in poorly ventilated spaces by aerosolized or desiccated droplets (i.e., "droplet nuclei”) less than $5 \mu \mathrm{m}$ in diameter. Normal breathing and talking have been shown to produce droplets conducive to aerosol transport (Anderson et al. 2020), with the peak concentrations of SARSCoV-2 appearing in two distinct size ranges: $<1.0 \mu \mathrm{m}$ and $>2.5 \mu \mathrm{m}$ (Zhao et al. 2020). For moderately symptomatic individuals, viral shedding may range from $1.3 \times 10^{3}$ copies $/ \mathrm{m}^{3}$ of room air for normal breathing to $7.5 \times 10^{6}$ viral copies for frequent coughing. Consistent with these findings, airborne transmission of COVID-19 has been implicated in several super-spreading events where social distancing, masking, surface disinfection, and other infectious control procedures were observed, further indicating the virus may remain airborne and viable (e.g., infectious) for several hours and over distances greater than $2 \mathrm{~m}(6 \mathrm{ft})$. In fact, spatial infection patterns for similar coronavirus outbreaks such as SARS-CoV-1 and Middle East Respiratory Syndrome coronavirus (MERS-CoV) suggest SARS-CoV-2 may be capable of traveling more than $30 \mathrm{~m}$ and may remain viable much longer once it settles on surfaces or objects.

A review of 9,395 nursing homes in 30 states found nearly one-third (31.4\%) had experienced a COVID-19 outbreak, with an average of 19.8 cases. Larger facilities in urban settings were significantly more likely to have a COVID-19 outbreak $(\mathrm{p}<0.05)$. COVID-19 outbreaks, however, were not correlated to nursing home quality of care as determined by the Centers for Medicare \& Medicaid Services five-star quality rating system (Abrams et al. 2020). In fact, several peer-reviewed case studies by the American Geriatrics Society document very rapid and widely disseminated outbreaks despite visitor exclusion, cessation of communal dining and group activities, regular resident and staff screenings, universal masking, and aggressive social distancing policies (Blackman et al. 2020). In nearly every case, more than $30 \%$ of residents tested positive for COVID-19 within two to three weeks of the first positive test result (Arons et al. 2020; Kimball et al. 2020) despite early adoption of infection prevention and control measures. Of those, nearly one-third ultimately died.

As hospitals reach acute care capacity, nursing homes are retaining greater numbers of COVID19-infected residents longer (Lynch et al. 2020). Given that transmission of SARS-CoV-2 through the air is sufficiently likely, airborne exposure to the virus should be controlled (ASHRAE 2020). Nursing homes, however, are not designed for airborne infection control, and isolation is difficult to achieve (Miller et al. 2020). Common limitations in existing facilities are the inability to maintain thermal comfort while providing added ventilation air, directional airflow, increased air filtration, and sufficient isolation space to physically separate infectious residents and attending staff from the general population. 
Table 1. American National Standards Institute (ANSI)/ASHRAE/American Society for Healthcare Engineering (ASHE) Standard 170 Design Parameters for Nursing Facility Resident Room and In-Patient Airborne Infectious Isolation Room (AIIR)

\begin{tabular}{|l|c|c|c|c|c|}
\hline & $\begin{array}{c}\text { Air } \\
\text { Pressure }\end{array}$ & $\begin{array}{c}\text { Outdoor } \\
\text { ACH }\end{array}$ & $\begin{array}{c}\text { Total } \\
\text { ACH }\end{array}$ & $\begin{array}{c}\text { Recirculated } \\
\text { Air }\end{array}$ & $\begin{array}{c}\text { Air } \\
\text { Filtration }\end{array}$ \\
\hline Resident Room & NR $^{1}$ & 2 & 2 & NR $^{1}$ & MERV $^{2} 7$ \\
\hline Isolation Room (AllR) & Negative & 2 & 12 & No & MERV 13 \\
\hline
\end{tabular}

${ }^{1}$ No requirement. Neutral air pressure relationship to adjacent areas.

${ }^{2}$ Minimum efficiency reporting value.

${ }^{3}$ General in-patient requirement. No recirculation. All room air exhausted directly to outdoors.

As defined by ASHRAE Standard 170 (Table 1), airborne infectious isolation requires dedicated heating, ventilating, and air-conditioning (HVAC) systems that provide several room air changes per hour $(\mathrm{ACH})$ to dilute and remove airborne contaminants. Airborne isolation also requires airflow from spaces outside of the isolation zone inward toward spaces within the isolation zone to contain airborne contaminants. By comparison, HVAC systems in most nursing homes do not maintain directional airflow, have significantly fewer room air changes and minimal air filtration, and recirculate air between resident rooms and communal areas.

Nursing homes and other LTC facilities may, however, have reserve HVAC capacity to increase air filtration and outdoor air ventilation, especially during milder weather. Nursing homes may further consider the use of room air cleaners with upper-room ultraviolet (UV) disinfection or high-efficiency particulate air (HEPA) filters (Schoen 2020). HEPA filters may also be used to clean recirculated air or air that cannot be exhausted directly to the outdoors, although the use of high-efficiency filters can diminish the amount of air supplied to the room and cause more air to bypass the filter (National Air Filtration Association 2020). HVAC systems may also be operated longer than would otherwise be required for climate control to enhance the effects of both added ventilation and filtration.

In addition to engineering controls targeting airborne transmission, nursing homes should consider procedural measures as part of infectious isolation or quarantine planning. Such measures may include limits to avoid overcrowding, dedicated isolation staff, restricted access, and limits on resident transport and movement. Additional measures may include dedicated resident bathrooms and confining aerosol generating procedures to resident rooms, preferably negative pressure rooms if possible (ASHE 2020).

Included in this report is an annotated bibliography of more than 90 publications related to COVID-19 and other respiratory diseases in skilled nursing facilities and similar residential care environments (see Appendix A). 


\section{Test Plan and Results}

\subsection{Test Plan}

To evaluate the effectiveness of methods to create temporary airborne isolation spaces in existing LTC facilities, staff from Affiliated Engineers, Inc. converted a residential wing of an actual LTC facility into an experimental isolation test space. The experimental test space was retrofitted to provide ASHRAE Standard 170 ventilation rates for airborne isolation as well as directional airflow, air filtration, and physical separation (e.g., anterooms). A DNA tracer aerosol was used to simulate the contaminant load from infectious residents and staff. Contaminant concentrations and movement within the experimental test space and to adjacent spaces were then compared to an identical control test space (at the same facility) without airborne isolation modifications.

\subsubsection{Test Aerosol}

The aerosol used to simulate airborne respiratory droplets was a proprietary solution provided by SafeTraces, an environmental health and safety organization specializing in rapid testing solutions for contaminant tracing and sanitation in food, pharma, healthcare, and related industries. The aerosol consisted of a water-soluble blend of DNA-coded particles sized and formulated to simulate desiccated respiratory droplets (known as droplet nuclei). Such droplets have a mean aerodynamic diameter of $<5 \mu \mathrm{m}$ and have been implicated in the airborne transmission of diseases similar to COVID-19 such as SARS-CoV-1 and MERS-CoV.

DNA-coded particles released into the LTC environment were then collected by air and surface sampling equipment and analyzed by polymerase chain reaction (PCR) detection technology. PCR technology can determine the relative concentration of DNA-coded particles within a space and enable test particles to be differentiated from background or ambient particles. Because each aerosol solution was formulated with a unique DNA code, particles could be further traced to their source. As a result, DNA-coded particles were simultaneously released and traced from multiple locations within the LTC facility, reducing testing time and disruption to residents and staff.

Table 2. Particle Size Distribution of Tracer Aerosol by Particle Count

\begin{tabular}{|c|c|c|c|c|c|c|}
\hline & $\mathbf{0 . 3} \boldsymbol{\mu m}$ & $\mathbf{0 . 5} \boldsymbol{\mu m}$ & $\mathbf{1 . 0} \boldsymbol{\mu m}$ & $\mathbf{2 . 5} \boldsymbol{\mu m}$ & $\mathbf{5} \boldsymbol{\mu m}$ & $\mathbf{1 0} \boldsymbol{\mu m}$ \\
\hline Minimum & $40.3 \%$ & $21.9 \%$ & $4.0 \%$ & $0.7 \%$ & $0.2 \%$ & $0.1 \%$ \\
\hline Maximum & $73.1 \%$ & $22.8 \%$ & $17.2 \%$ & $16.2 \%$ & $3.1 \%$ & $0.4 \%$ \\
\hline Average & $56.7 \%$ & $22.4 \%$ & $10.6 \%$ & $8.4 \%$ & $1.7 \%$ & $0.2 \%$ \\
\hline
\end{tabular}

The particle size distribution of the tracer aerosol was analyzed independently at the University of Nebraska-Lincoln and Clemson University prior to testing. Each release generated approximately $1.5 \times 10^{3}$ particles/L of air, or an average of $2.7 \times 10^{5}$ particles total. Tests confirmed that more than $98 \%$ of the aerosol by particle count was in the airborne size range of $<5 \mu \mathrm{m}$. 


\subsubsection{Test Spaces}

Test spaces included one residential wing designated as the control test space and another identical wing designated as the experimental test space. Test spaces consisted of an entry foyer, corridor, and six resident rooms, one of which was used as a staff room. Each resident room was approximately $175 \mathrm{ft}^{2}$, and the test spaces including resident rooms, corridor, and foyer were approximately $1,500 \mathrm{ft}^{2}$. Testing in the control space was performed under normal operating conditions according to ANSI/ASHRAE/ASHE Standard-170 guidelines. Testing in the experimental space was performed under modified temporary isolation conditions to include physical separation of the resident wing from the facility, anterooms at the entrance to each resident space (Figure 1), higher ventilation rates, negative (inward) airflow, and HEPA return air filtration.

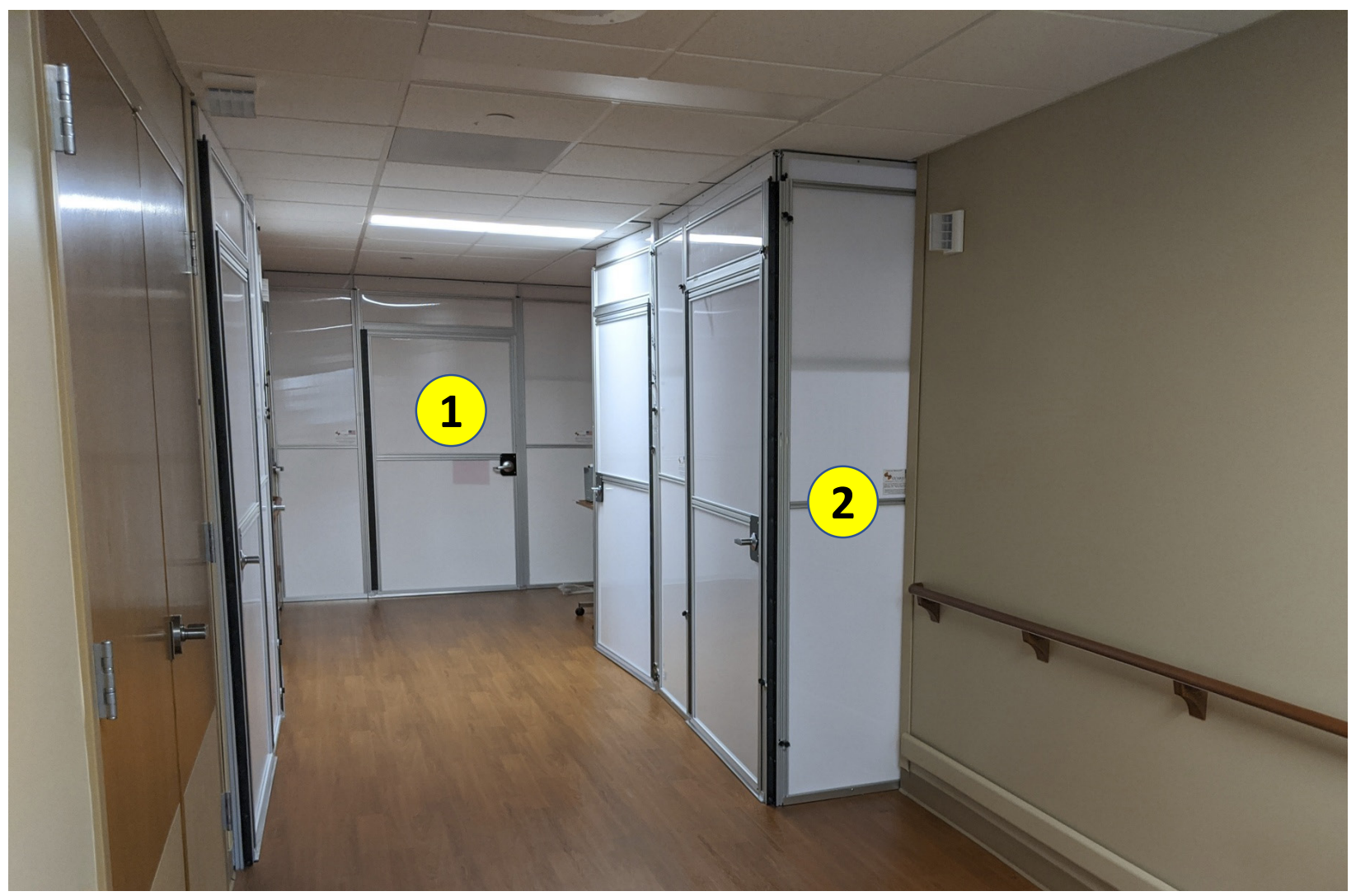

Figure 1. Experimental isolation test space $(1=$ controlled entrance, $2=$ temporary anterooms $)$

Photo by Phil Arnold, SafeTraces

Resident rooms in the control test space were conditioned with +75 cubic feet per minute (cfm) of supply air, $-10 \mathrm{cfm}$ of return air, and $-65 \mathrm{cfm}$ of bathroom exhaust, producing three total air changes per hour (TACH) and a neutral air pressure relationship with the corridor (Figure 2). Modified resident rooms in the experimental test space were conditioned with $+220 \mathrm{cfm}$ of supply air, $-240 \mathrm{cfm}$ of return air, and $-80 \mathrm{cfm}$ of bathroom exhaust, producing $12 \mathrm{TACH}$ and a negative air pressure relationship with the corridor (Figure 3). 


\subsubsection{Test Protocol}

A total of four tests were conducted - two in the control test space and two in the experimental test space. For each space, one test was conducted at 30\% outside air and another at $100 \%$ outside air. For each test, approximately $10-12 \mathrm{~mL}$ of DNA-coded tracer aerosol was released from four locations: two resident rooms, a staff room, and the central corridor. For each test, air filter samples $(9 \mathrm{~L} / \mathrm{min})$ were collected at a total of 12 locations: seven locations within the isolation test space, three in adjacent spaces outside of the test space, and one each in the supply and return air duct. The duration of each test from aerosol release to cessation of sampling was approximately 40 minutes. For all tests, doors remained closed for the duration of testing.

Table 3. Control and Experimental Test Space ACH at 30\% and 100\% Outside Air (OA)

\begin{tabular}{|c|c|c|c|c|}
\hline \multirow{2}{*}{} & \multicolumn{2}{|c|}{$\mathbf{3 0} \%$ OA Test } & \multicolumn{2}{c|}{$\mathbf{1 0 0 \%}$ OA Test } \\
\cline { 2 - 5 } & Outdoor ACH & Total ACH & Outdoor ACH & Total ACH \\
\hline Control Test Space & 1 & 3 & 3 & 3 \\
\hline Experimental Test Space & 3 & 12 & 8 & 12 \\
\hline
\end{tabular}

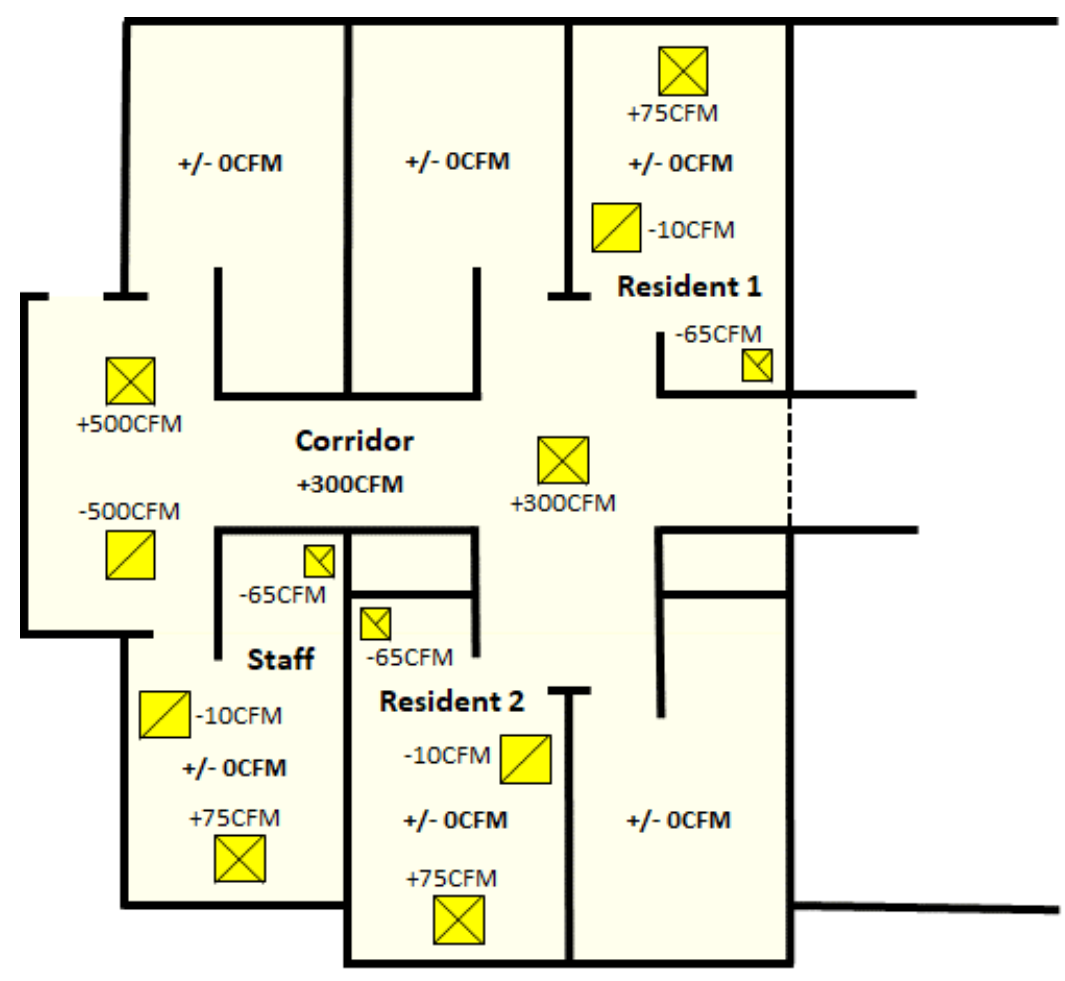

Figure 2. Control test space airflow configuration 


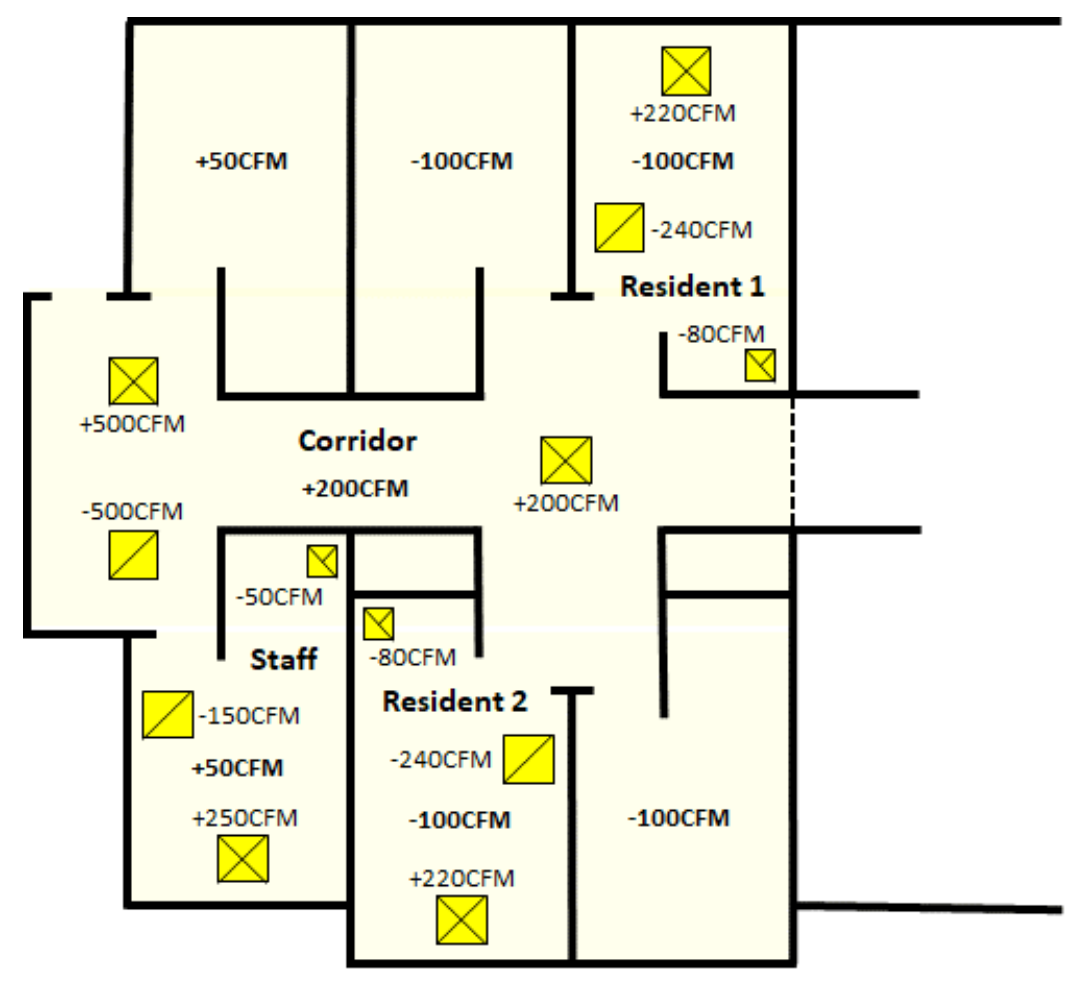

Figure 3. Experimental test space airflow configuration

\subsection{Results}

To evaluate the effectiveness of temporary isolation in LTC facilities, we analyzed the effects of ventilation, directional airflow, and physical airflow barriers on the concentration and containment of the tracer aerosol with respect to resident rooms and adjacent spaces. For each test, PCR analysis was used to produce a DNA tracer reduction $\log _{10}$ value for each of the 12 sample locations in each test space. Based on these values, the relative concentration of DNA tracer aerosol was determined for each sample location. "Heat maps" were then created to observe the effects of ventilation, directional airflow, and physical airflow barriers on the spatial distribution of the tracer aerosol from each of the four aerosol release points in each test space. Heat maps for all tests, including a total of 16 aerosol release points and 48 sample locations, are provided in Appendix B. 


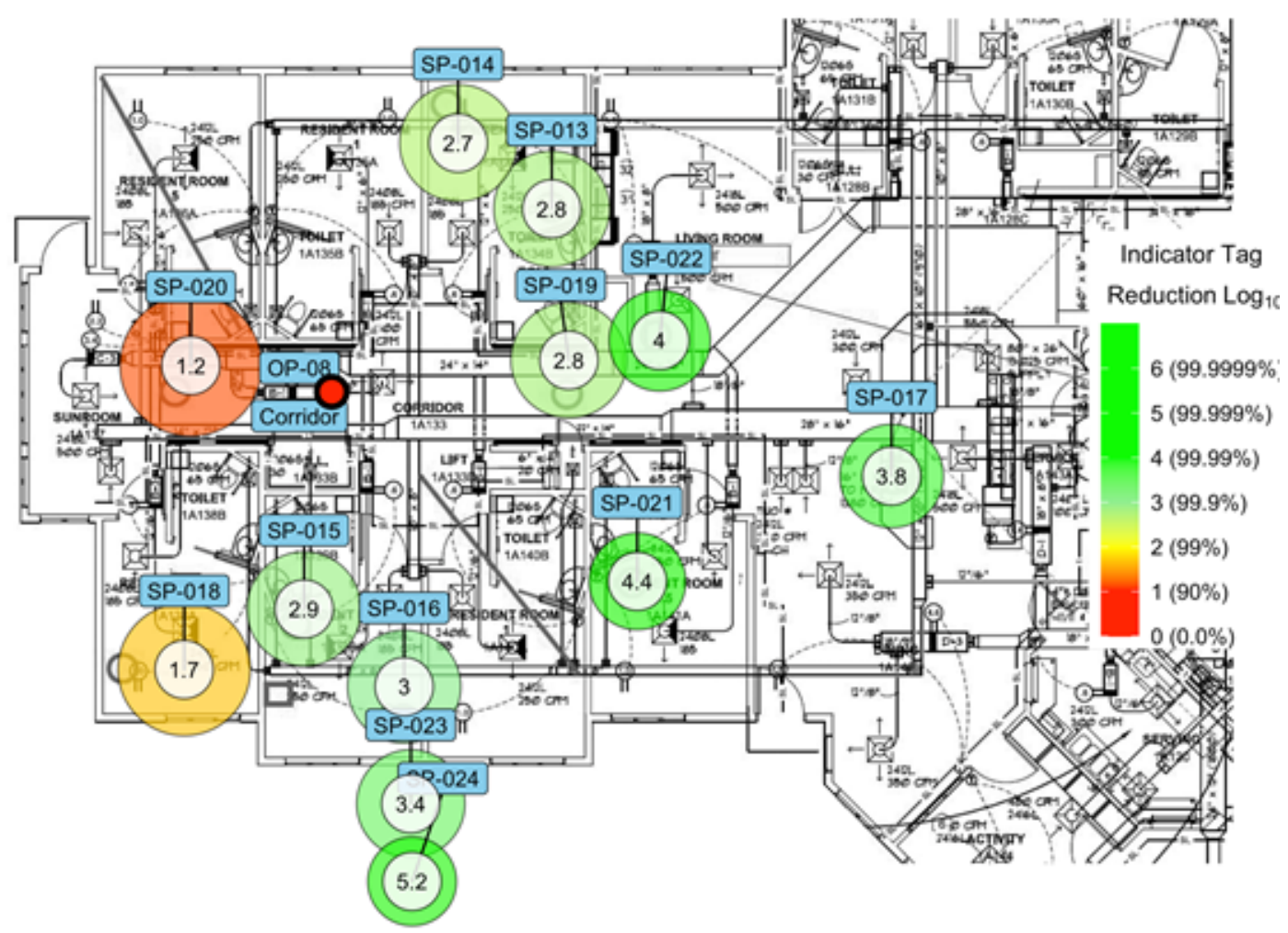

Figure 4. Example heat map showing corridor aerosol release (control test space at 1 outdoor air change per hour $[\mathrm{OACH}]$ and $3 \mathrm{TACH}) . \mathrm{SP}=$ sample locations, $\mathrm{OP}=$ aerosol release point.

From this data, we evaluated seven environmental transmission scenarios in greater detail:

- Resident room contaminant load

- Resident room transmission to corridor

- Corridor transmission to resident rooms

- Resident room transmission to staff room

- Isolation zone transmission to common areas*

- Isolation zone transmission to HVAC systems*

- Room recovery.*

* sample locations outside of test space

\subsubsection{Resident Room Contaminant Load}

To evaluate the effect of ventilation on contaminant load within resident rooms and to assess exposure risks to attending healthcare workers, DNA tracer aerosol was released inside resident rooms 1 and 2 and sampled under four different air change rates. For each test, tracer aerosol was released at the head of the resident room bed toward the opposite corner of the room at a height 
of $0.8 \mathrm{~m}$ (30 in.) above the floor. DNA tracer samples were then collected for 40 minutes at two locations in each resident room, one each at the foot of the bed and between the bed and bathroom at a height of $0.8 \mathrm{~m}$ (30 in.) above the floor (Figure 5). During tests, doors between resident rooms and corridors remained closed while bathroom doors inside resident rooms remained open.

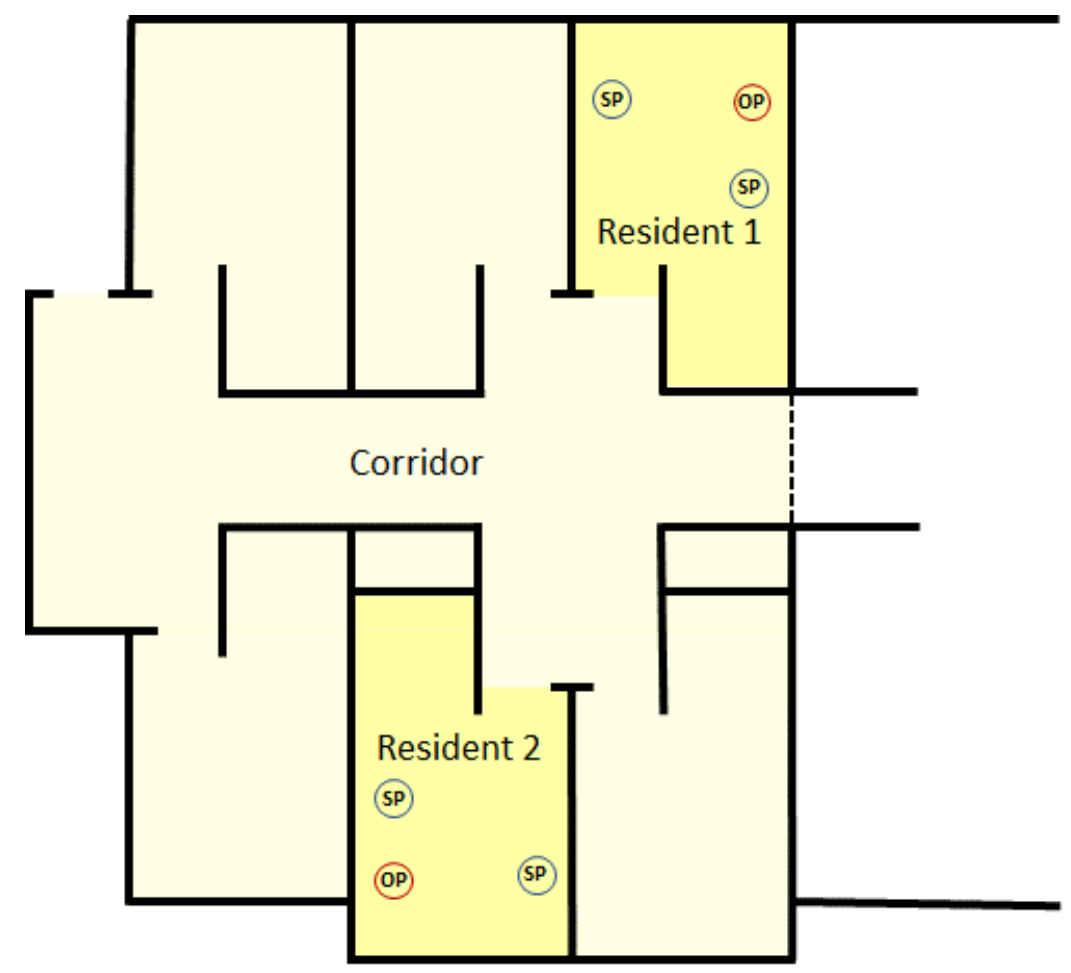

Figure 5. Resident room DNA tracer aerosol release and sampling locations (SP = sample locations, OP = aerosol release point)

Following PCR analyses of resident room samples, moderate contaminant load reductions were associated with increasing ventilation rates. Specifically, increasing ventilation rates from 1 to 3 $\mathrm{OACH}$ increased the average DNA tracer reduction $\log _{10}$ value from 1.15 to 1.23 , corresponding to a contaminant load reduction of approximately $17 \%$ from 70,795 particles per liter $(\mathrm{p} / \mathrm{L})$ of indoor air to $58,884 \mathrm{p} / \mathrm{L}$ (Figure 6). Increasing ventilation rates from 3 to $8 \mathrm{OACH}$ further increased the average DNA tracer reduction $\log _{10}$ value from 1.23 to 1.40 , corresponding to an additional contaminant load reduction of approximately $33 \%$ from $58,884 \mathrm{p} / \mathrm{L}$ to $39,811 \mathrm{p} / \mathrm{L}$. On average, each outdoor air change was associated with a 7\% contaminant load reduction. Overall, contaminant load reductions within resident rooms were strongly correlated to outdoor air change rates $\left(r^{2}>0.98\right)$. In contrast, contaminant load reductions were weakly correlated to total air change rates $\left(r^{2}<0.49\right)$. Increasing TACH from 3 to 12 while holding outdoor air change rate constant did not result in a significant reduction in contaminant load. Similarly, there was weakly observed correlation between air pressure relationships and changes in contaminant load in either resident room. 


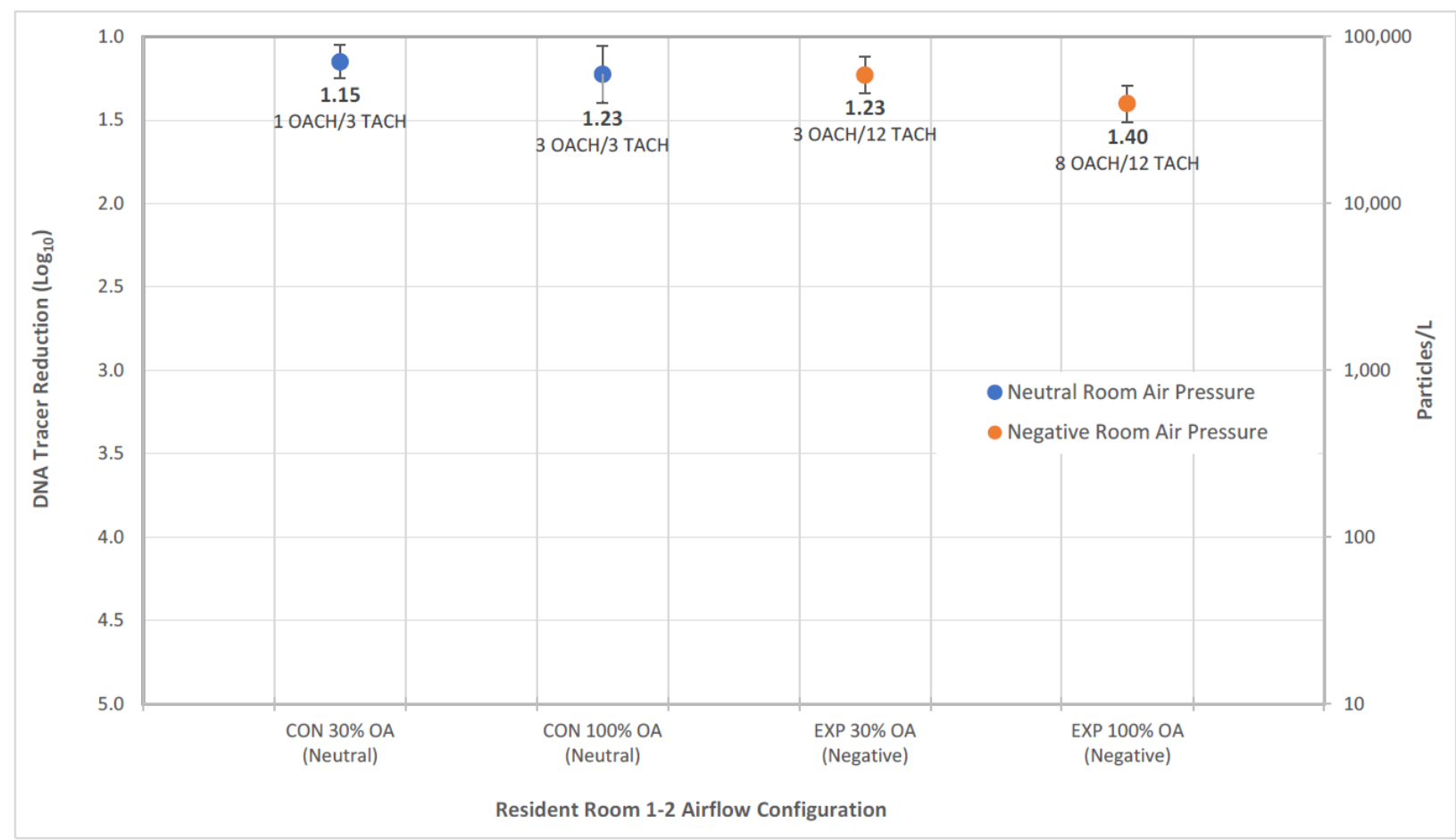

Figure 6. Resident room DNA tracer reduction $\log _{10}$ value and corresponding particle concentration (p/L) compared to resident room air change rate and directional airflow, using standard deviation/SQRt of the sample size

\subsubsection{Resident Room Transmission to Corridor}

DNA tracer samples were also collected at two locations in the corridor adjacent to resident rooms to evaluate the effect of directional airflow on the containment of contaminants to resident rooms 1 and 2. Tracer samples were collected for 40 minutes at either end of the corridor at a height of approximately $0.8 \mathrm{~m}$ (30 in.) above the floor (Figure 7). Of note, resident rooms in the experimental test space under negative room air pressure were equipped with anterooms. Resident rooms in the control test space under neutral room air pressure were not equipped with anterooms. Doors between resident rooms, anterooms, and the corridor remained closed during tests.

Following PCR analyses of corridor samples, reductions in tracer aerosol movement from resident rooms to the corridor were associated with directional airflow. With positive air pressure in the corridor and neutral air pressure in the resident rooms (moderate inward airflow), the average DNA tracer reduction $\log _{10}$ value in the corridor ranged between 3.83 to 3.98 , corresponding to a contaminant load of approximately 105 to $148 \mathrm{p} / \mathrm{L}$ (Figure 8). With positive air pressure in the corridor and negative air pressure in the resident rooms (strong inward airflow), the average DNA tracer reduction $\log _{10}$ value in the corridor ranged between 4.45 and 5.10 , corresponding to a contaminant load of approximately 10 to $35 \mathrm{p} / \mathrm{L}$. Overall, tracer aerosol movement from the resident rooms to the corridor was correlated to directional airflow $\left(r^{2}>0.90\right)$. In contrast, air change rates and subsequent contaminant loads in resident rooms were weakly correlated to contaminant loads in the corridor $\left(r^{2}<0.46\right)$. Working with directional 
airflow, room doors likely contributed to the containment of airborne contaminants to resident rooms. With resident room doors closed, tracer aerosol movement from rooms to the corridor was greatly reduced regardless of neutral or negative airflow mode or the use of anterooms.

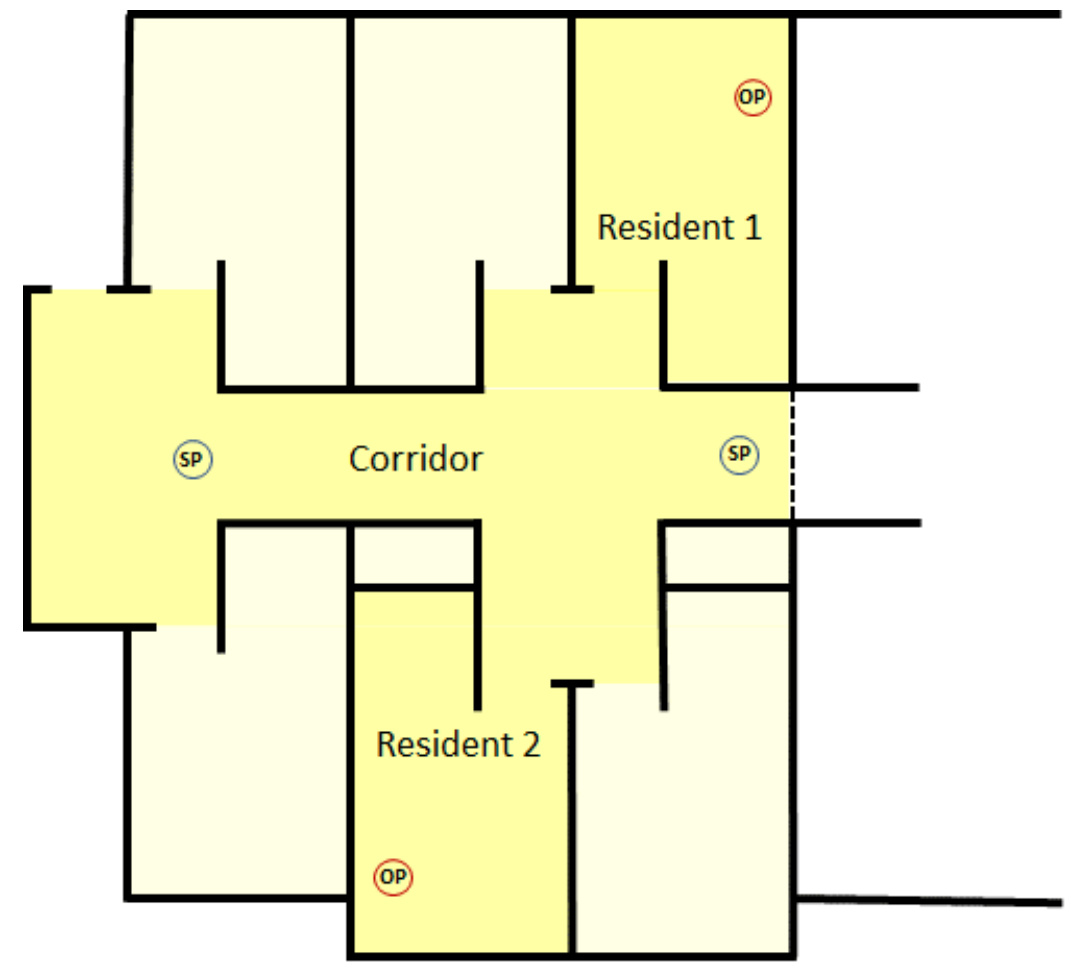

Figure 7. Resident room DNA tracer aerosol release and corridor sampling locations 
Ventilation in Residential Care Environments

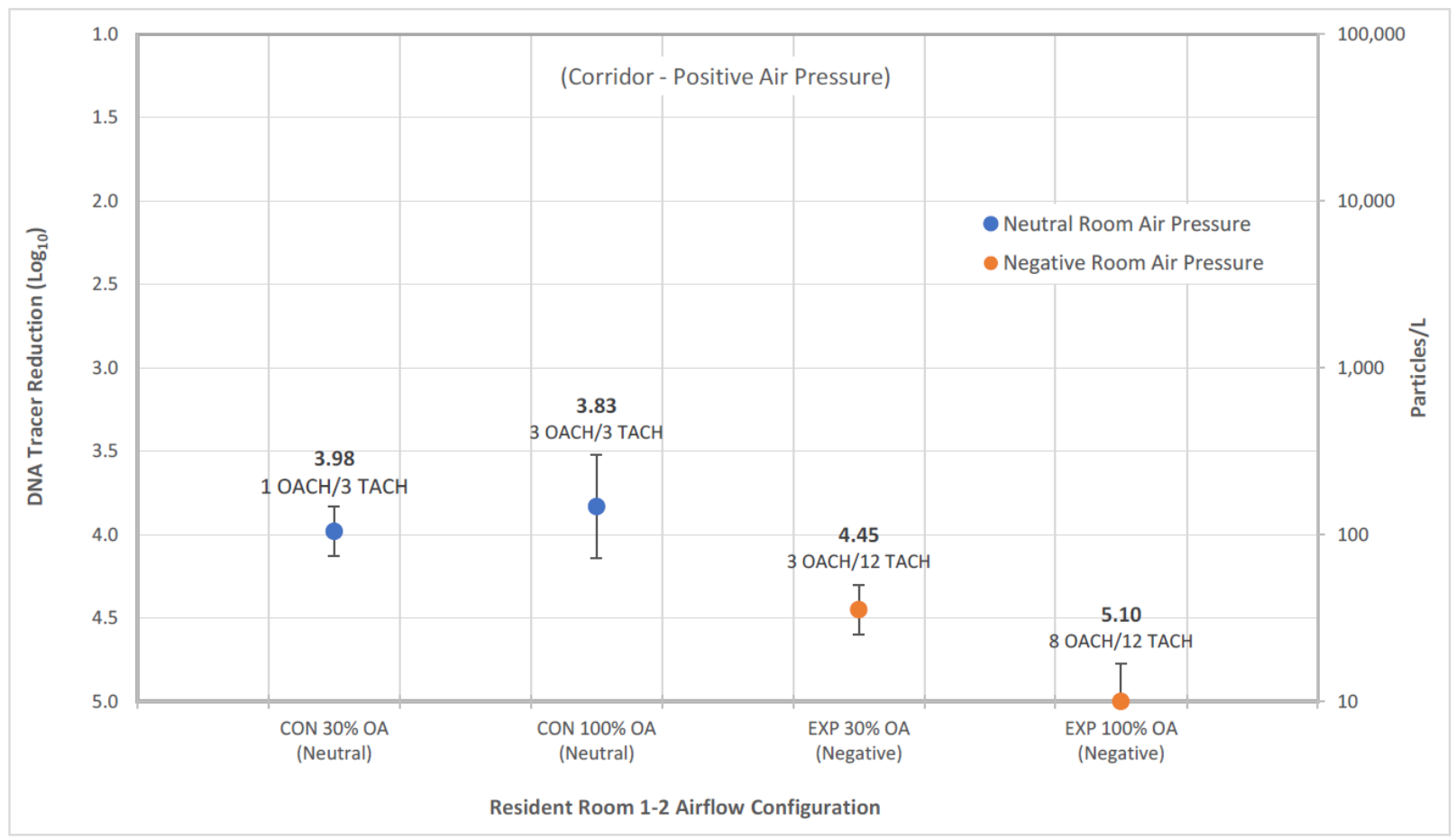

Figure 8. Corridor DNA tracer reduction $\log _{10}$ value and corresponding particle concentration $(\mathrm{p} / \mathrm{L})$ compared to resident room air change rate and directional airflow 


\subsubsection{Corridor Transmission to Resident Rooms}

To evaluate the effect of directional airflow on contaminant movement from the corridor to the resident rooms, DNA tracer aerosol was released in the corridor and sampled in resident rooms 1 and 2. For each test, tracer aerosol was released in the middle of the corridor. DNA tracer samples were then collected for 40 minutes at two locations in each resident room (Figure 9). Doors between resident rooms, anterooms, and the corridor remained closed during tests.

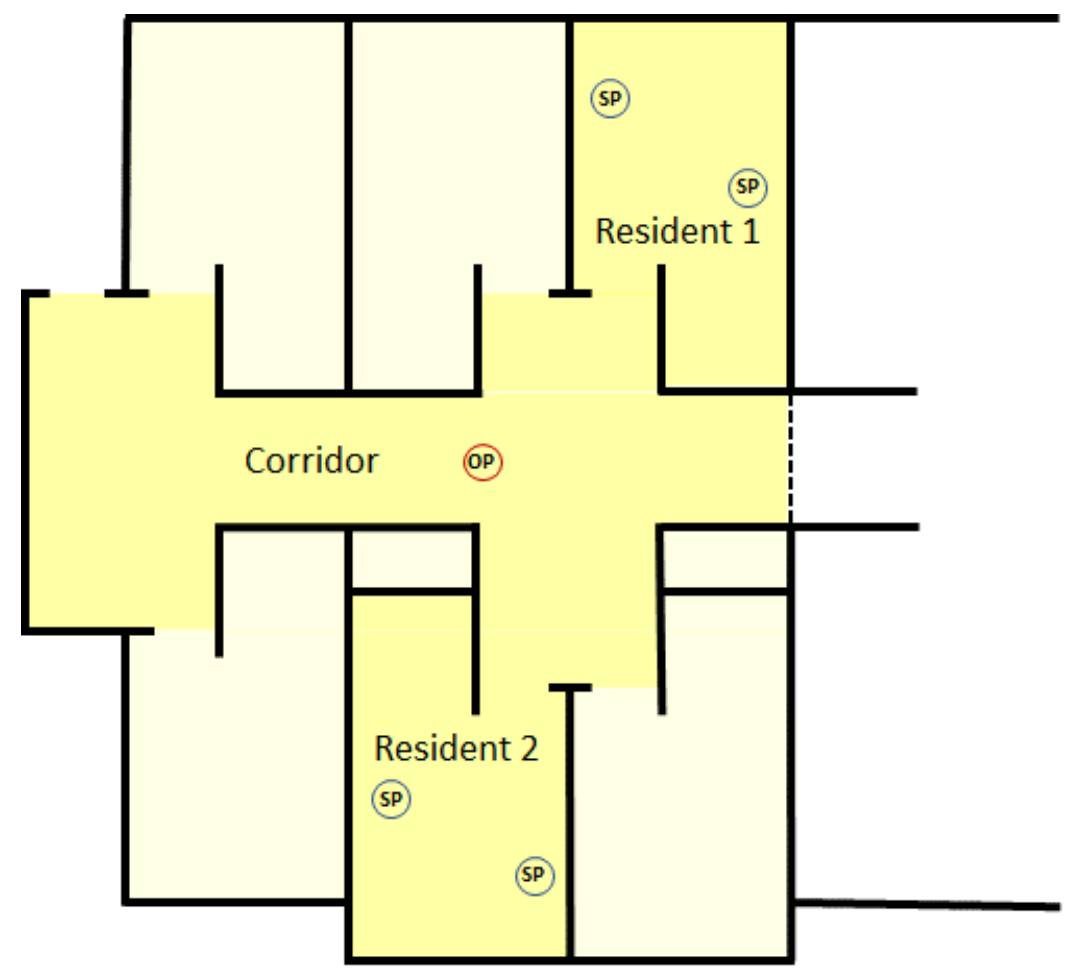

Figure 9. Corridor DNA tracer aerosol release and resident room sampling locations

Following PCR analyses of resident room samples, moderate increases in tracer aerosol movement from the corridor to the resident rooms were associated with directional airflow. With positive air pressure in the corridor and neutral air pressure in resident rooms, the average DNA tracer reduction $\log _{10}$ value in the resident rooms ranged between 2.85 to 3.13 , corresponding to a contaminant load of approximately 741 to $1,413 \mathrm{p} / \mathrm{L}$ (Figure 10). With positive air pressure in the corridor and negative air pressure in resident rooms, the average DNA tracer reduction $\log _{10}$ value in the resident rooms ranged between 2.30 to 2.50 , corresponding to a contaminant load of approximately 3,162 to $5,012 \mathrm{p} / \mathrm{L}$.

Overall, tracer aerosol movement from the corridor to the resident rooms was correlated to directional airflow $\left(r^{2}>0.82\right)$. In contrast, air change rates in resident rooms were not correlated to contaminant movement from the corridor to the resident rooms $\left(r^{2}<0.09\right)$. Working against directional airflow, room doors had less effect on the containment of airborne contaminants moving from the corridor to resident rooms. With resident room and anteroom doors closed, 
tracer aerosol movement from the corridor to the resident rooms was significantly greater in the negative airflow mode compared to the neutral airflow mode.

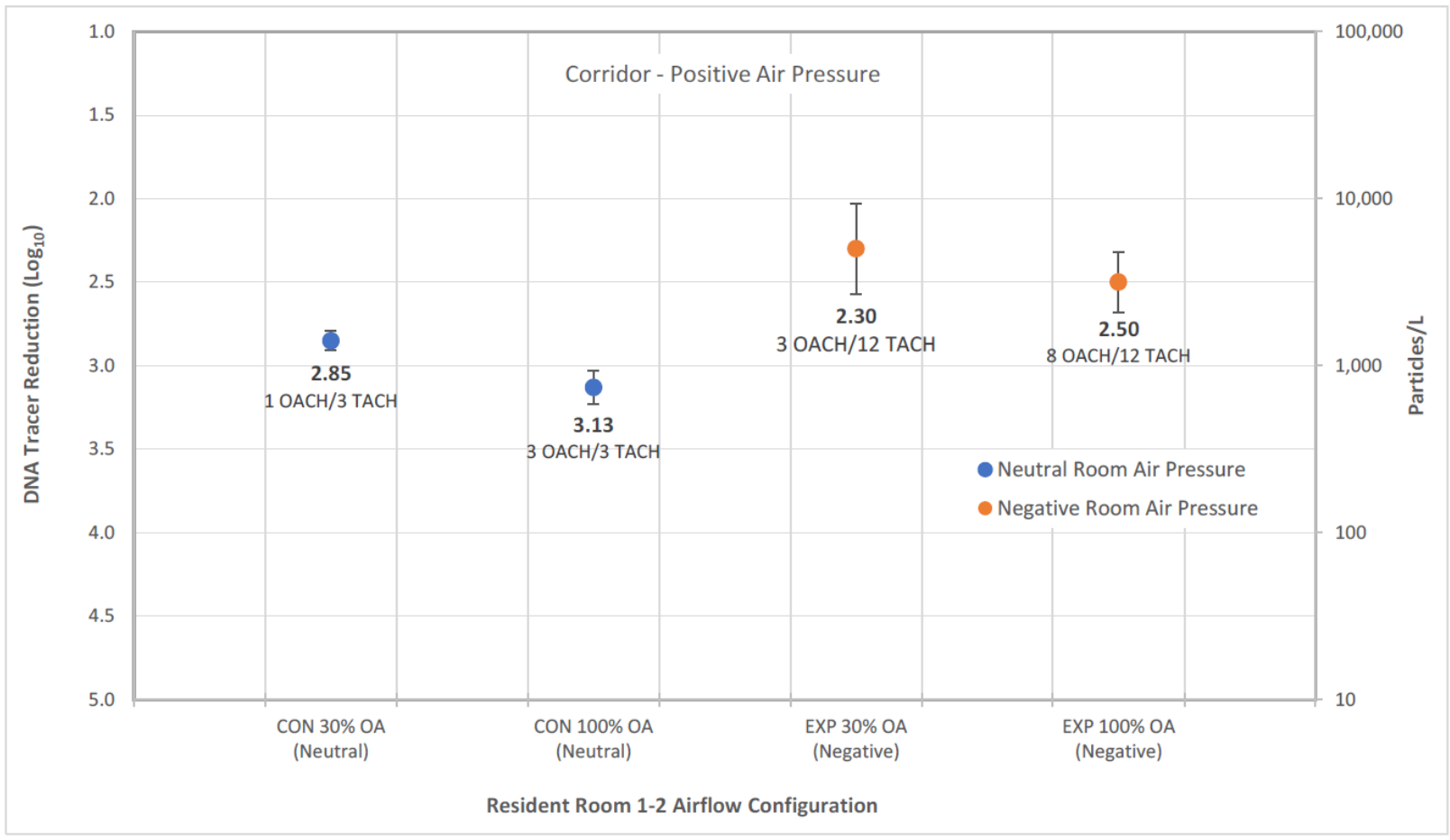

Figure 10. Resident room DNA tracer reduction $\log _{10}$ value and corresponding particle concentration (p/L) compared to resident room air change rate and directional airflow

\subsubsection{Resident Room Transmission to Staff Room}

To further assess exposure risks to healthcare workers, DNA tracer aerosol was released inside resident rooms 1 and 2 and sampled in the staff room. Again, tracer aerosol was released at the head of the resident room bed toward the opposite corner of the room at a height of $0.8 \mathrm{~m} \mathrm{(30} \mathrm{in.)}$ above the floor. DNA tracer samples were then collected for 40 minutes in the staff room at a height of $0.8 \mathrm{~m}$ (30 in.) above the floor (Figure 11). Doors between resident rooms and the staff room were closed during tests.

Following PCR analyses of staff room samples, moderate reductions in tracer aerosol movement from resident rooms to the staff room were associated with directional airflow. With positive air pressure in the corridor and neutral air pressure in the staff room and resident rooms, the average DNA tracer reduction $\log _{10}$ value in the staff room ranged between 3.75 and 4.05 , corresponding to a contaminant load of approximately 89 to $178 \mathrm{p} / \mathrm{L}$ (Figure 12). With positive air pressure in the staff room and corridor and negative air pressure in the resident rooms, the average DNA tracer reduction $\log _{10}$ value in the staff room ranged between 4.75 and 5.45 , corresponding to a contaminant load of approximately 4 to $18 \mathrm{p} / \mathrm{L}$. Overall, tracer aerosol movement from resident rooms to the staff room was correlated to directional airflow $\left(r^{2}>0.93\right)$. In contrast, outdoor air change rates and subsequent contaminant loads in resident rooms were weakly correlated to contaminant loads in the staff room $\left(r^{2}<0.51\right)$. For tracer aerosol released in the corridor, 
however, aerosol movement from the corridor to the staff room was significantly greater in the neutral airflow mode compared to the negative airflow mode $\left(r^{2}>0.99\right)$. With the staff room and resident rooms in the neutral airflow mode, the average DNA tracer reduction $\log _{10}$ value in the staff room ranged between 1.70 and 2.0, corresponding to a contaminant load of approximately 10,000 to $19,953 \mathrm{p} / \mathrm{L}$. With the staff room positive and resident rooms negative, the average DNA tracer reduction $\log _{10}$ value in the staff room ranged between 4.30 and 4.40 , corresponding to a contaminant load of approximately 40 to $50 \mathrm{p} / \mathrm{L}$.

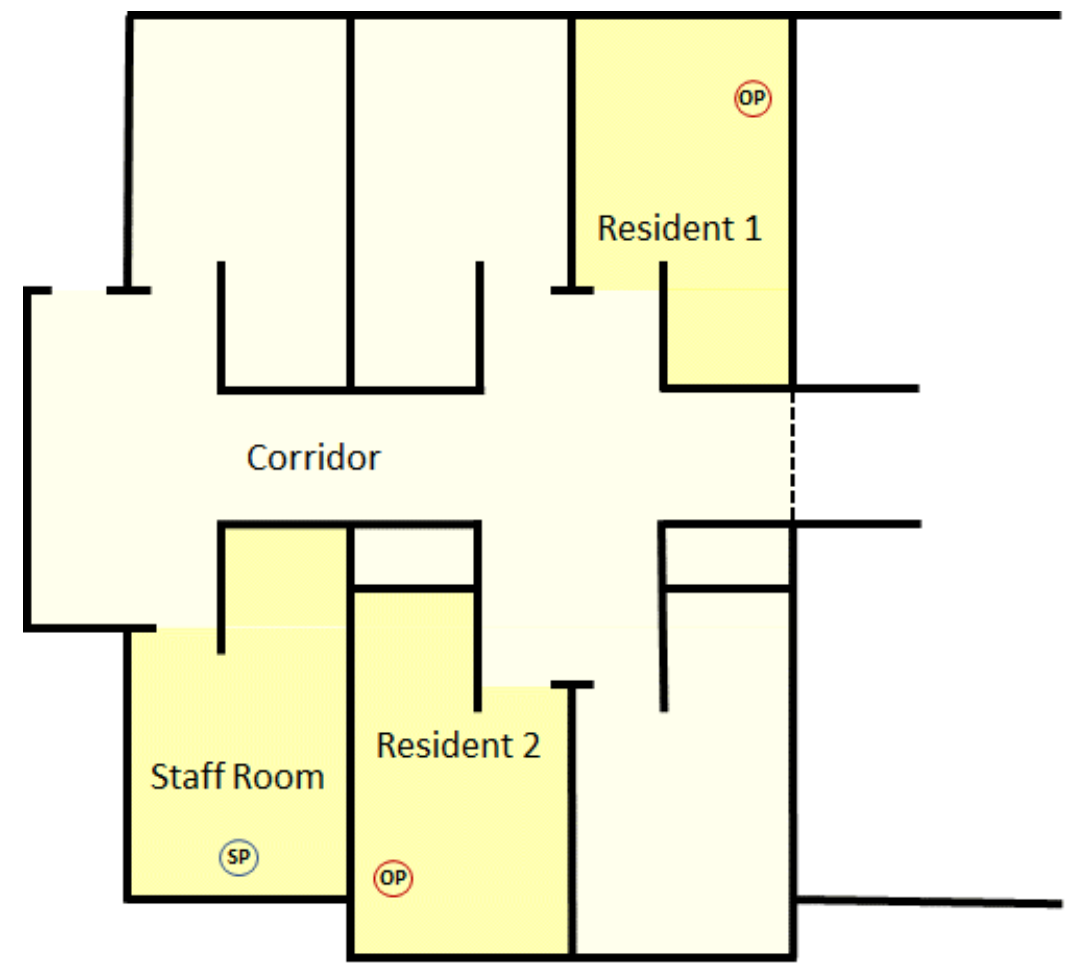

Figure 11. Resident room DNA tracer aerosol release and staff room sampling locations 


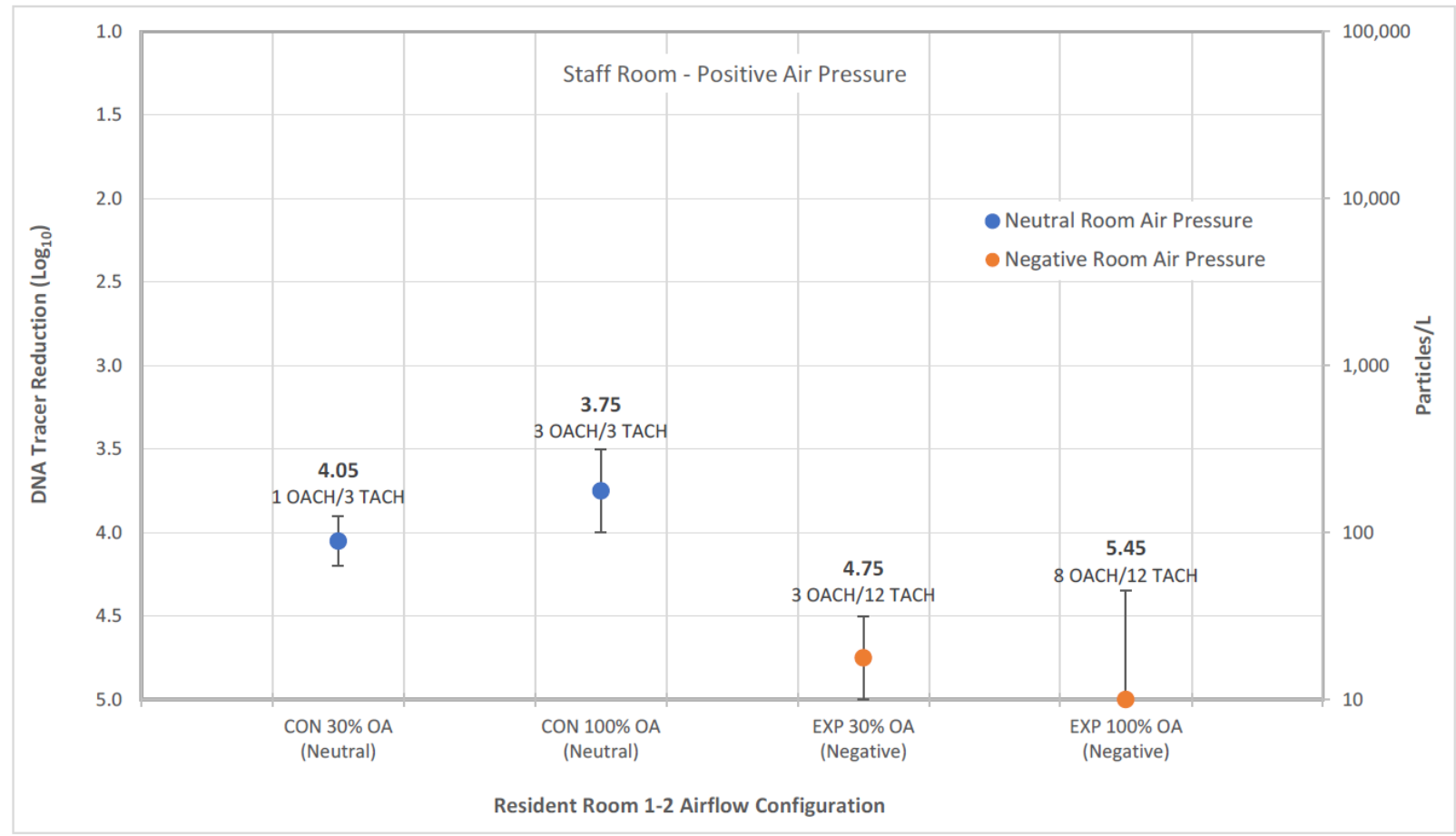

Figure 12. Staff room DNA tracer reduction $\log _{10}$ value and corresponding particle concentration $(\mathrm{p} / \mathrm{L})$ compared to resident room air change rate and directional airflow

\subsubsection{Isolation Zone Transmission to Common Areas}

To assess exposure risks to healthcare workers and residents outside of the isolation zone, DNA tracer aerosol was released inside resident rooms 1 and 2 and sampled in a nearby resident room, living room, and kitchen area. DNA tracer samples were collected for 40 minutes in each space at a height of $0.6-0.8 \mathrm{~m}(24-30 \mathrm{in}$.) above the floor (Figure 13). All doors within the isolation zone remained closed during tests as well as doors between the isolation zone and common areas. 


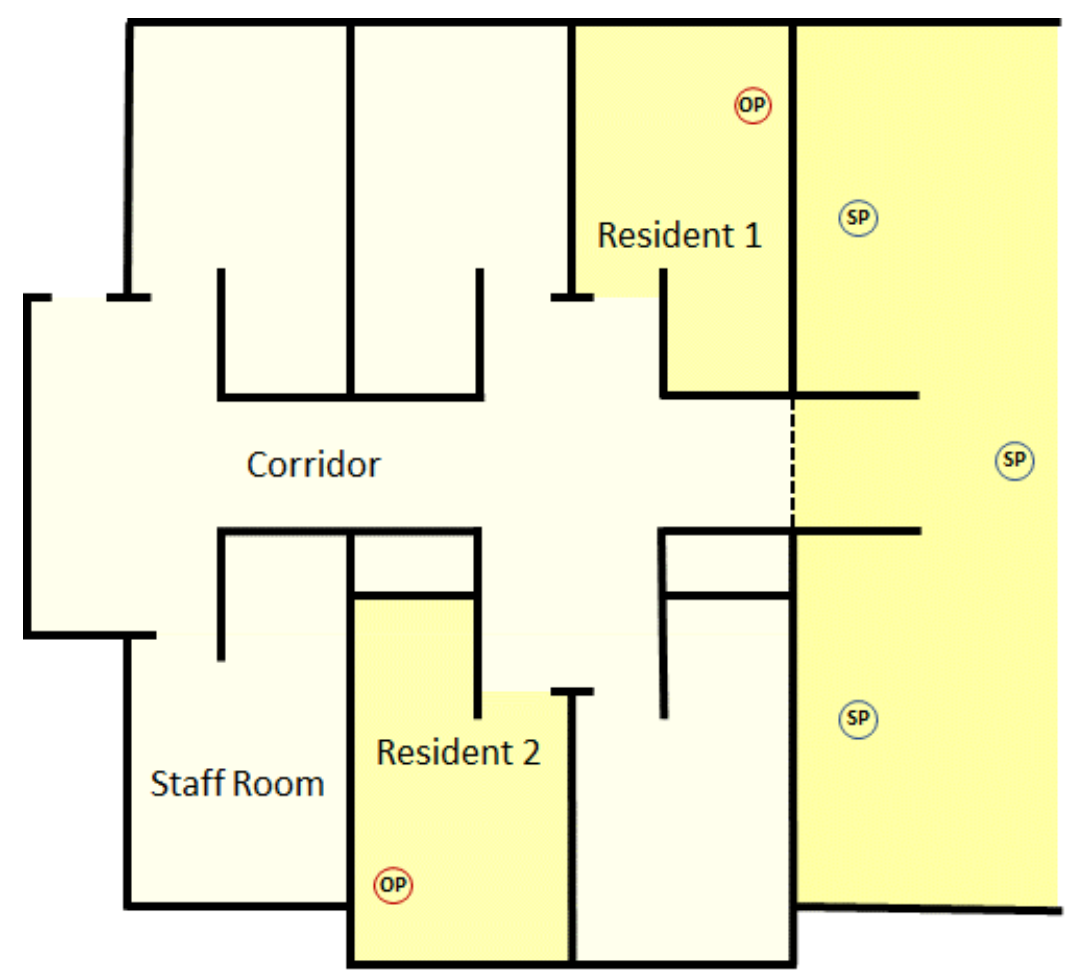

Figure 13. Resident room DNA tracer aerosol release and common areas sampling locations

Following PCR analyses of common area samples, reductions in tracer aerosol movement from resident rooms in the isolation zone to common areas outside of the isolation zone were not associated with directional airflow and only weakly associated with air change rates $\left(r^{2}>0.44\right)$. With positive air pressure in the corridor and neutral airflow in resident rooms, the average DNA tracer reduction $\log _{10}$ value in the areas outside of the isolation zone ranged between 4.55 and 4.90 , corresponding to a contaminant load of approximately 13 to $28 \mathrm{p} / \mathrm{L}$ (Figure 14). With positive air pressure in the corridor and negative airflow in resident rooms, the average DNA tracer reduction $\log _{10}$ value in areas outside of the isolation zone ranged between 4.35 and 5.38, corresponding to a contaminant load of approximately 4 to $45 \mathrm{p} / \mathrm{L}$.

For tracer aerosol released in the isolation zone corridor, however, aerosol movement from the corridor to areas outside of the isolation zone were marginally associated with directional airflow $\left(r^{2}>0.51\right)$ and moderately associated with air change rates $\left(r^{2}>0.75\right)$. With resident rooms in the neutral airflow mode, the average DNA tracer reduction $\log _{10}$ value outside of the isolation zone ranged between 3.70 and 4.10, corresponding to a contaminant load of approximately 79 to 200 $\mathrm{p} / \mathrm{L}$. With resident rooms in the negative airflow mode, the average DNA tracer reduction $\log _{10}$ value in areas outside of the isolation zone ranged between 4.20 and 5.30, corresponding to a contaminant load of approximately 5 to $63 \mathrm{p} / \mathrm{L}$. 


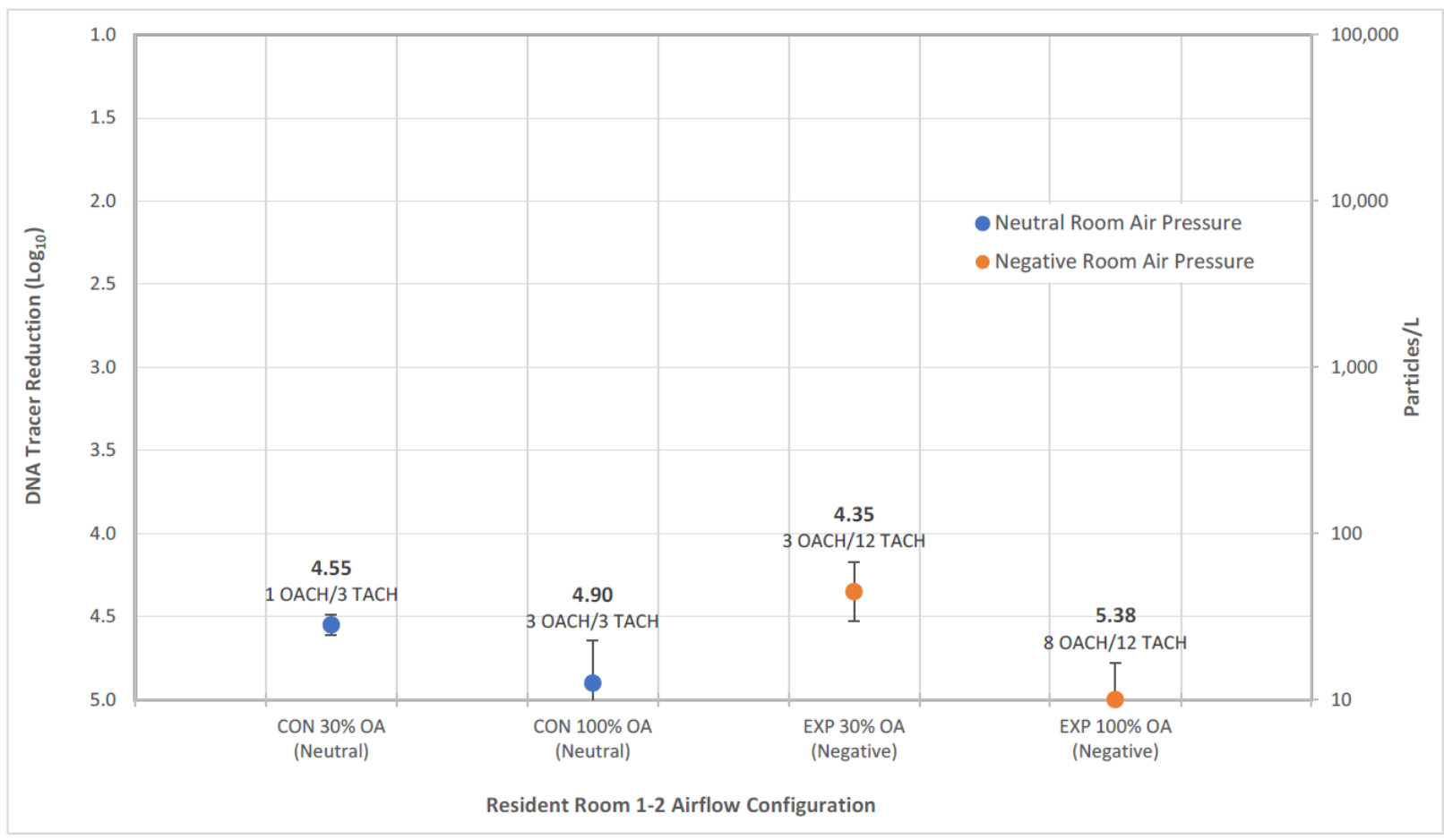

Figure 14. Common areas DNA tracer reduction $\log _{10}$ value and corresponding particle concentration (p/L) compared to resident room air change rate and directional airflow

\subsubsection{Isolation Zone Transmission to HVAC Systems}

DNA tracer samples were also collected at two locations inside of the HVAC system serving both the isolation zone and common spaces outside of the isolation zone. Tracer samples were collected for 40 minutes in the return air duct immediately upstream of the MERV 14 air filter (Figure 15) and in the supply air duct immediately downstream of the air filter (Figure 17). Of note, resident rooms in the negative airflow mode were equipped with HEPA filtration fan units at the return air location. Resident rooms in the neutral airflow mode were not equipped with HEPA filtration.

Following PCR analyses of return air samples, moderate contaminant load reductions were associated with increasing ventilation rates. Specifically, increasing ventilation rates from 1 to 3 $\mathrm{OACH}$ increased the average DNA tracer reduction $\log _{10}$ value from 4.0 to 4.20 , corresponding to a contaminant load reduction from 100 to $63 \mathrm{p} / \mathrm{L}$ (Figure 16). Adding HEPA return air filtration and increasing ventilation rates from 3 to $8 \mathrm{OACH}$ further increased the average DNA tracer reduction $\log _{10}$ value from 4.20 to 5.0 , corresponding to an additional contaminant load reduction from 63 to $10 \mathrm{p} / \mathrm{L}$. Overall, contaminant load reductions within HVAC return air were strongly correlated to outdoor air change rates $\left(r^{2}>0.96\right)$ and likely, the effect outdoor air change rates had on resident room contaminant loads.

Following analyses of supply air samples, no significant changes in contaminant loads were observed with respect to either directional airflow or ventilation rates in resident rooms (Figure 18). For supply air consisting of $100 \%$ outdoor air, no contaminants should be present unless 
exhaust air from the isolation zone inadvertently mixed with ventilation air. For supply air consisting of $30 \%$ outdoor air, dilution and MERV 14 filtration appeared to have reduced contaminant loads to near-negligible levels.

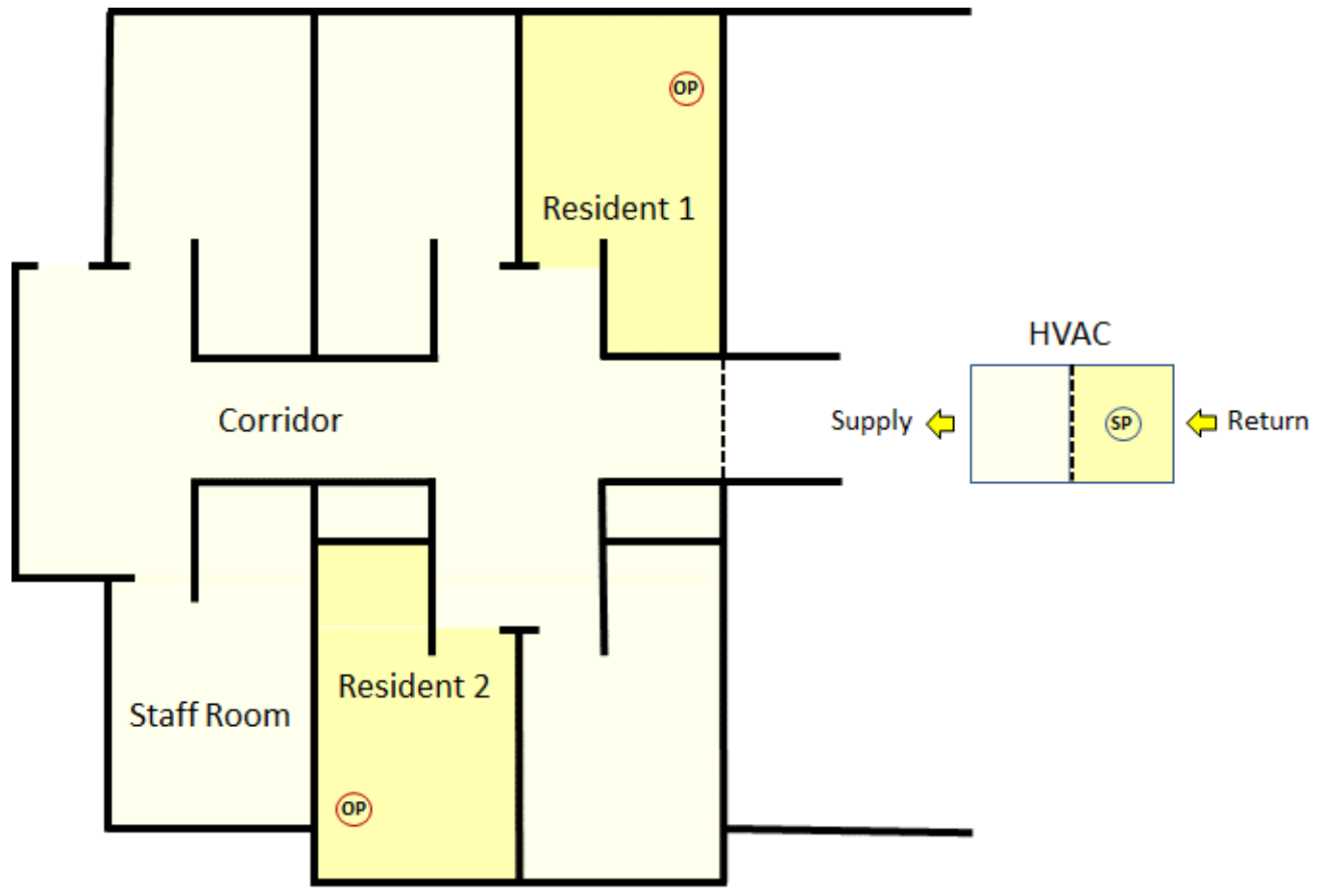

Figure 15. Resident room DNA tracer aerosol release and HVAC return air sampling locations

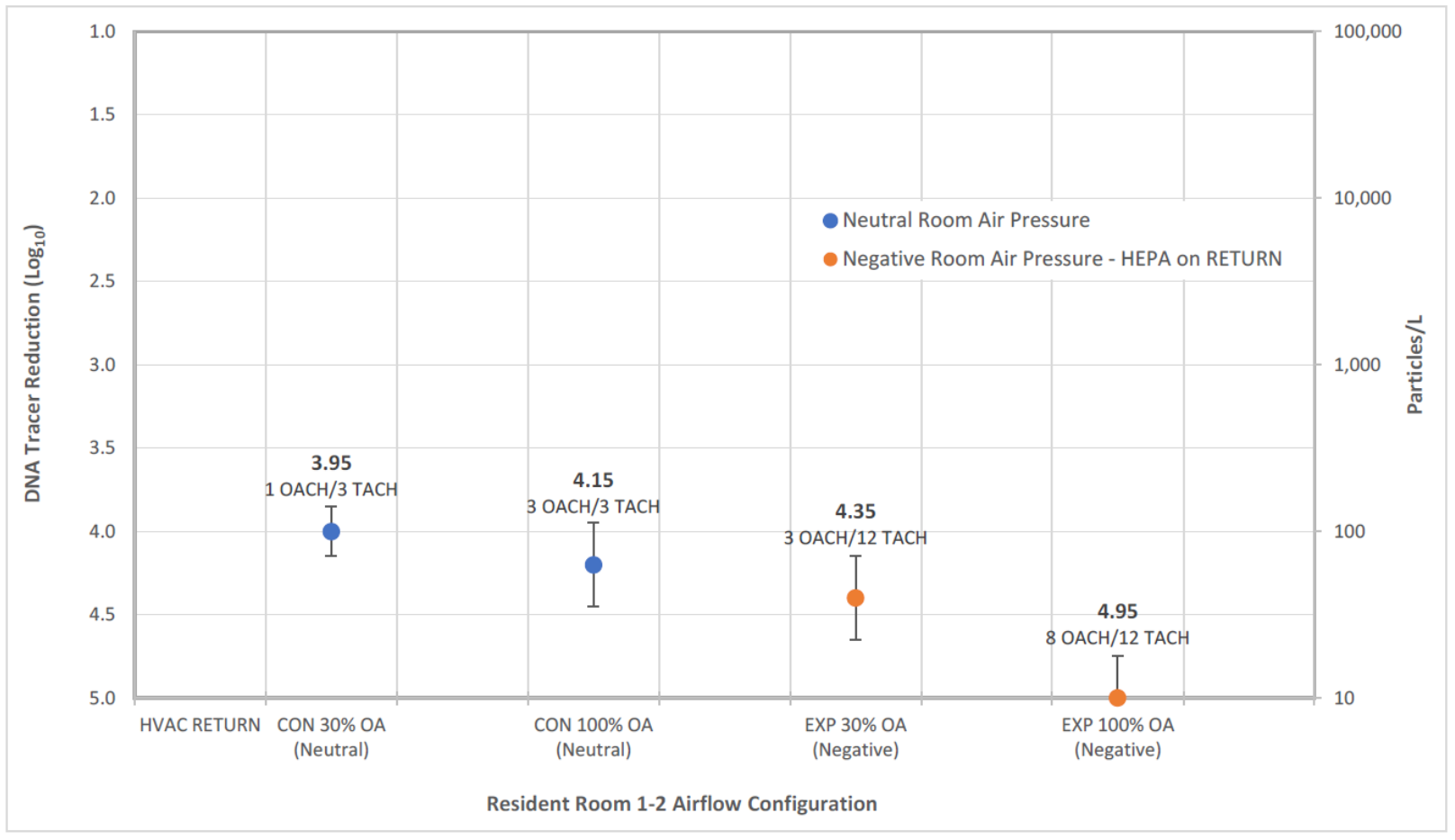

Figure 16. HVAC return air DNA tracer reduction $\log _{10}$ value and corresponding particle concentration (p/L) compared to resident room air change rate and directional airflow 


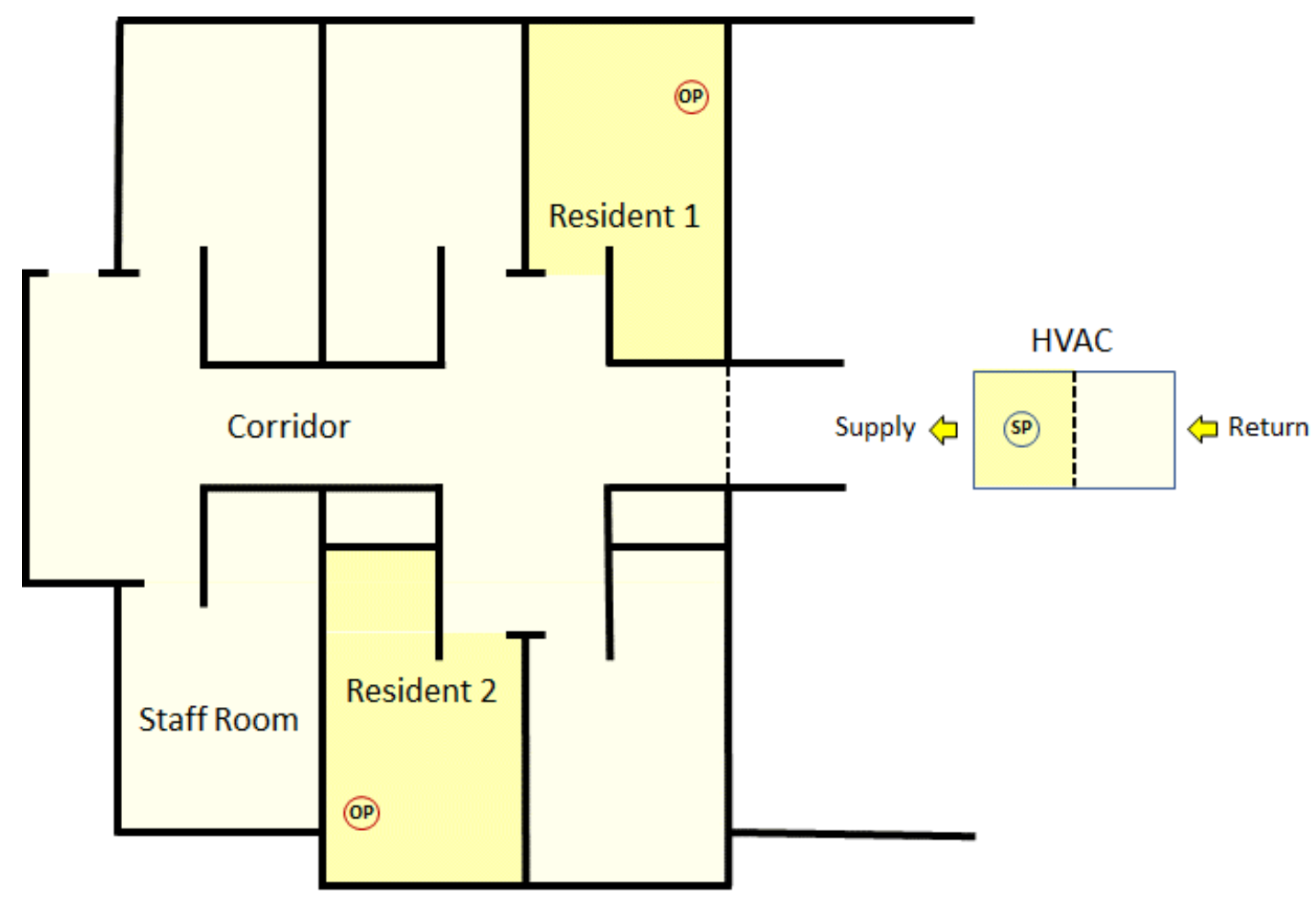

Figure 17. Resident room DNA tracer aerosol release and HVAC supply air sampling locations

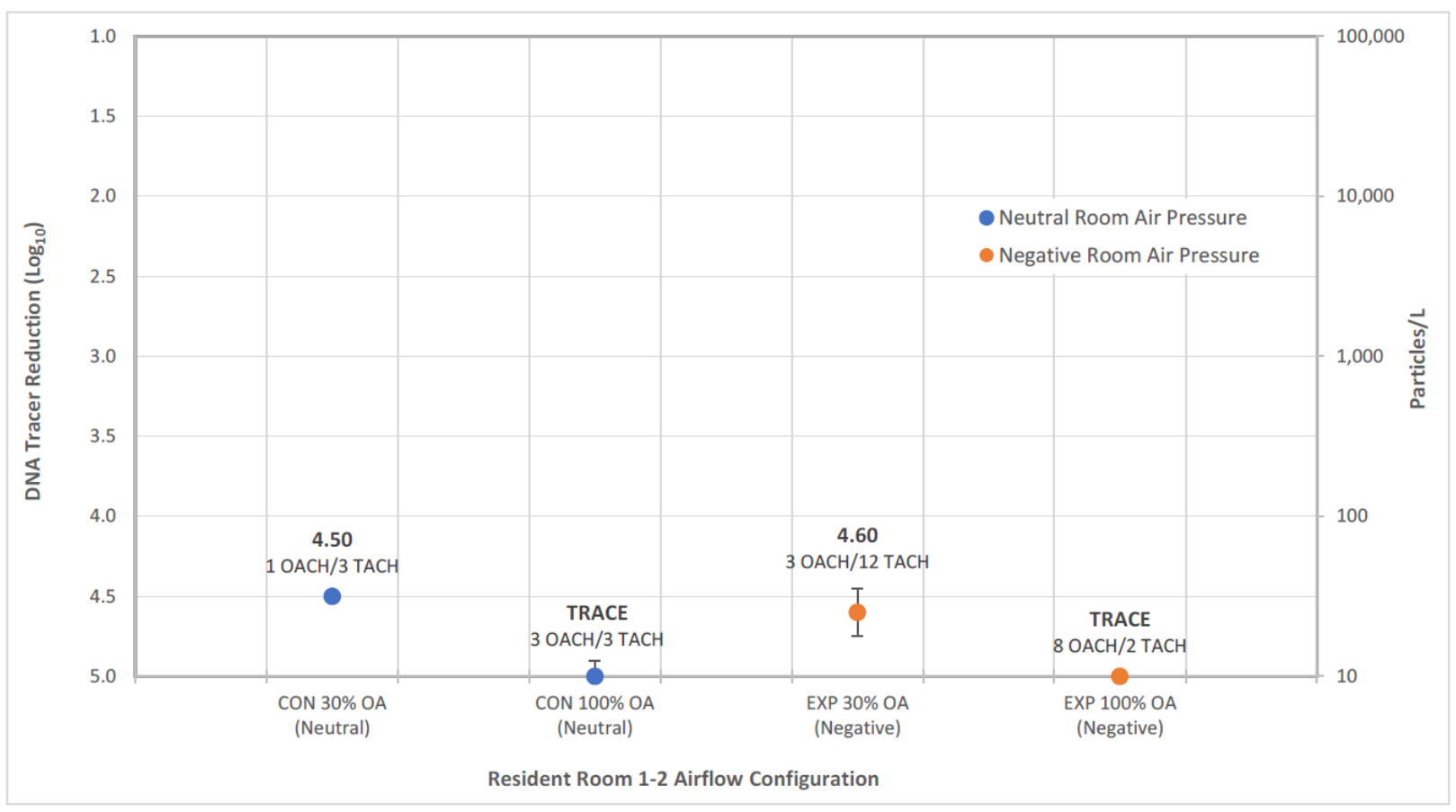

Figure 18. HVAC supply air DNA tracer reduction $\log _{10}$ value and corresponding particle concentration (p/L) compared to resident room air change rate and directional airflow 


\subsubsection{Room Recovery}

Two additional tests were conducted to evaluate the effect of ventilation rates on room recovery, or the reduction in contaminant load over time in communal spaces such as exercise rooms and dining areas. One test was conducted at $1 \mathrm{OACH}(100 \mathrm{cfm})$ and another was conducted at 6 $\mathrm{OACH}(650 \mathrm{cfm})$ in a $750 \mathrm{ft}^{2}(6,300 \mathrm{cf})$ exercise room (Figure 19) located outside of the isolation zone. The duration of each test was 40 minutes and utilized two DNA tracer aerosol release points and two air sampling locations. Each sampling location consisted of four air samplers to record the decay of tracer aerosol at 10-minute intervals over the 40-minute test sequence.

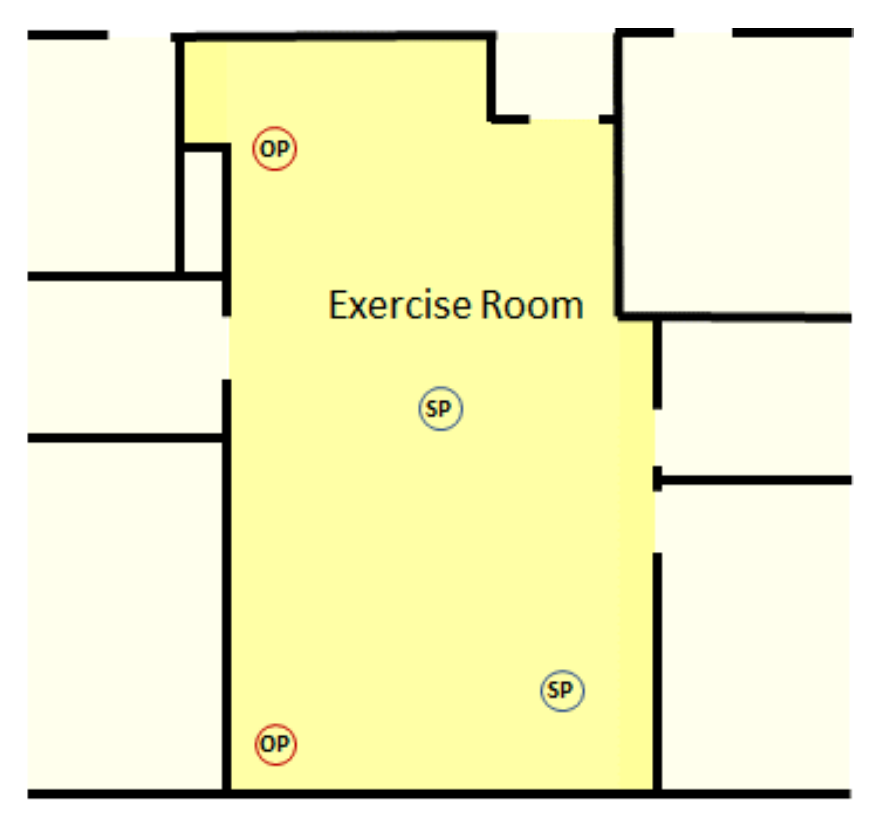

Figure 19. Exercise room DNA tracer aerosol release and sampling locations

Following PCR analyses of exercise room samples, significant contaminant load reductions were associated with increasing ventilation rates. Specifically, increasing ventilation rates from 1 to 6 $\mathrm{OACH}$ increased the average DNA tracer reduction $\log _{10}$ value from 2.0 to 2.40 after 10 minutes, corresponding to a contaminant load reduction from 10,000 to 3,981 p/L (Figure 20). Increasing ventilation rates from 1 to $6 \mathrm{OACH}$ further increased the average DNA tracer reduction $\log _{10}$ value from 3.35 to 4.75 after 40 minutes, corresponding to a contaminant load reduction from 447 to $18 \mathrm{p} / \mathrm{L}$. On average, the contaminant decay rate at $6 \mathrm{OACH}$ was more than twice the decay rate at $1 \mathrm{OACH}$. At $6 \mathrm{OACH}$, a $99.0 \%$ contaminant load reduction (i.e., "removal efficiency") is achieved after 40 minutes compared to a $90.0 \%$ contaminant load reduction at 1 $\mathrm{OACH}$. By comparison, a $99.0 \%$ removal efficiency at $1 \mathrm{OACH}$ would require approximately $3-$ 4 hours. 
Ventilation in Residential Care Environments

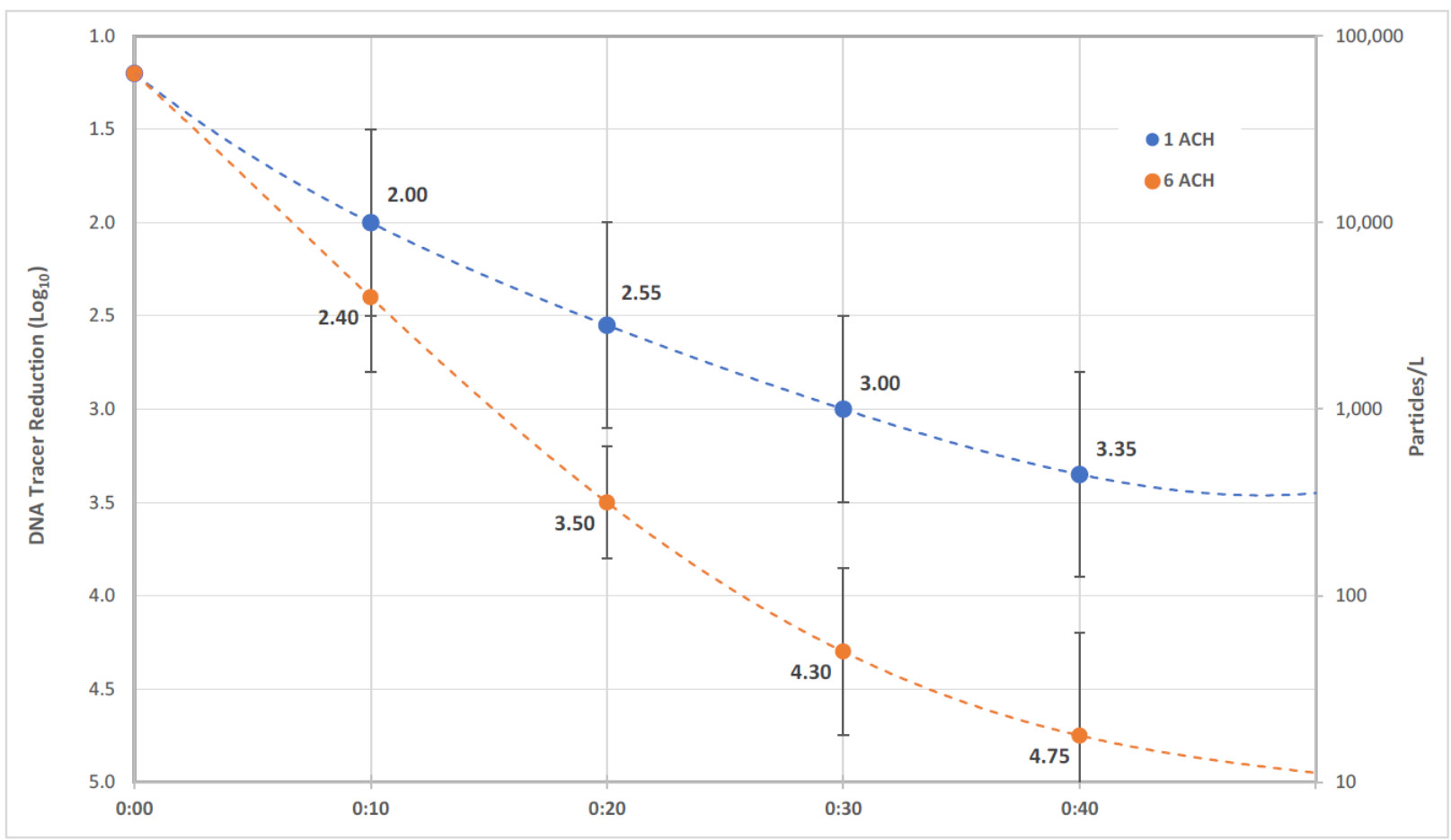

Figure 20. Exercise room DNA tracer reduction $\log _{10}$ value and corresponding particle concentration $(p / L)$ compared to air change rate 


\section{Conclusions}

Results suggest ventilation rates had a modest effect on contaminant loads and exposure risks within resident rooms. Increasing air change rates from 1 to $8 \mathrm{OACH}$, for example, reduced the contaminant load and potential exposure risk to healthcare workers from an infectious occupant by roughly half $(43.8 \%)$ from $7.1 \times 10^{3} \mathrm{p} / \mathrm{L}$ to $3.9 \times 10^{3} \mathrm{p} / \mathrm{L}$. This finding was consistent with results from other similar studies that found air change rates were not effective in proportionately reducing aerosol concentrations within hospital patient rooms. In one such ASHRAE study, increasing air change rates from two to five $\mathrm{ACH}$ reduced concentrations of aerosols less than $5 \mu \mathrm{m}$ by only $30 \%$ on average (Grosskopf and Mousavi 2014).

Under the assumption of a well-mixed space, it can be shown that contaminants decay exponentially in time. In spaces with recirculated air (e.g., less than $100 \%$ outside air), the decay rate can be expressed as a function of the air change rate:

$$
C(t)=C_{0} e^{A C H \times[(1-\alpha) \times(1-\eta)-1] \times t}
$$

where,

$C_{0}$ is the initial contaminant load

$C(t)$ is the contaminant load as a function of time

$\alpha$ is the outside air percentage

$\eta$ is the filtration efficiency.

In spaces with $100 \%$ outside air (or 100\% filter efficiency), the decay rate can be simplified as:

$$
C(t)=C_{0} e^{-A C H \times t}
$$

It would therefore be expected that contaminant loads observed in resident rooms would correspond proportionately to air change rates, and specifically, outdoor air change rates. Results suggest that resident room contaminant loads did not correspond proportionately to air change rates. Possible explanations include the likelihood that the resident rooms are not well mixed, suggesting that areas of the room between the supply air and the exhaust air may receive more air changes whereas areas of the room obstructed by partitions or furnishings may receive fewer air changes. Other explanations may include the effects of air turbulence, particularly at higher air change rates. Air turbulence may impede other contaminant removal mechanisms such as surface deposition and gravitational settling. Vortices created by turbulence may further "trap" and suspend contaminants in room air currents, preventing their effective removal. 
Similarly, ventilation rates had a modest effect on contaminant loads in HVAC systems. Increasing air change rates from 1 to $8 \mathrm{OACH}$ and adding HEPA return air filtration reduced the contaminant load in the return air from 100 to $10 \mathrm{p} / \mathrm{L}$. In relation to resident room contaminant loads however, contaminant loads in the return air were very low regardless of air change rate or filtration. Ventilation rates, however, were found to have a significant effect on contaminant loads and exposure risks in common areas. Increasing air change rates from 1 to $6 \mathrm{OACH}$ reduced the time required to achieve "room recovery," or the removal of $99 \%$ of contaminants, from 3 hours to less than 40 minutes once the infectious source was removed.

Directional airflow was found to have a significant effect on contaminant mobility from resident rooms to adjacent spaces. Contaminant movement from negative-pressure resident rooms to the corridor was on average $10-35 \mathrm{p} / \mathrm{L},<20 \%$ of the contaminant movement observed from neutral pressure rooms to the corridor $(105-148 \mathrm{p} / \mathrm{L})$. Similarly, contaminant movement from the negative pressure resident room to the positive pressure staff room was on average $4-18 \mathrm{p} / \mathrm{L}$, less than $10 \%$ the contaminant movement observed from the neutral pressure resident room to the neutral pressure staff room $(89-178$ p/L). Little difference, however, was observed in contaminant movement from either neutral or negative-pressure resident rooms in the isolation zone to the common areas outside of the isolation zone. This finding suggests that while closed, resident room doors likely had a greater effect on contaminant movement than directional airflow.

Under normal operational conditions, however, with healthcare workers entering and exiting resident rooms, the effects of directional airflow would likely have been more evident. In fact, door position, door motion, and healthcare worker movement have been implicated in the transmission of airborne disease in several epidemiological studies dating back more than 40 years (Leclair et al. 1980; Gustafson et al. 1982; Josephson and Gombert 1988; Edlin et al. 1992; Tang et al. 2005; Beggs et al. 2008; Eames et al. 2009; Mousavi and Grosskopf 2016). Analysis of the door opening motion in these and other studies suggests that directional airflow relationships between isolation and adjacent healthcare spaces can be terminated and even reversed by door position, door motion, and healthcare worker movement.

Overall, contaminant loads observed in spaces outside of resident rooms were on average two to three orders of magnitude less than the contaminant loads observed inside of the resident rooms, suggesting the effectiveness of both physical airflow barriers and directional airflow to limit bioaerosol mobility within temporary isolation spaces and between isolation spaces and the LTC environment. 


\section{References}

Abrams, H., L. Loomer, A. Ghandi, and D. Grabowski. 2020. Characteristics of U.S. Nursing Homes with COVID-19 Cases. Journal of the American Geriatrics Society 68(8), 1619-1886.

ASHRAE. 2020. “ASHRAE Epidemic Task Force: Scientific Data Committee." https://www.ashrae.org/file\%20library/technical\%20resources/covid-19/ashrae-scientific-c19guidance.pdf.

Anderson, E., P. Turnham, J. Griffin, and C. Clarke. 2020. Consideration of the Aerosol Transmission for COVID-19 and Public Health. Risk Analysis 40(5), 902-907.

ANSI/ASHRAE/ASHE Standard 170-2013, Ventilation of Healthcare Facilities. Accessed February 16, 2021. https://www.ashrae.org/technical-resources/standards-andguidelines/standards-addenda/ansi-ashrae-ashe-standard-170-2017-ventilation-of-health-carefacilities.

Arons, M., K. Hatfield, S. Reddy, A. Kimball, A. James, J. Jacobs, J. Taylor, K. Spicer, A. Bardossy, L. Oakley, S. Tanwar, J. Dyal. 2020. Presymptomatic SARS-CoV-2 Infections and Transmission in a Skilled Nursing Facility. New England Journal of Medicine 382, 2081-2090.

ASHE. 2020. Temporary Negative Pressure Patient Room Options. Accessed February 16, 2021. https://www.ashe.org/negative-pressure-rooms.

ASHRAE. 2020. "Position Document on Infectious Aerosols.” Accessed February 16, 2021. https://www.ashrae.org/file\%20library/about/position\%20documents/pd infectiousaerosols_202 0.pdf.

Blackman, C., S. Farber, R. Feifer, V. Mor, and E. White. 2020. An Illustration of SARS-CoV-2 Dissemination Within a Skilled Nursing Facility Using Heat Maps. Journal of the American Geriatrics Society 68(10), 2174-2178.

Centers for Disease Control National Center for Health Statistics. 2016. "Nursing Home Care." Accessed February 16, 2021. https:/www.cdc.gov/nchs/fastats/nursing-home-care.htm.

Centers for Medicare \& Medicaid Services. 2020. “COVID-19 Nursing Home Data.” Accessed February 16, 2021. https://data.cms.gov/stories/s/COVID-19-Nursing-Home-Data/bkwz-xpvg.

Diaz-Decaro, J., B. Launer, J. Mckinnell, R. Singh, T. Dutciuc, N. Green, M. Bolaris, S. Huang, and L. Miller. 2018. Bayesian evidence and epidemiological implications of environmental contamination from acute respiratory infection in long-term care facilities. Epidemiology and Infection 146(7), 832-838.

Gorbunov, B. 2020. Aerosol particles laden with COVID-19 travel over 30m distance. Canterbury, Kent, United Kingdom: Ancon Technologies.

https://www.ancontechnologies.com/wp-content/uploads/Dr-Gorbunov-Covid-19-aerosoldiffusion.pdf. 
Grosskopf, K. and E. Mousavi. 2014. Ventilation and the Transport of Bioaerosols in Healthcare Environments. ASHRAE Journal 56(8).

Kimball, A., K. Hatfield, M. Arons et al. March 2020. Asymptomatic and Presymptomatic SARS-CoV-2 Infections in Residents of a Long-Term Care Skilled Nursing Facility. Morbidity and Mortality Weekly Report (CDC) 69, 377-381.

Lynch, R. and R. Goring. 2020. Practical steps to improve air flow in long-term care resident rooms to reduce COVID-19 infection risk. Journal of Post-Acute and Long-Term Care Medicine 21(7), 893-894.

Miller, S., D. Mukherjee, J. Wilson, N. Clements, and C. Steiner. 2020. Implementing a negative pressure isolation space within a skilled nursing facility to control SARS-CoV-2 transmission. American Journal of Infection Control.

Montoya, A. and A. Lody. 2011. Common infections in nursing homes: a review of current issues and challenges. Aging Health 7(6), 889-899.

Morawska, L. et al. 2020. How can airborne transmission of COVID-19 indoors be minimised? Environment International 142, 105832.

Mousavi, E. and K. Grosskopf. 2016. Airflow patterns due to door motion and pressurization in hospital isolation rooms. Science and Technology for the Built Environment 22(4), 379-384.

National Air Filtration Association. 2020. "COVID-19 (Corona Virus) and Air Filtration Frequently Asked Questions (FAQs).” Accessed February 17, 2021. https://www.nafahq.org/covid-19-corona-virus-and-air-filtration-frequently-asked-questionsfaqs/.

Schoen, L. 2020. Guidance for Building Operations During the COVID-19 Pandemic. ASHRAE Journal 62(5), 72-74.

World Health Organization. 2020. "Transmission of SARS-CoV-2: implications for infection prevention precautions.” July 9, 2020. Accessed February 17, 2021. https:/www.who.int/newsroom/commentaries/detail/transmission-of-sars-cov-2-implications-for-infection-preventionprecautions.

Wiberg, D. "COVID-19 in the built environment."

Zhao, B., Y. Liu, and C. Chen. 2020. Air purifiers: a supplementary measure to remove airborne SARS-CoV-2. Building and Environment 177, 106918. 


\section{Appendix A. Annotated Bibliography}

Tables A-1 to A-3 include resources from the ASHRAE Epidemic Task Force Scientific Data Committee (ASHRAE 2020).

\section{Table A-1. Skilled Nursing Facilities-COVID-19 (All Resources Date from 2020)}

\begin{tabular}{|c|c|c|}
\hline Author & Article Title & Summary/Relevant Excerpts \\
\hline $\begin{array}{l}\text { Abrams, Hannah R. } \\
\text { et al. }\end{array}$ & $\begin{array}{l}\text { Characteristics of U.S. Nursing Homes with } \\
\text { COVID-19 Cases. Journal of the American } \\
\text { Geriatrics Society. }\end{array}$ & $\begin{array}{l}\text { Of 9,395 nursing homes in our sample, 2,949 ( } 31.4 \%) \text { had a documented COVID- } \\
19 \text { case. Larger facility size, urban location, greater percentage of African } \\
\text { American residents, non-chain status, and state were significantly ( } p<.05) \\
\text { related to the increased probability of having a COVID-19 case. Five-star rating, } \\
\text { prior infection violation, Medicaid dependency, and ownership were not } \\
\text { significantly related. }\end{array}$ \\
\hline Arons, M. M. et al. & $\begin{array}{l}\text { Presymptomatic SARS-CoV-2 Infections } \\
\text { and Transmission in a Skilled Nursing } \\
\text { Facility. New England Journal of Medicine. }\end{array}$ & $\begin{array}{l}\text { SARS-CoV- } 2 \text { infection can spread rapidly within skilled nursing facilities. After } \\
\text { identification of a case of COVID-19 in a skilled nursing facility, we assessed } \\
\text { transmission and evaluated the adequacy of symptom-based screening to } \\
\text { identify infections in residents. Twenty-three days after the first positive test } \\
\text { result in a resident at this skilled nursing facility, } 57 \text { of } 89 \text { residents ( } 64 \% \text { ) tested } \\
\text { positive for SARS-CoV- } 2.56 \% \text { were asymptomatic at the time of testing; } 24 \\
\text { subsequently developed symptoms (median time to onset, } 4 \text { days). Samples from } \\
\text { these } 24 \text { presymptomatic residents had a median rRT-PCR cycle threshold value } \\
\text { of } 23.1 \text {, and viable virus was recovered from } 17 \text { residents. As of April } 3 \text {, of the } 57 \\
\text { residents with SARS-CoV- } 2 \text { infection, } 11 \text { had been hospitalized ( } 3 \text { in the intensive } \\
\text { care unit) and } 15 \text { had died (mortality } 26 \% \text { ). }\end{array}$ \\
\hline Blackman, Carolyn et al. & $\begin{array}{l}\text { An Illustration of SARS-CoV-2 } \\
\text { Dissemination Within a Skilled Nursing } \\
\text { Facility Using Heat Maps. Journal of the } \\
\text { American Geriatrics Society. }\end{array}$ & $\begin{array}{l}\text { To illustrate dissemination and asymptomatic transmission of SARS-CoV-2 during } \\
\text { an outbreak at a 150-bed skilled nursing facility (SNF), heat maps were generated } \\
\text { by the SNF's infection prevention team to track staff and resident symptoms and } \\
\text { SARS-CoV-2 test results to identify infection patterns. The SNF experienced a } \\
\text { severe outbreak of SARS-CoV-2 early in the pandemic. The initial cluster of } \\
\text { residents with symptoms and the first confirmed case occurred on the SNF's }\end{array}$ \\
\hline
\end{tabular}




\begin{tabular}{|c|c|c|}
\hline & & $\begin{array}{l}\text { dementia care unit. The insufficient availability and prolonged turnaround time } \\
\text { of testing for both residents and staff at the outset of the outbreak prevented } \\
\text { timely and accurate identification and cohorting of cases. Despite extensive other } \\
\text { infection control measures being in place, SARS-CoV- } 2 \text { disseminated widely } \\
\text { through the facility within three weeks of the first confirmed case, resulting in } \\
\text { significant morbidity and mortality. }\end{array}$ \\
\hline $\begin{array}{l}\text { Centers for Medicare \& } \\
\text { Medicaid Services }\end{array}$ & $\begin{array}{l}\text { COVID-19 Nursing Home Data (9/20). } \\
\text { https://data.cms.gov/. }\end{array}$ & $\begin{array}{l}\text { Total COVID-19 confirmed nursing home cases: } 238,283(3.5 \%) \text {. Total COVID-19 } \\
\text { confirmed nursing home deaths: } 57,008 \text { (29.8\%). U.S. total: } 6,770,820 \text { cases; } \\
\text { 191,627 deaths. }\end{array}$ \\
\hline CDC & $\begin{array}{l}\text { Nursing Home Care. National Center for } \\
\text { Health Statistics. } \\
\text { https://www.cdc.gov/nchs/fastats/nursing } \\
\text {-home-care.htm. }\end{array}$ & $\begin{array}{l}\text { Number of nursing homes: 15,600 (2016). Number of beds: } 1.7 \text { million (2016). } \\
\text { Number of residents: } 1.3 \text { million (2015). }\end{array}$ \\
\hline de Man, Peter et al. & $\begin{array}{l}\text { Outbreak of COVID-19 in a nursing home } \\
\text { associated with aerosol transmission as a } \\
\text { result of inadequate ventilation. Clinical } \\
\text { Infectious Diseases. }\end{array}$ & $\begin{array}{l}\text { Data suggest that this outbreak is caused by aerosol transmission of COVID-19 in } \\
\text { a situation of inadequate ventilation for several reasons. First, the near- } \\
\text { simultaneous detection of COVID-19 infections of almost all residents healthcare } \\
\text { workers within a ward in which care was provided with surgical masks. Second, } \\
\text { the limitation of the outbreak to this particular ward with a deviating ventilation } \\
\text { system that recirculated unfiltered inside air in combination with the detection of } \\
\text { COVID-19 on the filters of this system. The indoor air was only refreshed with } \\
\text { outside air based on real-time } \mathrm{CO}_{2} \text { concentration measurements. If the } \mathrm{CO}_{2} \\
\text { concentration did not exceed } 1,000 \mathrm{ppm} \text {, the ventilation cabinets recirculated } \\
\text { indoor air back into the ward without filtration. In this situation, low } \mathrm{CO}_{2} \\
\text { production by inactive nursing home patients might have limited the ventilation } \\
\text { with outside air. }\end{array}$ \\
\hline
\end{tabular}




\begin{tabular}{|c|c|c|}
\hline Kimball, Anne et al. & $\begin{array}{l}\text { Asymptomatic and Presymptomatic SARS- } \\
\text { CoV-2 Infections in Residents of a Long- } \\
\text { Term Care Skilled Nursing Facility. } \\
\text { Morbidity and Mortality Weekly Report. }\end{array}$ & $\begin{array}{l}\text { Following identification of a case of COVID-19 in a health care worker, } 76 \text { of } 82 \\
\text { residents of a skilled nursing facility (SNF) were tested for SARS-CoV-2. } 16 \text { days } \\
\text { after the introduction of SARS-CoV-2 into facility A, facility-wide testing identified } \\
\text { a } 30.3 \% \text { prevalence of infection among residents, indicating very rapid spread, } \\
\text { despite early adoption of infection prevention and control measures. } \\
\text { Approximately half of all residents with positive test results did not have any } \\
\text { symptoms at the time of testing, suggesting that transmission from } \\
\text { asymptomatic and presymptomatic residents, who were not recognized as } \\
\text { having SARS-CoV-2 infection and therefore not isolated, might have contributed } \\
\text { to further spread. }\end{array}$ \\
\hline Lynch, Richard M. et al. & $\begin{array}{l}\text { Practical Steps to Improve Air Flow in } \\
\text { Long-Term Care Resident Rooms to } \\
\text { Reduce COVID-19 Infection Risk. Journal of } \\
\text { the American Medical Directors } \\
\text { Association. }\end{array}$ & $\begin{array}{l}\text { The potential for spread of COVID-19 infections in SNFs and other LTC sites poses } \\
\text { new challenges for nursing home administrators to protect patients and staff. It } \\
\text { is anticipated that as acute care hospitals reach capacity, nursing homes may } \\
\text { retain COVID-19 infected residents longer prior to transferring to an acute care } \\
\text { hospital. This article outlines five pragmatic steps that LTC facilities can take to } \\
\text { manage airflow within resident rooms to reduce the potential for spread of } \\
\text { infectious airborne droplets into surrounding areas, including hallways and } \\
\text { adjacent rooms, using strategies adapted from negative-pressure isolation rooms } \\
\text { in acute care facilities. }\end{array}$ \\
\hline Miller, Shelly et al. & $\begin{array}{l}\text { Implementing a Negative Pressure } \\
\text { Isolation Space within a Skilled Nursing } \\
\text { Facility to Control SARS-CoV-2 } \\
\text { Transmission. American Journal of } \\
\text { Infection Control. }\end{array}$ & $\begin{array}{l}\text { The COVID-19 pandemic has an airborne transmission component and requires } \\
\text { isolation, which is difficult to accomplish in SNFs. This study designed, } \\
\text { implemented, and validated an isolation space at an SNF in Lancaster, PA. The } \\
\text { study created an isolation space by modifying an existing HVAC system. It } \\
\text { measured pressure and performed computational fluid dynamics modeling to } \\
\text { test containment and possible transmission given the isolation space is negative } \\
\text { rather than individual rooms. Pressure data shows the isolation space maintained } \\
\text { an average hourly value of (standard deviation) - } 2.3 \mathrm{~Pa}(0.12 \mathrm{~Pa} \text { ) pressure } \\
\text { differential between it and the external hallway connected to the rest of the }\end{array}$ \\
\hline
\end{tabular}




\begin{tabular}{|l|l|l|}
\hline & & $\begin{array}{l}\text { facility. No transmission of SARS-CoV-2 between residents isolated to the space } \\
\text { occurred, nor did the staff or other residents contract SARS-CoV-2. }\end{array}$ \\
\hline
\end{tabular}

Table A-2. Skilled Nursing Facilities-Other Outbreaks

\begin{tabular}{|c|c|c|c|}
\hline Author & Date & Article Title & Summary/Relevant Excerpts \\
\hline $\begin{array}{l}\text { ANSI/ASHRAE/ASHE } \\
\text { Standard 170-2017 }\end{array}$ & 2017 & $\begin{array}{l}\text { Ventilation of Health Care } \\
\text { Facilities - Nursing Facilities }\end{array}$ & $\begin{array}{l}\text { Minimum filter efficiencies for nursing facilities (MERV } 13 \text { ). Minimum outdoor ACH } \\
\text { ( } 2 \text { - patient rooms, } 4 \text { - group spaces). Design temperature } 70^{\circ}-75^{\circ} \mathrm{F} \text {. Isolation space } \\
12 \text { total } \mathrm{ACH},-2.5 \mathrm{~Pa} \text { air pressure relationship to adjacent spaces, no recirculation } \\
\text { air, exhaust directly to outside. }\end{array}$ \\
\hline $\begin{array}{l}\text { Checovich, Mary M. } \\
\text { et al. }\end{array}$ & 2020 & $\begin{array}{l}\text { Evaluation of Viruses Associated } \\
\text { With Acute Respiratory } \\
\text { Infections in Long-Term Care } \\
\text { Facilities Using a Novel Method: } \\
\text { Wisconsin, 2016-2019. Journal } \\
\text { of the American Medical } \\
\text { Directors Association. }\end{array}$ & $\begin{array}{l}\text { Numbers of viruses in each of seven categories (influenza A, influenza B, } \\
\text { coronaviruses, human metapneumovirus, parainfluenza, respiratory syncytial virus, } \\
\text { and rhinovirus/enterovirus) across the three years were compared using c2 } \\
\text { statistical test. Totals of } 160,215 \text {, and } 122 \text { specimens were collected during } 2016- \\
2017,2017-2018 \text {, and } 2018-2019 \text {, respectively. Respiratory pathogen panel } \\
\text { identified viruses in } 54.8 \% \text { of tested specimens. Influenza A (19.2\%), influenza B } \\
(12.6 \%) \text {, respiratory syncytial virus ( } 15.9 \%) \text {, and human metapneumovirus ( } 20.9 \%) \\
\text { accounted for } 69 \% \text { of all detections, whereas coronaviruses (17.2\%), } \\
\text { rhinovirus/enterovirus ( } 10.5 \%) \text {, and parainfluenza (3.8\%) were less common. }\end{array}$ \\
\hline
\end{tabular}




\begin{tabular}{|c|c|c|c|}
\hline Childs, Arielle et al. & 2019 & $\begin{array}{l}\text { The burden of respiratory } \\
\text { infections among older adults in } \\
\text { long-term care: a systematic } \\
\text { review. BMC Geriatrics. }\end{array}$ & $\begin{array}{l}\text { A total of } 1,451 \text { articles were screened for eligibility, } 345 \text { were selected for full-text } \\
\text { review, and } 26 \text { were included. Study population mean ages ranged from } 70.8 \text { to } \\
90.1 \text { years. Three (12\%) studies reported influenza estimates, } 7 \text { ( } 27 \% \text { ) RSV, and } 16 \\
\text { (62\%) pneumonia. Eighteen (69\%) studies reported incidence estimates, } 7 \text { ( } 27 \%) \\
\text { prevalence estimates, and } 1(4 \%) \text { both. Seven ( } 27 \% \text { ) studies reported outbreaks. } \\
\text { Respiratory infection incidence estimates ranged from } 1.1 \% \text { to } 85.2 \% \text { and } \\
\text { prevalence estimates ranging from } 1.4 \% \text { to } 55.8 \% \text {. Influenza incidences ranged from } \\
5.9 \% \text { to } 85.2 \% \text {. RSV incidence proportions ranged from } 1.1 \% \text { to } 13.5 \% \text {. Pneumonia } \\
\text { prevalence proportions ranged from } 1.4 \% \text { to } 55.8 \% \text { while incidence proportions } \\
\text { ranged from } 4.8 \% \text { to } 41.2 \% \text {. }\end{array}$ \\
\hline $\begin{array}{l}\text { Diaz-Decaro, J.D. et } \\
\text { al. }\end{array}$ & 2018 & $\begin{array}{l}\text { Bayesian evidence and } \\
\text { epidemiological implications of } \\
\text { environmental contamination } \\
\text { from acute respiratory infection } \\
\text { in long-term care facilities. } \\
\text { Epidemiology and Infection. }\end{array}$ & $\begin{array}{l}\text { Among nursing home residents with respiratory symptoms, } 19 \% \text { had a detectable } \\
\text { viral pathogen (parainfluenza-3, rhinovirus/enterovirus, RSV, or influenza B). } \\
\text { Environmental contamination was found in } 20 \% \text { of total room surface swabs of } \\
\text { symptomatic residents. Environmental and resident results were all concordant. } \\
\text { Target period prevalence among symptomatic residents ranged from } 5.5 \% \text { to } 13.3 \% \\
\text { depending on target. Bayesian analysis quantifies the probability of environmental } \\
\text { shedding due to parainfluenza-3 as } 92.4 \% \text { ( } 95 \% \mathrm{Cl}: 86.8 \%-95.8 \% \text { ) and due to } \\
\text { rhinovirus/enterovirus as } 65.6 \% \text { ( } 95 \% \mathrm{Cl}: 57.9 \%-72.5 \% \text { ). }\end{array}$ \\
\hline
\end{tabular}




\begin{tabular}{|c|c|c|c|}
\hline Grosskopf et al. & 2014 & $\begin{array}{l}\text { Ventilation and Transport of } \\
\text { Bioaerosols in Health-Care } \\
\text { Environments. ASHRAE Journal. }\end{array}$ & $\begin{array}{l}\text { Air change rate was not found to be effective in reducing respiratory aerosol } \\
\text { concentrations within patient rooms. Increasing air change rates from } 2 \text { to } 5 \mathrm{ACH} \\
\text { reduced concentrations of aerosols }<5 \mu \mathrm{m} \text { only } 30 \% \text { on average. Directional airflow } \\
\text { was found to be effective in containing respiratory aerosol movement from patient } \\
\text { rooms to adjacent corridors. A }-2.5 \text { Pa air pressure relationship between anteroom } \\
\text { and corridor was found to be effective in containing }<5 \mu \mathrm{m} \text { aerosols regardless of } \\
\text { door position or door motion. Within patient rooms, aerosols }<5 \mu \mathrm{m} \text { remained } \\
\text { uniformly distributed at concentrations twice background levels to distances of } 10 \\
\mathrm{ft} \text {. ( } 3 \mathrm{~m} \text { ) from the aerosol injection point (e.g., "patient"). Within corridors, } \\
\text { concentrations of }<5 \mu \mathrm{m} \text { aerosols remained above background levels to distances } \\
\text { exceeding } 80 \mathrm{ft} \text {. }(25 \mathrm{~m} \text { ). Concentrations of aerosols }>5 \mu \mathrm{m} \text { decreased rapidly with } \\
\text { respect to distance, falling below background concentrations } 10 \mathrm{ft} \text {. ( } 3 \mathrm{~m} \text { ) or less } \\
\text { from the aerosol injection point in both patient rooms and corridors. }\end{array}$ \\
\hline $\begin{array}{l}\text { Kovach, Christine R. } \\
\text { et al. }\end{array}$ & 2017 & $\begin{array}{l}\text { Evaluation of an ultraviolet } \\
\text { room disinfection protocol to } \\
\text { decrease nursing home } \\
\text { microbial burden, infection and } \\
\text { hospitalization rates. BMC } \\
\text { Infectious Diseases. }\end{array}$ & $\begin{array}{l}\text { This study was conducted in one } 160 \text {-bed long-term care facility. Following } \\
\text { discharge of each resident, the room was cleaned and then disinfected using a } \\
\text { newly acquired UV light disinfection device. } 36 \text { months of pretest infection and } \\
\text { hospitalization data were compared with } 12 \text { months of posttest data. There were } \\
\text { significant decreases in nursing home-acquired relative to hospital-acquired } \\
\text { infection rates for the total infections ( } p=.004) \text {, urinary tract infection rates ( } p= \\
.014) \text {, respiratory system infection rates }(p=.017) \text {, and for rates of infection of the } \\
\text { skin and soft tissues ( } p=.014) \text {. Hospitalizations for infection decreased significantly, } \\
\text { with a notable decrease in hospitalization for pneumonia ( } p=.006) \text {. Pulsed-xenon } \\
\text { UV disinfection device is superior to manual cleaning on environmental surfaces, as } \\
\text { well as decreasing infection rates. Placing a stronger emphasis on environmental } \\
\text { surface disinfection in LTC facilities may decrease nursing home infections. }\end{array}$ \\
\hline
\end{tabular}




\begin{tabular}{|c|c|c|c|}
\hline $\begin{array}{l}\text { Lansbury, Louise E. } \\
\text { et al. }\end{array}$ & 2017 & $\begin{array}{l}\text { Influenza in long-term care } \\
\text { facilities. Influenza. }\end{array}$ & $\begin{array}{l}\text { LTC facility environments and the vulnerability of their residents provide a setting } \\
\text { conducive to the rapid spread of respiratory pathogens. Infections may be } \\
\text { introduced by staff, visitors, or new or transferred residents, and outbreaks of } \\
\text { influenza in such settings can have devastating consequences for individuals. } \\
\text { Residents sharing a room with an influenza-infected roommate have three times } \\
\text { the risk of acquiring infection than those in single rooms. As the population ages } \\
\text { over the coming decades, increased provision of such facilities seems likely. The } \\
\text { need for robust infection prevention and control practices will therefore remain of } \\
\text { paramount importance if the impact of outbreaks is to be minimized. In this review, } \\
\text { we discuss the nature of the problem of influenza in LTC facilities and approaches to } \\
\text { preventive and control measures, including vaccination of residents and staff, and } \\
\text { the use of antiviral drugs for treatment and prophylaxis, based on currently } \\
\text { available evidence. }\end{array}$ \\
\hline Montoya, Ana et al. & 2011 & $\begin{array}{l}\text { Common infections in nursing } \\
\text { homes: a review of current } \\
\text { issues and challenges. Aging } \\
\text { Health. }\end{array}$ & $\begin{array}{l}\text { More than } 1.5 \text { million people live in } 16,000 \text { nursing homes in the United States, } \\
\text { according to the } 2004 \text { National Nursing Home Survey. More than } 88 \% \text { of these } \\
\text { people are } 65 \text { years of age and older, and } 45 \% \text { are age } 85 \text { years and older. It is } \\
\text { estimated that the number of people who will require nursing home care in the } \\
\text { United States will reach } 5.3 \text { million by } 2030 \text {. The acuity of illness in this population } \\
\text { has increased substantially in the last decade, as has the risk of acquiring new } \\
\text { infections. Although recent estimates are lacking, approximately } 2 \text { million infections } \\
\text { occur in U.S. nursing homes each year. In addition, a point prevalence survey } \\
\text { revealed that the prevalence of nursing home-associated infections on the day of } \\
\text { the survey was } 5.2 \% \text { in Veterans Administration Community Living Center facilities } \\
\text { in the United States. Internationally, a three-year study in the Netherlands reported } \\
\text { a prevalence of healthcare-associated infections of } 6.7 \% \text { in } 2007,7.6 \% \text { in } 2008 \text {, and } \\
7.6 \% \text { in } 2009 \text {, ranging from } 0 \% \text { to } 32.4 \% \text { between nursing homes. }\end{array}$ \\
\hline
\end{tabular}




\begin{tabular}{|l|l|l|l|}
\hline & & & $\begin{array}{l}\text { Nursing homes provide an ideal environment for acquisition and spread of } \\
\text { infection: susceptible residents who share sources of air, food, water, and health } \\
\text { care in a crowded institutional setting. Moreover, visitors, staff, and residents } \\
\text { constantly come and go, bringing in pathogens from both the hospital and the } \\
\text { Strausbaugh, Larry J. } 2003 \\
\text { community. Outbreaks of respiratory and gastrointestinal infection predominate in } \\
\text { this setting. Outbreaks of respiratory and gastrointestinal infection predominate in } \\
\text { this setting. Depending on the infectious agent, they may spread via large } \\
\text { Unappiratory droplets, direct or indirect contact, or airborne droplet nuclei. Disease } \\
\text { Elderly Persons. Clinical } \\
\text { Infectious Diseases. }\end{array}$ \\
\hline
\end{tabular}


Table A-3. CoVID-19-General Information

\begin{tabular}{|c|c|c|c|}
\hline Author & Date & Article Title & Summary/Relevant Excerpts \\
\hline $\begin{array}{l}\text { Alvarez-Ramirez, Jose } \\
\text { Sr. et al. }\end{array}$ & 2020 & $\begin{array}{l}\text { Role of meteorological } \\
\text { temperature and relative } \\
\text { humidity in the January- } \\
\text { February } 2020 \text { propagation of } \\
\text { 2019-nCoV in Wuhan, China. } \\
\text { (Preprint). }\end{array}$ & $\begin{array}{l}\text { The long-term trend of temperature and relative humidity were obtained with a 14- } \\
\text { day adjacent-averaging filter, and lagged correlations of the number of daily confirmed } \\
\text { cases were explored. The analysis showed negative correlations between } \\
\text { temperatures with the number of daily confirmed cases. Maximum correlations were } \\
\text { found for six-day lagged temperatures, which is likely reflecting the incubation period } \\
\text { of the virus. It was postulated that the indoor crowding effect is responsible of the } \\
\text { high incidence of } 2019-n C o V \text { cases, where low absolute humidity and close human } \\
\text { contact facilitate the transport of aerosol droplets. }\end{array}$ \\
\hline $\begin{array}{l}\text { Anderson, Elizabeth } \\
\text { L. } \\
\text { et al. }\end{array}$ & 2020 & $\begin{array}{l}\text { Consideration of the Aerosol } \\
\text { Transmission for COVID-19 and } \\
\text { Public Health. Risk Analysis. }\end{array}$ & $\begin{array}{l}\text { This article analyzes the available evidence to address airborne, aerosol transmission } \\
\text { of SARS-CoV-2. We review and present three lines of evidence: case reports of } \\
\text { transmission for asymptomatic individuals in association with studies that show that } \\
\text { normal breathing and talking produce predominantly small droplets of the size that } \\
\text { are subject to aerosol transport; limited empirical data that have recorded aerosolized } \\
\text { SARS-CoV-2 particles that remain suspended in the air for hours and are subject to } \\
\text { transport over distances including outside of rooms and intrabuilding, and the broader } \\
\text { literature that further supports the importance of aerosol transmission of infectious } \\
\text { diseases. The weight of the available evidence warrants immediate attention to } \\
\text { address the significance of aerosols and implications for public health protection. }\end{array}$ \\
\hline $\begin{array}{l}\text { Araujo, Miguel B. et } \\
\text { al. }\end{array}$ & 2020 & $\begin{array}{l}\text { Spread of SARS-CoV-2 } \\
\text { Coronavirus likely to be } \\
\text { constrained by climate. } \\
\text { (Preprint). }\end{array}$ & $\begin{array}{l}\text { The emergence of asynchronous seasonal global outbreaks much like other respiratory } \\
\text { diseases is probable. People in temperate warm and cold climates are more } \\
\text { vulnerable. Those in arid climates follow next in vulnerability, while the disease will } \\
\text { likely marginally affect the tropics. Our projections minimize uncertainties related with } \\
\text { spread of SARS CoV-2, providing critical information for anticipating the adequate } \\
\text { social, economic, and political responses. }\end{array}$ \\
\hline
\end{tabular}




\begin{tabular}{|c|c|c|c|}
\hline ASHRAE & 2020 & $\begin{array}{l}\text { ASHRAE Position Document on } \\
\text { Infectious Aerosols. }\end{array}$ & $\begin{array}{l}\text { ASHRAE's position is that facilities of all types should follow, as a minimum, the latest } \\
\text { published standards and guidelines and good engineering practice. ANSI/ASHRAE } \\
\text { Standards } 62.1 \text { and } 62.2 \text { include requirements for outdoor air ventilation in most } \\
\text { residential and nonresidential spaces, and ANSI/ASHRAE/ASHE Standard } 170 \text { covers } \\
\text { both outdoor and total air ventilation in healthcare facilities. Based on risk } \\
\text { assessments or owner project requirements, designers of new and existing facilities } \\
\text { could go beyond the minimum requirements of these standards, using techniques } \\
\text { covered in various ASHRAE publications, including the ASHRAE Handbook volumes, } \\
\text { Research Project final reports, papers and articles, and design guides, to be even } \\
\text { better prepared to control the dissemination of infectious aerosols. }\end{array}$ \\
\hline Azimi, Parham et al. & 2020 & $\begin{array}{l}\text { Mechanistic Transmission } \\
\text { Modeling of COVID-19 on the } \\
\text { Diamond Princess Cruise Ship } \\
\text { Demonstrates the Importance } \\
\text { of Aerosol Transmission. } \\
\text { Proceedings of the National } \\
\text { Academy of Sciences of the } \\
\text { United States of America. }\end{array}$ & $\begin{array}{l}\text { The current prevailing position is that COVID-19 is transmitted primarily through large } \\
\text { respiratory droplets within close proximity (i.e., } 1-2 \mathrm{~m} \text { ) of infected individuals. } \\
\text { However, quantitative information on the relative importance of specific transmission } \\
\text { pathways of SARS-CoV-2 (i.e., droplets, aerosols, and fomites across short- and long- } \\
\text { range distances) remains limited. Mean estimates of the contributions of short-range, } \\
\text { long-range, and fomite transmission modes to infected cases aboard the ship across } \\
\text { the entire simulation time period were } 35 \%, 35 \% \text {, and } 30 \% \text {, respectively. Mean } \\
\text { estimates of the contributions of large respiratory droplets and small respiratory } \\
\text { aerosols were } 41 \% \text { and } 59 \% \text {. Short-range transmission was the dominant mode after } \\
\text { passenger quarantine began, albeit due primarily to aerosol transmission, not } \\
\text { droplets. }\end{array}$ \\
\hline $\begin{array}{l}\text { Bannister-Tyrrell, } \\
\text { Melanie et al. }\end{array}$ & 2020 & $\begin{array}{l}\text { Preliminary evidence that higher } \\
\text { temperatures are associated } \\
\text { with lower incidence of COVID- } \\
19 \text {, for cases reported globally } \\
\text { up to 29th February } 2020 . \\
\text { (Preprint). }\end{array}$ & $\begin{array}{l}\text { Using global line-list data on COVID-19 cases reported until February } 29,2020 \text {, and } \\
\text { global gridded temperature data, and after adjusting for surveillance capacity and time } \\
\text { since first imported case, higher average temperature was strongly associated with } \\
\text { lower COVID-19 incidence for temperatures of } 1^{\circ} \mathrm{C} \text { and higher. However, temperature } \\
\text { explained a relatively modest amount of the total variation in COVID-19 incidence. } \\
\text { These preliminary findings support stringent containment efforts in Europe and } \\
\text { elsewhere. }\end{array}$ \\
\hline
\end{tabular}




\begin{tabular}{|c|c|c|c|}
\hline $\begin{array}{l}\text { Biqing, Chen } \\
\text { et al. }\end{array}$ & 2020 & $\begin{array}{l}\text { Roles of meteorological } \\
\text { conditions in COVID-19 } \\
\text { transmission on a worldwide } \\
\text { scale. (Preprint). }\end{array}$ & $\begin{array}{l}\text { This paper examines the relationships of meteorological variables with the severity of } \\
\text { the outbreak on a worldwide scale. The confirmed case counts, which indicate the } \\
\text { severity of COVID-19 spread, and four meteorological variables-air temperature, } \\
\text { relative humidity, wind speed, and visibility-were collected daily between January } 20 \\
\text { and March } 11 \text { ( } 52 \text { days) for } 430 \text { cities and districts all over China, } 21 \text { cities/provinces in } \\
\text { Italy, } 21 \text { cities/provinces in Japan, and } 51 \text { other countries around the world. Four } \\
\text { different time delays of weather (on the day, } 3 \text { days ago, } 7 \text { days ago, and } 14 \text { days ago) } \\
\text { as to the epidemic situation were taken for modeling and we finally chose the weather } \\
\text { two weeks ago to model against the daily epidemic situation as it is best correlated } \\
\text { with the outbreak. Taking Chinese cities as a discovery data set, it was suggested that } \\
\text { temperature, wind speed, and relative humidity combined together could best predict } \\
\text { the epidemic situation. }\end{array}$ \\
\hline Bourouiba, Lydia & 2020 & $\begin{array}{l}\text { Turbulent Gas Clouds and } \\
\text { Respiratory Pathogen Emissions } \\
\text { Potential Implications for } \\
\text { Reducing Transmission of } \\
\text { COVID-19. Journal of the } \\
\text { American Medical Association. }\end{array}$ & $\begin{array}{l}\text { Given various combinations of an individual patient's physiology and environmental } \\
\text { conditions such as humidity and temperature, the gas cloud and its payload of } \\
\text { pathogen-bearing droplets of all sizes can travel } 23 \text { to } 27 \text { feet ( } 7-8 \mathrm{~m} \text { ). Throughout the } \\
\text { trajectory, droplets of all sizes settle out or evaporate at rates that depend not only on } \\
\text { their size, but also on the degree of turbulence and speed of the gas cloud, coupled } \\
\text { with the properties of the ambient environment (temperature, humidity, and airflow). }\end{array}$ \\
\hline $\begin{array}{l}\text { Buonanno, Manuela } \\
\text { et al. }\end{array}$ & 2020 & $\begin{array}{l}\text { Far-UVC light efficiently and } \\
\text { safely inactivates airborne } \\
\text { human coronaviruses. Scientific } \\
\text { Reports. }\end{array}$ & $\begin{array}{l}\text { Far-ultraviolet C (UVC) light ( } 207-222 \mathrm{~nm} \text { ) efficiently kills pathogens without harm to } \\
\text { exposed human cells or tissues. We previously demonstrated that UVC kills pathogens } \\
\text { without harm at } 222 \text {-nm wavelengths. We extend the far-UVC studies to explore } \\
\text { efficacy against human coronaviruses from subgroups alpha (HCoV-229E) and beta } \\
\text { (HCoV-OC43). We found that low doses of, respectively, } 1.7 \text { and } 1.2 \mathrm{~mJ} / \mathrm{cm}^{2} \\
\text { inactivated } 99.9 \% \text { of aerosolized alpha coronavirus } 229 \mathrm{E} \text { and beta coronavirus OC43. } \\
\text { Based on these results for the beta HCoV-OC43 coronavirus, continuous far-UVC } \\
\text { exposure in public locations at the currently recommended exposure limit (3 } \\
\mathrm{mJ} / \mathrm{cm}^{2} / \text { hour) would result in } 99.9 \% \text { viral inactivation in approximately } 25 \text { minutes. } \\
\text { Increasing the far-UVC intensity by, say, a factor of } 2 \text { would halve these disinfection } \\
\text { times, while still maintaining safety. As coronaviruses have similar genomic size, a key } \\
\text { determinant of radiation sensitivity, it is realistic to expect that far-UVC light will show }\end{array}$ \\
\hline
\end{tabular}




\begin{tabular}{|c|c|c|c|}
\hline & & & $\begin{array}{l}\text { comparable inactivation efficiency against other human coronaviruses, including SARS- } \\
\text { CoV-2. }\end{array}$ \\
\hline CDC & 2019 & $\begin{array}{l}\text { Novel Coronavirus RT-PCR } \\
\text { Identification Protocols. }\end{array}$ & $\begin{array}{l}\text { The CDC 2019-Novel Coronavirus (2019-nCoV) Real-Time RT-PCR Diagnostic Panel is a } \\
\text { real-time RT-PCR test intended for the qualitative detection of nucleic acid from the } \\
2019-n C o V \text { in upper and lower respiratory specimens (such as nasopharyngeal or } \\
\text { oropharyngeal swabs, sputum, lower respiratory tract aspirates, bronchoalveolar } \\
\text { lavage, and nasopharyngeal wash/aspirate or nasal aspirate) collected from individuals } \\
\text { who meet 2019-nCoV clinical and/or epidemiological criteria. }\end{array}$ \\
\hline Chia P.Y. et al. & 2020 & $\begin{array}{l}\text { Detection of Air and Surface } \\
\text { Contamination by Severe Acute } \\
\text { Respiratory Syndrome } \\
\text { Coronavirus } 2 \text { (SARS-CoV-2) in } \\
\text { Hospital Rooms of Infected } \\
\text { Patients. Nature } \\
\text { Communications. }\end{array}$ & 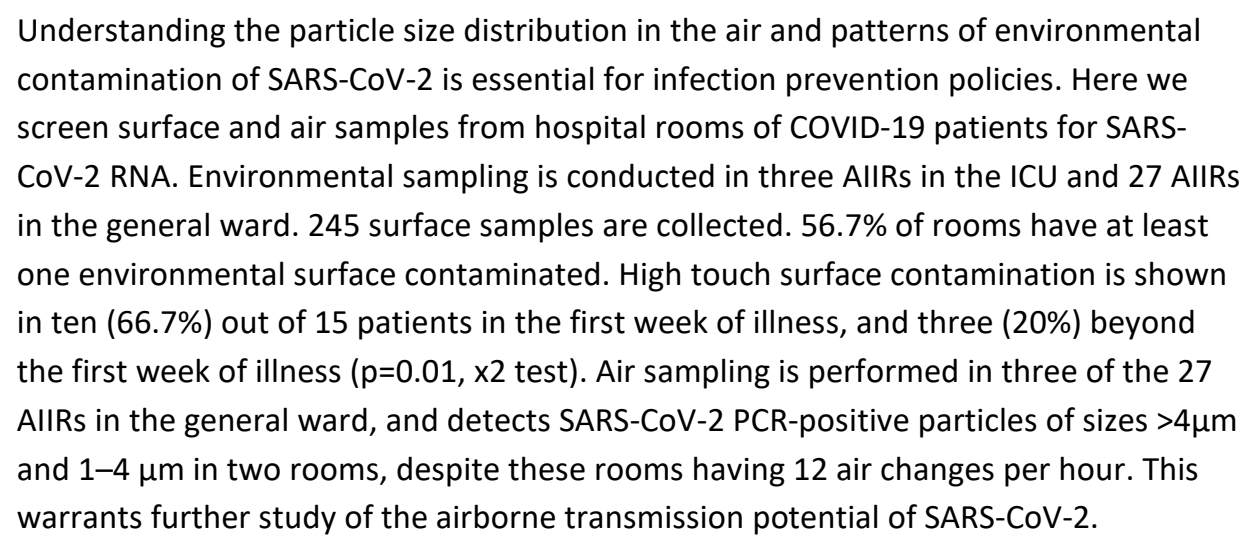 \\
\hline Chin, A. et al. & 2020 & $\begin{array}{l}\text { Stability of SARS- CoV-2 in } \\
\text { different environmental } \\
\text { conditions. Lancet Microbe. }\end{array}$ & $\begin{array}{l}\text { SARS-CoV-2 can be highly stable in a favorable environment, but it is also susceptible } \\
\text { to standard disinfection methods. }\end{array}$ \\
\hline
\end{tabular}




\begin{tabular}{|c|c|c|c|}
\hline Corman, V. M. et al. & 2020 & $\begin{array}{l}\text { Detection of } 2019 \text { novel } \\
\text { coronavirus (2019-nCoV) by } \\
\text { real-time RT-PCR. } \\
\text { Eurosurveillance. }\end{array}$ & $\begin{array}{l}\text { The workflow reliably detects } 2019-\mathrm{nCoV} \text {, and further discriminates } 2019-\mathrm{nCoV} \text { from } \\
\text { SARS-CoV. Through coordination between academic and public laboratories, we } \\
\text { confirmed assay exclusivity based on } 297 \text { original clinical specimens containing a full } \\
\text { spectrum of human respiratory viruses. Control material is made available through } \\
\text { European Virus Archive - Global, a European Union infrastructure project. }\end{array}$ \\
\hline $\begin{array}{l}\text { da Silva, Manuel } \\
\text { Carlos Gameiro }\end{array}$ & 2020 & $\begin{array}{l}\text { An analysis of the transmission } \\
\text { modes of COVID-19 in light of } \\
\text { the concepts of Indoor Air } \\
\text { Quality. (Preprint). }\end{array}$ & Typical trajectories of particles in the air, depending on their size. \\
\hline Dai, Hui et al. & 2020 & $\begin{array}{l}\text { Association of the infection } \\
\text { probability of COVID-19 with } \\
\text { ventilation rates in confined } \\
\text { spaces. Building Simulation. }\end{array}$ & $\begin{array}{l}\text { A growing number of cases have proved the possibility of airborne transmission of } \\
\text { COVID-19. Ensuring an adequate ventilation rate is essential to reduce the risk of } \\
\text { infection in confined spaces. In this study, we estimated the association between the } \\
\text { infection probability and ventilation rates with the Wells-Riley equation, where the } \\
\text { quantum generation rate (q) by a COVID- } 19 \text { infector was obtained using a reproductive } \\
\text { number-based fitting approach. The estimated q value of COVID- } 19 \text { is } 14-48 \mathrm{~h}-1 \text {. To } \\
\text { ensure an infection probability of less than } 1 \% \text {, a ventilation rate larger than common } \\
\text { values (100-350 } \mathrm{m}^{3} / \mathrm{h} \text { per infector and } 1,200-4,000 \mathrm{~m}^{3} / \mathrm{h} \text { per infector for } 0.25 \mathrm{~h} \text { and } 3 \\
\mathrm{~h} \text { of exposure, respectively) is required. }\end{array}$ \\
\hline $\begin{array}{l}\text { Ding, Zhen } \\
\text { et al. }\end{array}$ & 2020 & $\begin{array}{l}\text { Toilets dominate environmental } \\
\text { detection of SARS-CoV-2 virus in } \\
\text { a hospital. Science of the Total } \\
\text { Environment. }\end{array}$ & $\begin{array}{l}\text { The } 107 \text { surface samples comprised } 37 \text { from toilets, } 34 \text { from other surfaces isolation } \\
\text { rooms (ventilated at } 3030-60 \mathrm{~L} / \mathrm{s} \mathrm{s} \text { ), and } 36 \text { from other surfaces outside isolation } \\
\text { rooms in the hospital. Four of these samples were positive, namely two ward door } \\
\text { handles, one bathroom toilet seat cover and one bathroom door handle; and three } \\
\text { were weakly positive, namely one bathroom toilet seat, one bathroom washbasin tap } \\
\text { lever, and one bathroom ceiling-exhaust louvre. One of the } 46 \text { air samples was weakly } \\
\text { positive, and this was a corridor air sample. The two exhaled condensate samples and } \\
\text { the two expired air samples were negative. }\end{array}$ \\
\hline
\end{tabular}




\begin{tabular}{|c|c|c|c|}
\hline $\begin{array}{l}\text { European Centre for } \\
\text { Disease Prevention } \\
\text { and Control (ECDPC) }\end{array}$ & 2020 & $\begin{array}{l}\text { Interim guidance for } \\
\text { environmental cleaning in non- } \\
\text { healthcare facilities exposed to } \\
\text { SARS-CoV-2. }\end{array}$ & $\begin{array}{l}\text { The use of } 0.1 \% \text { sodium hypochlorite (dilution } 1: 50 \text { if household bleach at an initial } \\
\text { concentration of } 5 \% \text { is used) after cleaning with a neutral detergent is suggested for } \\
\text { decontamination purposes, although no data on the effectiveness against SARS-CoV- } 2 \\
\text { are available. For surfaces that could be damaged by sodium hypochlorite, } 70 \% \\
\text { concentration of ethanol is needed for decontamination after cleaning with a neutral } \\
\text { detergent. }\end{array}$ \\
\hline $\begin{array}{l}\text { Federation of } \\
\text { European Heating, } \\
\text { Ventilation and Air } \\
\text { Conditioning } \\
\text { Associations (REHVA) }\end{array}$ & 2020 & $\begin{array}{l}\text { Preventing COVID-19 Spreading } \\
\text { in Buildings. }\end{array}$ & $\begin{array}{l}\text { Increase air supply and exhaust ventilation. Humidification has no practical effect. } \\
\text { Room air cleaners can be useful. Safe use of heat-recovery sections. No use of } \\
\text { recirculation. UV and filters. }\end{array}$ \\
\hline $\begin{array}{l}\text { Ficetola, Francesco et } \\
\text { al. }\end{array}$ & 2020 & $\begin{array}{l}\text { Climate affects global patterns } \\
\text { of COVID-19 early outbreak } \\
\text { dynamics. (Preprint) }\end{array}$ & $\begin{array}{l}\text { Growth rates peaked in temperate regions of the Northern Hemisphere with mean } \\
\text { temperature of approximately } 5 \text { degrees, and humidity of approximately } 0.6-1 \mathrm{kPa} \\
\text { during the outbreak month, while they decreased in warmer and colder regions. The } \\
\text { strong relationship between local climate and COVID-19 growth rates suggests the } \\
\text { possibility of seasonal variation in the spatial pattern of outbreaks, with temperate } \\
\text { regions of the Southern Hemisphere becoming at particular risk of severe outbreaks } \\
\text { during the next months. }\end{array}$ \\
\hline Fottrell, Quentin & 2020 & $\begin{array}{l}\text { Coronavirus droplets caused by } \\
\text { talking remain in the air for } 8- \\
14 \text { minutes. } C N B C \text {. }\end{array}$ & $\begin{array}{l}\text { Speech droplets generated by asymptomatic carriers of SARS-CoV- } 2 \text { are increasingly } \\
\text { considered to be a likely mode of disease transmission. Highly sensitive laser light } \\
\text { scattering observations have revealed that loud speech can emit thousands of oral } \\
\text { fluid droplets per second. In a closed, stagnant-air environment, they disappear from } \\
\text { view after } 8 \text { minutes to } 14 \text { minutes, which corresponds to droplet nuclei of } 4 \mu \mathrm{m} \\
\text { diameter, or } 12 \mu \mathrm{m} \text { to } 21 \mu \mathrm{m} \text { droplets prior to dehydration. The coronavirus is } 0.125 \\
\mu \mathrm{m} \text {. }\end{array}$ \\
\hline
\end{tabular}




\begin{tabular}{|c|c|c|c|}
\hline $\begin{array}{l}\text { Ghaffarzadegan } \\
\text { Navid et al. }\end{array}$ & 2020 & $\begin{array}{l}\text { Simulation-based Estimation of } \\
\text { the Spread of COVID-19 in Iran. } \\
\text { (Preprint). }\end{array}$ & $\begin{array}{l}\text { The trajectory of the epidemic until the end of June could take various paths } \\
\text { depending on the impact of seasonality and policies targeting social distancing. In the } \\
\text { most optimistic scenario for seasonal effects, depending on policy measures, } 1.6 \\
\text { million Iranians }(90 \% \mathrm{Cl}: 0.9 \mathrm{M}-2.6 \mathrm{M}) \text { are likely to get infected, and death toll will } \\
\text { reach about } 58,000 \text { cases }(90 \% \mathrm{Cl}: 32 \mathrm{~K}-97 \mathrm{~K}) \text {, while in the more pessimistic scenarios, } \\
\text { death toll may exceed } 103,000 \text { cases ( } 90 \% \mathrm{Cl}: 56 \mathrm{~K}-172 \mathrm{~K}) \text {. Implication: Our results } \\
\text { suggest that the number of cases and deaths may be over an order of magnitude } \\
\text { larger than official statistics in Iran. Absent extended testing capacity, other countries } \\
\text { may face a significant under-count of existing cases and thus be caught off guard } \\
\text { about the actual toll of the epidemic. }\end{array}$ \\
\hline Gorbunov, B. & 2020 & $\begin{array}{l}\text { Aerosol particles laden with } \\
\text { COVID-19 travel over } 30 \mathrm{~m} \\
\text { distance. (Preprint). }\end{array}$ & $\begin{array}{l}\text { The results obtained demonstrate that aerosol particles generated by coughing and } \\
\text { sneezing can travel over } 30 \mathrm{~m} \text {. Modelling of the evolution of aerosol clouds generated } \\
\text { by coughing and sneezing enables us to evaluate the deposition dose of aerosol } \\
\text { particles in healthy individuals. For example, a person in a public place (e.g., } \\
\text { supermarket or car park) can accumulate in the respiratory system up to } 200 \text { virus } \\
\text { copies in } 2 \text { minutes' time by breathing in virus-laden aerosols. Wearing a face mask } \\
\text { considerably reduces the deposited load down to } 2 \text { virus copies per } 2 \text { minute. }\end{array}$ \\
\hline Guan, L. et al. & 2020 & $\begin{array}{l}\text { More awareness is needed for } \\
\text { severe acute respiratory } \\
\text { syndrome coronavirus } 2019 \\
\text { transmission through exhaled } \\
\text { air during non-invasive } \\
\text { respiratory support: experience } \\
\text { from China. European } \\
\text { Respiratory Journal. }\end{array}$ & $\begin{array}{l}\text { Human-to-human spread of the virus via respiratory droplets is currently considered } \\
\text { to be the main route of transmission. However, exhaled air dispersion during non- } \\
\text { invasive respiratory support may increase the risk of coronavirus transmission, and } \\
\text { requires more attention from medical personnel and patients. }\end{array}$ \\
\hline
\end{tabular}




\begin{tabular}{|c|c|c|c|}
\hline Guo, Z. et al. & 2020 & $\begin{array}{l}\text { Aerosol and Surface Distribution } \\
\text { of Severe Acute Respiratory } \\
\text { Syndrome Coronavirus } 2 \text { in } \\
\text { Hospital Wards, Wuhan, China, } \\
\text { 2020. Emerging Infectious } \\
\text { Diseases. }\end{array}$ & $\begin{array}{l}\text { This study led to three conclusions. First, SARS-CoV-2 was widely distributed in the air } \\
\text { and on object surfaces in both the ICU and general ward, implying a potentially high } \\
\text { infection risk for medical staff and other close contacts. Second, the environmental } \\
\text { contamination was greater in the ICU than in the general ward; thus, stricter } \\
\text { protective measures should be taken by medical staff working in the ICU. Third, the } \\
\text { SARS-CoV-2 aerosol distribution characteristics in the ICU indicate that the } \\
\text { transmission distance of SARS-CoV-2 might be } 4 \mathrm{~m} \text {. }\end{array}$ \\
\hline $\mathrm{He}$, X. et al. & 2020 & $\begin{array}{l}\text { Temporal dynamics in viral } \\
\text { shedding and transmissibility of } \\
\text { COVID-19. Natural Medicine. }\end{array}$ & $\begin{array}{l}\text { We report temporal patterns of viral shedding in } 94 \text { patients with laboratory- } \\
\text { confirmed COVID-19 and modeled COVID-19 infectiousness profiles from a separate } \\
\text { sample of } 77 \text { infector-infectee transmission pairs. We observed the highest viral load } \\
\text { in throat swabs at the time of symptom onset, and inferred that infectiousness peaked } \\
\text { on or before symptom onset. We estimated that } 44 \% \text { ( } 95 \% \text { confidence interval, } 30 \%- \\
57 \% \text { ) of secondary cases were infected during the index cases' presymptomatic stage, } \\
\text { in settings with substantial household clustering, active case finding and quarantine } \\
\text { outside the home. Disease control measures should be adjusted to account for } \\
\text { probable substantial presymptomatic transmission. }\end{array}$ \\
\hline $\begin{array}{l}\text { Horve, Patrick F. et } \\
\text { al. }\end{array}$ & 2020 & $\begin{array}{l}\text { Identification of SARS-CoV-2 } \\
\text { RNA in Healthcare Heating, } \\
\text { Ventilation, and Air Conditioning } \\
\text { Units. (Preprint). }\end{array}$ & $\begin{array}{l}\text { Available information on SARS-CoV- } 2 \text { transmission by small particle aerosols continues } \\
\text { to evolve rapidly. To assess the potential role of HVAC systems in airborne viral } \\
\text { transmission, this study sought to determine the viral presence, if any, on air handling } \\
\text { units in a healthcare setting where COVID-19 patients were being treated. The } \\
\text { presence of SARS-CoV- } 2 \text { RNA was detected in approximately } 25 \% \text { of samples taken } \\
\text { from nine different locations in multiple air handlers. }\end{array}$ \\
\hline Houser, Kevin W. & 2020 & $\begin{array}{l}\text { Ten Facts about UV Radiation } \\
\text { and COVID-19. The Journal of } \\
\text { the Illuminating Engineering } \\
\text { Society. }\end{array}$ & $\begin{array}{l}\text { The COVID-19 pandemic has generated interest in the potential of UV radiation to } \\
\text { disinfect air and surfaces. In response, the IES Photobiology Committee published a } \\
\text { freely available report about germicidal ultraviolet radiation. As an even-handed } \\
\text { treatment of UV radiation's potential and limitations, the report is a welcomed } \\
\text { counterpoint to information appearing in social media feeds, the popular press, and in } \\
\text { shady sales literature. Included are ten facts about UV radiation and COVID-19. }\end{array}$ \\
\hline
\end{tabular}




\begin{tabular}{|c|c|c|c|}
\hline $\begin{array}{l}\text { Illuminating } \\
\text { Engineering Society } \\
\text { (IES) }\end{array}$ & 2020 & Germicidal Ultraviolet (GUV). & $\begin{array}{l}\text { Commonly used GUV lamps generate predominantly } 254-n m \text { UV radiant energy, which } \\
\text { is close to the peak germicidal wavelengths of } 265 \text { to } 270 \mathrm{~nm} \text {-both in the UV-C range, } \\
\text { compared to the longer-wavelength ultraviolet (UV-A and UV-B) in sunlight. GUV } \\
\text { radiant energy damages nucleic acids (DNA and RNA) by causing mutations that } \\
\text { prevent replication, thus leading to the death of virtually all bacteria and inactivation } \\
\text { of all viruses - both DNA and RNA types. Bacteria and viruses vary somewhat in UV } \\
\text { susceptibility, with environmental organisms, fungal spores, and mycobacteria being } \\
\text { relatively harder to kill than more rapidly replicating and non-environmental microbes } \\
\text { and most bacteria. But even fungi are effectively killed with high-dose UV, which is } \\
\text { used, for example, to treat fungal contamination of air conditioning systems. GUV can } \\
\text { be most effectively used to disinfect air in the upper room where ceiling height } \\
\text { permits, but can also be used in ventilation ducts and room air cleaners, as noted. } \\
\text { Upper-room GUV is considered the most effective application for room air } \\
\text { disinfection. }\end{array}$ \\
\hline $\begin{array}{l}\text { Illinois Institute of } \\
\text { Technology (IIT) }\end{array}$ & 2020 & Filtration of Infectious Aerosols. & $\begin{array}{l}\text { MERV } 5,7 \text {, and } 11 \text { filters are expected to provide infection risk reductions of } 25 \% \text {, } \\
50 \% \text {, and } 60 \% \text {. MERV } 13 \text { + filters are expected to provide infection risk reductions } \\
>65 \% \text {. }\end{array}$ \\
\hline Jameel, Yusuf & 2020 & $\begin{array}{l}\text { Will coronavirus pandemic } \\
\text { diminish by summer? (Preprint). }\end{array}$ & $\begin{array}{l}\text { Even though currently available data is skewed by minimal testing per capita in many } \\
\text { tropical countries, it is possible that weather plays a role in the spread of } 2019-\mathrm{nCoV} \\
\text { which warrants an investigation. In the last } 10 \text { days, thousands of new cases have } \\
\text { been documented in regions with } \mathrm{T}>18^{\circ} \mathrm{C} \text { suggesting that the role of warmer } \\
\text { temperature in slowing the spread of the } 2019-\mathrm{nCoV} \text {, as suggested earlier might only } \\
\text { be observed, if at all, at much higher temperatures. Unlike temperature, however, the } \\
\text { range of average humidity (AH) across which most of the cases have been documented } \\
\text { has consistently been between } 3 \text { and } 9 \mathrm{~g} / \mathrm{m}^{3} \text {. Current data, although limited, suggests } \\
\text { that it is extremely unlikely that the spread of } 2019 \text {-nCoV would slow down in the } \\
\text { United States or Europe due to environmental factors, because a large number of } \\
\text { cases have already been reported in the range of AH and T experienced by these } \\
\text { regions for most part of the year. }\end{array}$ \\
\hline
\end{tabular}




\begin{tabular}{|c|c|c|c|}
\hline $\begin{array}{l}\text { Jayaweera, Mahesh } \\
\text { et al. }\end{array}$ & 2020 & $\begin{array}{l}\text { Transmission of COVID-19 virus } \\
\text { by droplets and aerosols. } \\
\text { Environmental Research. }\end{array}$ & $\begin{array}{l}\text { The complete control of virus-laden droplet and aerosol transmission is poorly } \\
\text { understood. This review paper intends to outline the literature concerning the } \\
\text { transmission of virus-laden droplets and aerosols in different environmental settings } \\
\text { and demonstrates the behavior of droplets and aerosols resulted from a coughjet of } \\
\text { an infected person in various confined spaces. Airborne transmission plays a profound } \\
\text { role in contracting susceptible hosts. The infection propensities in confined spaces } \\
\text { (airplane, passenger car, and healthcare center) by the transmission of droplets and } \\
\text { aerosols under varying ventilation conditions were discussed. Interestingly, the } \\
\text { nosocomial transmission by airborne SARS-CoV-2 virus-laden aerosols in healthcare } \\
\text { facilities may be plausible. Hence, clearly defined, science-based administrative, } \\
\text { clinical, and physical measures are of paramount importance to eradicate the COVID- } \\
19 \text { pandemic from the world. }\end{array}$ \\
\hline Kai, Yang et al. & 2020 & $\begin{array}{l}\text { Analysis of epidemiological } \\
\text { characteristics of coronavirus } \\
2019 \text { infection and preventive } \\
\text { measures in Shenzhen China: a } \\
\text { heavy population city. } \\
\text { (Preprint). }\end{array}$ & $\begin{array}{l}\text { Shenzhen ranked the top cities outside Wuhan with a reported } 416 \text { confirmed cases by } \\
\text { February } 20,2020 \text {. Here, we analyzed the epidemiological characteristics of COVID- } 19 \\
\text { in Shenzhen and potential links to the preventive strategies for the whole city and } \\
\text { inside hospitals. Based on the daily new cases, the epidemic of COVID-19 in Shenzhen } \\
\text { can be classified into three phases: the slow increase phase from January } 19 \text { to } \\
\text { January } 28 \text {, the rapid increase and plateau phase from January } 29 \text { to February } 5 \text {, and } \\
\text { the decline phase since February } 6 \text {. In the three phases, the number of patients from } \\
\text { Hubei decreased, and the number of familial clustering cases increased. }\end{array}$ \\
\hline $\begin{array}{l}\text { Kissler, Stephen M. } \\
\text { et al. }\end{array}$ & 2020 & $\begin{array}{l}\text { Projecting the transmission } \\
\text { dynamics of SARS-CoV-2 } \\
\text { through the post-pandemic } \\
\text { period. Science. }\end{array}$ & $\begin{array}{l}\text { These dynamics will depend on seasonality, the duration of immunity, and the } \\
\text { strength of cross-immunity to/from the other human coronaviruses. Using data from } \\
\text { the United States, we measured how these factors affect transmission of human } \\
\text { betacoronaviruses HCoV-OC43 and HCoV-HKU1. We then built a mathematical model } \\
\text { to simulate transmission of SARS-CoV-2 through the year 2025. We project that } \\
\text { recurrent wintertime outbreaks of SARS-CoV-2 will probably occur after an initial } \\
\text { pandemic wave. We summarize the full range of plausible transmission scenarios and } \\
\text { identify key data still needed to distinguish between them, most importantly } \\
\text { longitudinal serological studies to determine the duration of immunity to SARS-CoV-2. }\end{array}$ \\
\hline
\end{tabular}




\begin{tabular}{|c|c|c|c|}
\hline $\begin{array}{l}\text { Klompas, Michael et } \\
\text { al. }\end{array}$ & 2020 & $\begin{array}{l}\text { Airborne Transmission of SARS- } \\
\text { CoV-2. Journal of the American } \\
\text { Medical Association. }\end{array}$ & $\begin{array}{l}\text { The reproduction number for COVID-19 before measures were taken to mitigate its } \\
\text { spread was estimated to be about } 2.5 \text {, meaning that each person with COVID-19 } \\
\text { infected an average of } 2 \text { to } 3 \text { other people. This reproduction number is similar to } \\
\text { influenza and quite different from that of viruses that are well known to spread via } \\
\text { aerosols such as measles, which has a reproduction number closer to } 18 \text {. Considering } \\
\text { that most people with COVID-19 are contagious for about one week, a reproduction } \\
\text { number of } 2 \text { to } 3 \text { is quite small given the large number of interactions, crowds, and } \\
\text { personal contacts that most people have under normal circumstances within a seven- } \\
\text { day period. }\end{array}$ \\
\hline Lewis, D. & 2020 & $\begin{array}{l}\text { Is the coronavirus airborne? } \\
\text { Experts can't agree. Nature. }\end{array}$ & $\begin{array}{l}\text { Health officials say the virus is transported only through droplets that are coughed or } \\
\text { sneezed out-either directly, or on objects. But some scientists say there is } \\
\text { preliminary evidence that airborne transmission-in which the disease spreads in the } \\
\text { much smaller particles from exhaled air, known as aerosols-is occurring, and that } \\
\text { precautions, such as increasing ventilation indoors, should be recommended to reduce } \\
\text { the risk of infection. }\end{array}$ \\
\hline Li, Q. et al. & 2020 & $\begin{array}{l}\text { Early Transmission Dynamics in } \\
\text { Wuhan, China, of Novel } \\
\text { Coronavirus-Infected } \\
\text { Pneumonia. The New England } \\
\text { Journal of Medicine. }\end{array}$ & $\begin{array}{l}\text { The mean incubation period was } 5.2 \text { days }(95 \% \mathrm{Cl}, 4.1 \text { to } 7.0) \text {, with the } 95 \text { th percentile } \\
\text { of the distribution at } 12.5 \text { days. In its early stages, the epidemic doubled in size every } \\
7.4 \text { days. With a mean serial interval of } 7.5 \text { days ( } 95 \% \mathrm{Cl}, 5.3 \text { to } 19) \text {, the basic } \\
\text { reproductive number was estimated to be } 2.2(95 \% \mathrm{Cl}, 1.4 \text { to } 3.9) \text {. }\end{array}$ \\
\hline Li, W. et al. & 2020 & $\begin{array}{l}\text { The characteristics of household } \\
\text { transmission of COVID-19. } \\
\text { Clinical Infectious Diseases. }\end{array}$ & $\begin{array}{l}\text { Secondary transmission of SARS-CoV-2 developed in } 64 \text { of } 392 \text { household contacts } \\
(16.3 \%) \text {. The secondary attack rate to children was } 4 \% \text { compared with } 17.1 \% \text { for } \\
\text { adults. The secondary attack rate to the contacts within the households with index } \\
\text { patients quarantined by themselves since onset of symptoms was } 0 \% \text { compared with } \\
16.9 \% \text { for contacts without quarantined index patients. The secondary attack rate to } \\
\text { contacts who were spouses of index cases was } 27.8 \% \text { compared with } 17.3 \% \text { for other } \\
\text { adult members in the households. The secondary attack rate of SARS-CoV- } 2 \text { in } \\
\text { household is } 16.3 \% \text {. Age of household contacts and spousal relationship to the index } \\
\text { case are risk factors for transmission of SARS-CoV- } 2 \text { within a household. Quarantine of }\end{array}$ \\
\hline
\end{tabular}




\begin{tabular}{|c|c|c|c|}
\hline & & & $\begin{array}{l}\text { index patients at home since onset of symptoms is useful to prevent the transmission } \\
\text { of SARS-Co-2 within a household. }\end{array}$ \\
\hline Li, Y. et al. & 2020 & $\begin{array}{l}\text { Evidence for probable aerosol } \\
\text { transmission of SARS-CoV-2 in a } \\
\text { poorly ventilated restaurant. } \\
\text { (Preprint). }\end{array}$ & $\begin{array}{l}\text { Three families (A, B, C), } 10 \text { members of which were subsequently found to have been } \\
\text { infected with SARS-CoV- } 2 \text { at this time, or previously, ate lunch at Restaurant X on } \\
\text { Chinese New Year's Eve (January } 24,2020 \text { ) at three neighboring tables. Subsequently, } \\
\text { three members of family B and two members of family C became infected with SARS- } \\
\text { CoV-2, whereas none of the waiters or } 68 \text { patrons at the remaining } 15 \text { tables became } \\
\text { infected. During this occasion, the ventilation rate was } 0.75-1.04 \text { L/s per person. No } \\
\text { close contact or fomite contact was observed, aside from back-to-back sitting by some } \\
\text { patrons. Our results show that the infection distribution is consistent with a spread } \\
\text { pattern representative of exhaled virus-laden aerosols. Aerosol transmission of SARS- } \\
\text { CoV- } 2 \text { due to poor ventilation may explain the community spread of COVID-19. }\end{array}$ \\
\hline $\begin{array}{l}\text { Lipsitch, Marc, } \\
\text { Swerdlow, David L, } \\
\text { and Finelli, Lyn }\end{array}$ & 2020 & $\begin{array}{l}\text { Defining the Epidemiology of } \\
\text { Covid-19 - Studies Needed. The } \\
\text { New England Journal of } \\
\text { Medicine. }\end{array}$ & $\begin{array}{l}\text { First, what is the full spectrum of disease severity (which can range from } \\
\text { asymptomatic, to symptomatic-but-mild, to severe, to requiring hospitalization, to } \\
\text { fatal)? Second, how transmissible is the virus? Third, who are the infectors-how do } \\
\text { the infected person's age, the severity of illness, and other characteristics of a case } \\
\text { affect the risk of transmitting the infection to others? Of vital interest is the role that } \\
\text { asymptomatic or presymptomatic infected persons play in transmission. When and for } \\
\text { how long is the virus present in respiratory secretions? And fourth, what are the risk } \\
\text { factors for severe illness or death? And how can we identify groups most likely to have } \\
\text { poor outcomes so that we can focus prevention and treatment efforts? }\end{array}$ \\
\hline Liu, Y. et al. & 2020 & $\begin{array}{l}\text { Aerodynamic Characteristics } \\
\text { and RNA Concentration of SARS- } \\
\text { CoV-2 Aerosol in Wuhan } \\
\text { Hospitals during COVID-19 } \\
\text { Outbreak. (Preprint). }\end{array}$ & $\begin{array}{l}\text { The ICU, critical care unit, and general patient rooms inside Renmin, and the patient } \\
\text { hall inside Fangcang had undetectable or low airborne SARS-CoV-2 concentration but } \\
\text { deposition samples from inside the ICU and air sample in Fangcang patient toilet } \\
\text { tested positive. The airborne SARS-CoV- } 2 \text { in Fangcang Medical Staff Area had bimodal } \\
\text { distribution with higher concentration than those in Renmin during the outbreak but } \\
\text { turned negative after patient number was reduced and rigorous sanitization was } \\
\text { implemented. Public areas had undetectable airborne SARS-CoV-2 concentration but } \\
\text { obviously increased with accumulating crowd flow. }\end{array}$ \\
\hline
\end{tabular}




\begin{tabular}{|c|c|c|c|}
\hline Liu, Y. et al. & 2020 & $\begin{array}{l}\text { Aerodynamic analysis of SARS- } \\
\text { CoV-2 in two Wuhan hospitals. } \\
\text { Nature. }\end{array}$ & $\begin{array}{l}\text { Investigated the aerodynamic nature of SARS-CoV- } 2 \text { by measuring viral RNA in } \\
\text { aerosols in different areas of two Wuhan hospitals during the outbreak of COVID-19 in } \\
\text { 2020. The concentration of SARS-CoV- } 2 \text { RNA in aerosols that was detected in isolation } \\
\text { wards and ventilated patient rooms was very low, but it was higher in the toilet areas } \\
\text { used by the patients. Levels of airborne SARS-CoV-2 RNA in the most public areas were } \\
\text { undetectable, except in two areas that were prone to crowding. We found that some } \\
\text { medical staff areas initially had high concentrations of viral RNA with aerosol size } \\
\text { distributions that showed peaks in the }<1.0 \mu m \text { and/or }>1.0 \text { regions; however, these } \\
\text { levels were reduced to undetectable levels after implementation of rigorous } \\
\text { sanitization procedures. Although we have not established the infectivity of the virus } \\
\text { detected in these hospital areas, we propose that SARS-CoV-2 may have the potential } \\
\text { to be transmitted through aerosols. Our results indicate that room ventilation, open } \\
\text { space, sanitization of protective apparel, and proper use and disinfection of toilet } \\
\text { areas can effectively limit the concentration of SARS-CoV-2 RNA in aerosols. }\end{array}$ \\
\hline Luo, L. et al. & 2020 & $\begin{array}{l}\text { Modes of contact and risk of } \\
\text { transmission in COVID-19 } \\
\text { among close contacts. Annals of } \\
\text { Internal Medicine. }\end{array}$ & $\begin{array}{l}\text { The proportion of asymptomatic and mild infections account for almost half of the } \\
\text { confirmed cases among close contacts. The household contacts were the main } \\
\text { transmission mode, and clinically more severe cases were more likely to pass the } \\
\text { infection to their close contacts. Generally, the secondary cases were clinically milder } \\
\text { than those of source cases. }\end{array}$ \\
\hline Luo, W., et al. & 2020 & $\begin{array}{l}\text { The role of absolute humidity on } \\
\text { transmission rates of the COVID- } \\
19 \text { outbreak. (Preprint). }\end{array}$ & $\begin{array}{l}\text { Sustained transmission and rapid (exponential) growth of cases are possible over a } \\
\text { range of humidity conditions ranging from cold and dry provinces in China, to tropical } \\
\text { locations, such as Singapore. Changes in weather alone (i.e., increase of temperature } \\
\text { and humidity as spring and summer months arrive in the North Hemisphere) will not } \\
\text { necessarily lead to declines in case counts without the implementation of extensive } \\
\text { public health interventions. }\end{array}$ \\
\hline Luo, Wei et al. & 2020 & $\begin{array}{l}\text { The role of absolute humidity on } \\
\text { transmission rates of the COVID- } \\
19 \text { outbreak. (Preprint). }\end{array}$ & $\begin{array}{l}\text { Here, we examine province-level variability of the basic reproductive numbers of } \\
\text { COVID-19 across China and find that changes in weather alone (i.e., increase of } \\
\text { temperature and humidity as spring and summer months arrive in the Northern }\end{array}$ \\
\hline
\end{tabular}




\begin{tabular}{|c|c|c|c|}
\hline & & & $\begin{array}{l}\text { Hemisphere) will not necessarily lead to declines in COVID-19 case counts without the } \\
\text { implementation of extensive public health interventions. }\end{array}$ \\
\hline Ma, Y. et al. & 2020 & $\begin{array}{l}\text { Effects of temperature variation } \\
\text { and humidity on the mortality of } \\
\text { COVID-19 in Wuhan. Science of } \\
\text { the Total Environment. }\end{array}$ & $\begin{array}{l}\text { A positive association with COVID-19 mortality was observed for diurnal temperature } \\
\text { range }(r=0.44) \text {, but negative association for relative humidity }(r=-0.32) \text {. In addition, } \\
\text { each } 1 \text {-unit increase in diurnal temperature range was only associated with a } 2.92 \% \\
(95 \% \mathrm{Cl}: 0.61 \%, 5.28 \%) \text { increase in COVID-19 mortality at lag } 3 \text {. However, both per-1- } \\
\text { unit increase of temperature and absolute humidity were related to the decreased } \\
\text { COVID-19 mortality at lag } 3 \text { and lag } 5 \text {, respectively. }\end{array}$ \\
\hline $\begin{array}{l}\text { Minnesota } \\
\text { Department of } \\
\text { Health (MDH) }\end{array}$ & 2020 & $\begin{array}{l}\text { Airborne Infectious Disease } \\
\text { Management: Methods for } \\
\text { Temporary Negative Pressure } \\
\text { Isolation. }\end{array}$ & Planning to develop a 12-hour response to implement containment measures. \\
\hline $\begin{array}{l}\text { Mikszewski, Alex et } \\
\text { al. }\end{array}$ & 2020 & $\begin{array}{l}\text { Airborne Infection Risk } \\
\text { Calculator. CUNY. }\end{array}$ & $\begin{array}{l}\text { The Airborne Infection Risk Calculator (AIRC) is an airborne contagion modeling tool } \\
\text { programmed in Microsoft Excel and designed to assist facility managers, building } \\
\text { engineers, and public and occupational health professionals in prospectively } \\
\text { evaluating individual infection and community transmission risks associated with } \\
\text { specific indoor environments. AIRC can help users address two primary questions } \\
\text { related to the risks associated with occupying an indoor space when community } \\
\text { transmission of an infectious airborne pathogen, such as SARS-CoV-2, is occurring: } 1 \text {. } \\
\text { What is the potential infection risk associated with varying lengths of stay in the } \\
\text { space? 2. What number of occupants helps maintain a basic reproduction number (R0) } \\
\text { less than one to prevent the exposure from further contributing to disease spread in } \\
\text { the population? }\end{array}$ \\
\hline
\end{tabular}




\begin{tabular}{|c|c|c|c|}
\hline Miller et al. & 2020 & $\begin{array}{l}\text { Transmission and risk factors of } \\
\text { COVID-19. Cleveland Clinic. }\end{array}$ & $\begin{array}{l}\text { The reproductive number (R0) for SARS-CoV- } 2 \text { is } 2.28 \text { compared to } 0.9 \text { to } 2.1 \text { for } \\
\text { influenza. Viral shedding can occur up to five days before symptom onset. SARS-CoV-2, } \\
\text { the virus that causes COVID-19, is transmitted through respiratory secretions and } \\
\text { saliva. The virus can also live for short periods of time (one to several hours) on } \\
\text { fomites such as doorknobs, handrails, and tables. Aerosolization of the virus can occur } \\
\text { during procedures including bronchoscopy, endotracheal intubation, and } \\
\text { administration of nebulized treatments. Asymptomatic shedding of the virus does } \\
\text { occur and may account for up to } 60 \% \text { of cases. Risk factors for a more severe course of } \\
\text { COVID-19 include age } 65 \text { and older, living in a nursing home or LTC facility, chronic } \\
\text { lung disease, and others. }\end{array}$ \\
\hline Miller, Shelly L. et al. & 2017 & $\begin{array}{l}\text { Implementing a negative- } \\
\text { pressure isolation ward for a } \\
\text { surge in airborne infectious } \\
\text { patients. American Journal of } \\
\text { Infection Control. }\end{array}$ & $\begin{array}{l}\text { During an infectious disease outbreak, the number of patients needing health care } \\
\text { services may exceed available negative-pressure isolation room capacity. To test one } \\
\text { method of increasing hospital surge capacity, a temporary negative-pressure isolation } \\
\text { ward was established at a fully functioning hospital. Negative pressure was achieved in } \\
\text { a } 30 \text {-bed hospital ward by adjusting the ventilation system. Differential pressure was } \\
\text { continuously measured at } 22 \text { locations, and ventilation airflow was characterized } \\
\text { throughout the ward. The pressure on the test ward relative to the main hospital } \\
\text { hallway was - } 29 \text { Pa on average, approximately } 10 \text { times higher than the CDC guidance } \\
\text { for airborne infection control. No occurrences of pressure reversal occurred at the } \\
\text { entrances to the ward, even when staff entered the ward. Pressures within the ward } \\
\text { changed, with some rooms becoming neutrally or slightly positively pressurized. This } \\
\text { study showed that establishing a temporary negative-pressure isolation ward is an } \\
\text { effective method to increase surge capacity in a hospital. }\end{array}$ \\
\hline $\begin{array}{l}\text { Morawska, Lidia et } \\
\text { al. }\end{array}$ & 2020 & $\begin{array}{l}\text { It is Time to Address Airborne } \\
\text { Transmission of COVID-19. } \\
\text { Clinical Infectious Diseases. }\end{array}$ & $\begin{array}{l}\text { A } 5-\mu m \text { droplet will travel tens of meters, much greater than the scale of a typical } \\
\text { room, while settling from a height of } 1.5 \mathrm{~m} \text { to the floor. Several retrospective studies } \\
\text { conducted after the SARS-CoV- } 1 \text { epidemic demonstrated that airborne transmission } \\
\text { was the most likely mechanism explaining the spatial pattern of infections. } \\
\text { Retrospective analysis has shown the same for SARS-CoV-2. Many studies conducted } \\
\text { on the spread of other viruses, including respiratory syncytial virus, MERS-CoV, and }\end{array}$ \\
\hline
\end{tabular}




\begin{tabular}{|c|c|c|c|}
\hline & & & $\begin{array}{l}\text { influenza, show that viable airborne viruses can be exhaled and/or detected in the } \\
\text { indoor environment of infected patients. }\end{array}$ \\
\hline $\begin{array}{l}\text { Morowska, Lidia et } \\
\text { al. }\end{array}$ & 2020 & $\begin{array}{l}\text { How can airborne transmission } \\
\text { of COVID-19 indoors be } \\
\text { minimised? Environment } \\
\text { International. }\end{array}$ & $\begin{array}{l}\text { Inhaling small airborne droplets is probable as a third route of infection, in addition to } \\
\text { more widely recognized transmission via larger respiratory droplets and direct contact } \\
\text { with infected people or contaminated surfaces. While uncertainties remain regarding } \\
\text { the relative contributions of the different transmission pathways, we argue that } \\
\text { existing evidence is sufficiently strong to warrant engineering controls targeting } \\
\text { airborne transmission as part of an overall strategy to limit infection risk indoors. } \\
\text { Appropriate building engineering controls include sufficient and effective ventilation, } \\
\text { possibly enhanced by particle filtration and air disinfection, avoiding air recirculation, } \\
\text { and avoiding overcrowding. }\end{array}$ \\
\hline $\begin{array}{l}\text { National Air Filtration } \\
\text { Association (NAFA) }\end{array}$ & 2020 & $\begin{array}{l}\text { COVID-19 Special Feature: HVAC } \\
\text { Filtration And COVID-19. }\end{array}$ & $\begin{array}{l}\text { Filtration in building HVAC systems can be a part of an overall risk mitigation approach. } \\
\text { In order for filters to have any impact on infectious disease transmission, transmission } \\
\text { has to occur through the airborne route. High-efficiency filters may be appropriate, } \\
\text { but they can also be counterproductive. A high-efficiency filter may have a high initial } \\
\text { pressure drop and cause more air to bypass the filter. A high-pressure drop filter can } \\
\text { also diminish the amount of air supplied into the environment, making the filter less } \\
\text { effective as well as causing other problems with other parts of the HVAC system. In } \\
\text { many residential and light commercial systems, the fan in the system does not run } \\
\text { very often and the efficiency of the filter may not be as important as it could be. }\end{array}$ \\
\hline $\begin{array}{l}\text { Nishiura, } \mathrm{H} \text {. } \\
\text { et al. }\end{array}$ & 2020 & $\begin{array}{l}\text { Closed environments facilitate } \\
\text { secondary transmission of } \\
\text { coronavirus disease } 2019 . \\
\text { (Preprint). }\end{array}$ & $\begin{array}{l}\text { Commissioned by the Minister of the Ministry of Health, Labour, and Welfare of Japan, } \\
\text { we collected secondary transmission data with the aim of identifying high-risk } \\
\text { transmission settings. We show that closed environments contribute to secondary } \\
\text { transmission of COVID-19 and promote superspreading events. Closed environments } \\
\text { are consistent with large-scale COVID-19 transmission events such as that of the ski } \\
\text { chalet-associated cluster in France and the church- and hospital-associated clusters in } \\
\text { South Korea. Our findings are also consistent with the declining incidence of COVID-19 } \\
\text { cases in China, as gathering in closed environments was prohibited in the wake of the } \\
\text { rapid spread of the disease. Reduction of unnecessary close contact in closed } \\
\text { environments may help prevent large case clusters and superspreading events. }\end{array}$ \\
\hline
\end{tabular}




\begin{tabular}{|c|c|c|c|}
\hline $\begin{array}{l}\text { Neher, Richard A. et } \\
\text { al. }\end{array}$ & 2020 & $\begin{array}{l}\text { Potential impact of seasonal } \\
\text { forcing on a SARS-CoV-2 } \\
\text { pandemic. Swiss Medical } \\
\text { Weekly. }\end{array}$ & $\begin{array}{l}\text { While the uncertainty in parameters is large, the scenarios we explore show that } \\
\text { transient reductions in the incidence rate might be due to a combination of seasonal } \\
\text { variation and infection control efforts but do not necessarily mean the epidemic is } \\
\text { contained. Seasonal forcing on SARS-CoV-2 should thus be taken into account in the } \\
\text { further monitoring of the global transmission. The likely aggregated effect of seasonal } \\
\text { variation, infection control measures and transmission rate variation is a prolonged } \\
\text { pandemic wave with lower prevalence at any given time, thereby providing a window } \\
\text { of opportunity for better preparation of health care systems. }\end{array}$ \\
\hline $\begin{array}{l}\text { Oliveiros, Barbara et } \\
\text { al. }\end{array}$ & 2020 & $\begin{array}{l}\text { Role of temperature and } \\
\text { humidity in the modulation of } \\
\text { the doubling time of COVID-19 } \\
\text { cases. (Preprint). }\end{array}$ & $\begin{array}{l}\text { Results indicate that the doubling time correlates positively with temperature and } \\
\text { inversely with humidity, suggesting that a decrease in the rate of progression of } \\
\text { COVID-19 with the arrival of spring and summer in the Northern Hemisphere. A } 20^{\circ} \mathrm{C} \\
\text { increase is expected to delay the doubling time in } 1.8 \text { days. Those variables explain } \\
18 \% \text { of the variation in disease doubling time; the remaining } 82 \% \text { may be related to } \\
\text { containment measures, general health policies, population density, transportation, or } \\
\text { cultural aspects. }\end{array}$ \\
\hline Ong, S. et al. & 2020 & $\begin{array}{l}\text { Surface Environmental, and } \\
\text { Personal Protective Equipment } \\
\text { Contamination by SARS-CoV-2 } \\
\text { From a Symptomatic Patient. } \\
\text { Journal of the American Medical } \\
\text { Association. }\end{array}$ & $\begin{array}{l}\text { There was extensive environmental contamination by } 1 \text { SARS-CoV- } 2 \text { patient with mild } \\
\text { upper respiratory tract involvement. Toilet bowl and sink samples were positive, } \\
\text { suggesting that viral shedding in stool could be a potential route of transmission. Post- } \\
\text { cleaning samples were negative, suggesting that current decontamination measures } \\
\text { are sufficient. }\end{array}$ \\
\hline Pastorino, B. et al. & 2020 & $\begin{array}{l}\text { Prolonged viability of SARS- } \\
\text { CoV-2 in fomites. Emerging } \\
\text { Infectious Diseases. }\end{array}$ & $\begin{array}{l}\text { In conclusion, we showed that a moderate protein concentration in droplets markedly } \\
\text { increased the infectivity of SARS-CoV-2, suggesting that a protein rich medium like } \\
\text { airway secretions could protect the virus when it is expelled and may enhance its } \\
\text { persistence and transmission by contaminated fomites. Accordingly, it is plausible that } \\
\text { fomites infected with SARS-CoV-2 play a key role in the indirect transmission of COVID- } \\
\text { 19. This finding supports surface cleaning as a necessary action that should be } \\
\text { enforced and repeated because it may play a key role in halting SARS-CoV-2 } \\
\text { transmission and mitigating the COVID-19 pandemic. }\end{array}$ \\
\hline
\end{tabular}




\begin{tabular}{|c|c|c|c|}
\hline Peng, Shi et al. & 2020 & $\begin{array}{l}\text { The impact of temperature and } \\
\text { absolute humidity on the } \\
\text { coronavirus disease } 2019 \\
\text { (COVID-19) outbreak - evidence } \\
\text { from China. Science of the Total } \\
\text { Environment. }\end{array}$ & $\begin{array}{l}\text { The number of new confirmed COVID- } 19 \text { cases in mainland China peaked on February } \\
1,2020 \text {. COVID-19 daily incidence were lowest at }-10^{\circ} \mathrm{C} \text { and highest at } 10^{\circ} \mathrm{C} \text {, while the } \\
\text { maximum incidence was observed at the absolute humidity of approximately } 7 \mathrm{~g} / \mathrm{m}^{3} \text {. } \\
\text { COVID-19 incidence changed with temperature as daily incidence decreased when the } \\
\text { temperature rose. No significant association between COVID- } 19 \text { incidence and } \\
\text { absolute humidity was observed in distributed lag nonlinear models. Additionally, a } \\
\text { modified susceptible-exposed-infectious-recovered (M-SEIR) model confirmed that } \\
\text { transmission rate decreased with the increase of temperature, leading to further } \\
\text { decrease of infection rate and outbreak scale. The report concludes that temperature } \\
\text { is an environmental driver of the COVID-19 outbreak in China. Lower and higher } \\
\text { temperatures might be positive to decrease the COVID-19 incidence. M-SEIR models } \\
\text { help to better evaluate environmental and social impacts on COVID-19. }\end{array}$ \\
\hline Qian, Hua et al. & 2020 & $\begin{array}{l}\text { Indoor transmission of SARS- } \\
\text { CoV-2. Indoor Air. }\end{array}$ & $\begin{array}{l}318 \text { outbreaks with three or more cases were identified, involving } 1,245 \text { confirmed } \\
\text { cases in } 120 \text { prefectural cities. We divided the venues in which the outbreaks occurred } \\
\text { into six categories: homes, transport, food, entertainment, shopping, and } \\
\text { miscellaneous. Among the identified outbreaks, } 53.8 \% \text { involved three cases, } 26.4 \% \\
\text { involved four cases, and only } 1.6 \% \text { involved ten or more cases. Home outbreaks were } \\
\text { the dominant category ( } 254 \text { of } 318 \text { outbreaks; } 79.9 \% \text { ), followed by transport (108; } \\
34.0 \% \text {; note that many outbreaks involved more than one venue category). Most } \\
\text { home outbreaks involved three to five cases. We identified only a single outbreak in an } \\
\text { outdoor environment, which involved two cases. All identified outbreaks of three or } \\
\text { more cases occurred in an indoor environment, which confirms that sharing indoor } \\
\text { space is a major SARS-CoV- } 2 \text { infection risk. }\end{array}$ \\
\hline Qiu, Yun et al. & 2020 & $\begin{array}{l}\text { Impacts of social and economic } \\
\text { factors on the transmission of } \\
\text { coronavirus disease (COVID-19) } \\
\text { in China. Journal of Population } \\
\text { Economics. }\end{array}$ & $\begin{array}{l}\text { We rely on meteorological data to construct instrumental variables for the } \\
\text { endogenous variables. The National Oceanic and Atmospheric Administration provides } \\
\text { average, maximum, and minimum temperatures, air pressure, average and maximum } \\
\text { wind speeds, precipitation, snowfall amount, and dew point for } 362 \text { weather stations } \\
\text { at the daily level in China. To merge the meteorological variables with the number of } \\
\text { new cases of COVID-19, we first calculate daily weather variables for each city on each } \\
\text { day from } 2019 \text { December to } 2020 \text { February from station-level weather records }\end{array}$ \\
\hline
\end{tabular}




\begin{tabular}{|c|c|c|c|}
\hline & & & $\begin{array}{l}\text { following the inverse-distance weighting method. Second, we match the daily weather } \\
\text { variables to the number of new cases of COVID-19 based on city name and date. }\end{array}$ \\
\hline Rabenau, H. et al. & 2020 & $\begin{array}{l}\text { Efficacy of various disinfectants } \\
\text { against SARS coronavirus. } \\
\text { Journal of Hospital Infection. }\end{array}$ & $\begin{array}{l}\text { Investigated eight disinfectants for their activity against SARS-CoV according to prEN } \\
\text { 14476. In summary, SARS-CoV can be inactivated quite easily with many commonly } \\
\text { used disinfectants. }\end{array}$ \\
\hline $\begin{array}{l}\text { Riediker, Michael et } \\
\text { al. }\end{array}$ & 2020 & $\begin{array}{l}\text { Estimation of Viral Aerosol } \\
\text { Emissions From Simulated } \\
\text { Individuals With Asymptomatic } \\
\text { to Moderate Coronavirus } \\
\text { Disease 2019. JAMA. }\end{array}$ & $\begin{array}{l}\text { The estimated concentrations in a room with an individual who was coughing } \\
\text { frequently were very high, with a maximum of } 7.44 \text { million viral copies } / \mathrm{m}^{3} \text { from an } \\
\text { individual who was a high emitter. However, regular breathing from an individual who } \\
\text { was a high emitter was modeled to result in lower room concentrations of up to } 1,248 \\
\text { copies } / \mathrm{m}^{3} \text {. }\end{array}$ \\
\hline $\begin{array}{l}\text { Santarpia, J. } \\
\text { et al. }\end{array}$ & 2020 & $\begin{array}{l}\text { Transmission Potential of SARS- } \\
\text { CoV-2 in Viral Shedding } \\
\text { Observed at the University of } \\
\text { Nebraska Medical Center. } \\
\text { (Preprint). }\end{array}$ & $\begin{array}{l}\text { During the initial isolation of } 13 \text { individuals confirmed positive with COVID-19 } \\
\text { infection, air and surface samples were collected in } 11 \text { isolation rooms to examine viral } \\
\text { shedding from isolated individuals. While all individuals were confirmed positive for } \\
\text { SARS-CoV-2, symptoms and viral shedding to the environment varied considerably. } \\
\text { Many commonly used items, toilet facilities, and air samples had evidence of viral } \\
\text { contamination, indicating that SARS-CoV-2 is shed to the environment as expired } \\
\text { particles, during toileting, and through contact with fomites. Disease spread through } \\
\text { both direct (droplet and person-to-person) as well as indirect contact (contaminated } \\
\text { objects and airborne transmission) are indicated, supporting the use of airborne } \\
\text { isolation precautions. }\end{array}$ \\
\hline Schoen, Lawrence J. & 2020 & $\begin{array}{l}\text { Guidance for Building } \\
\text { Operations During the COVID-19 } \\
\text { Pandemic. ASHRAE Journal. }\end{array}$ & $\begin{array}{l}\text { Recommendations in this guidance document include: } \\
\text { - Increase outdoor air ventilation (use caution in highly polluted areas); with a lower } \\
\text { population in the building; this increases the effective dilution ventilation per person } \\
\text { - Disable demand-controlled ventilation } \\
\text { - Further open minimum outdoor air dampers, as high as } 100 \% \text {, thus eliminating } \\
\text { recirculation (in the mild weather season, this need not affect thermal comfort or } \\
\text { humidity, but clearly becomes more difficult in extreme weather) }\end{array}$ \\
\hline
\end{tabular}




\begin{tabular}{|c|c|c|c|}
\hline & & & $\begin{array}{l}\text { - Improve central air filtration to the MERV- } 13 \text { or the highest compatible with the } \\
\text { filter rack, and seal edges of the filter to limit bypass } \\
\text { - Keep systems running longer hours, if possible } 24 / 7 \text {, to enhance the two actions } \\
\text { above } \\
\text { - Consider portable room air cleaners with HEPA filters } \\
\text { - Consider UVGI (ultraviolet germicidal irradiation) protecting occupants from } \\
\text { radiation particularly in high-risk spaces such as waiting rooms. }\end{array}$ \\
\hline $\begin{array}{l}\text { Smither, Sophie J. et } \\
\text { al. }\end{array}$ & 2020 & $\begin{array}{l}\text { Experimental Aerosol Survival of } \\
\text { SARS-CoV-2 in Artificial Saliva } \\
\text { and Tissue. Emerging Microbes } \\
\text { and Infections. }\end{array}$ & $\begin{array}{l}\text { SARS-CoV-2, the causative agent of the COVID-19 pandemic, may be transmitted via } \\
\text { airborne droplets or contact with surfaces onto which droplets have deposited. In this } \\
\text { study, the ability of SARS-CoV- } 2 \text { to survive in the dark, at two different relative } \\
\text { humidity values and within artificial saliva, a clinically relevant matrix, was } \\
\text { investigated. SARS-CoV- } 2 \text { was found to be stable, in the dark, in a dynamic small } \\
\text { particle aerosol under the four experimental conditions we tested and viable virus } \\
\text { could still be detected after } 90 \text { minutes. The decay rate and half-life were determined; } \\
\text { decay rates ranged from } 0.4 \% \text { to } 2.27 \% \text { per minute and the half-lives ranged from } 30 \\
\text { to } 177 \text { minutes for the different conditions. This information can be used for advice } \\
\text { and modelling and potential mitigation strategies. }\end{array}$ \\
\hline $\begin{array}{l}\text { Stadnytskyi, Valentyn } \\
\text { et al. }\end{array}$ & 2020 & $\begin{array}{l}\text { The airborne lifetime of small } \\
\text { speech droplets and their } \\
\text { potential importance in SARS- } \\
\text { CoV-2 transmission. } \\
\text { Proceedings of the National } \\
\text { Academy of Sciences of the } \\
\text { United States of America. }\end{array}$ & $\begin{array}{l}\text { Speech droplets generated by asymptomatic carriers of SARS-CoV- } 2 \text { are increasingly } \\
\text { considered to be a likely mode of disease transmission. Highly sensitive laser light } \\
\text { scattering observations have revealed that loud speech can emit thousands of oral } \\
\text { fluid droplets per second. In a closed, stagnant air environment, they disappear from } \\
\text { the window of view with time constants in the range of } 8 \text { to } 14 \text { minutes, which } \\
\text { corresponds to droplet nuclei of } 4 \mu \mathrm{m} \text { diameter, or } 12 \text { - to } 21-\mu \mathrm{m} \text { droplets prior to } \\
\text { dehydration. These observations confirm that there is a substantial probability that } \\
\text { normal speaking causes airborne virus transmission in confined environments. }\end{array}$ \\
\hline $\begin{array}{l}\text { van Doremalen, } \\
\text { Neeltje et al. }\end{array}$ & 2020 & $\begin{array}{l}\text { Aerosol and surface stability of } \\
\text { SARS-CoV-2 compared to SARS- } \\
\text { CoV-1. (Preprint). }\end{array}$ & $\begin{array}{l}\text { We found that the stability of SARS-CoV- } 2 \text { was similar to that of SARS-CoV- } 1 \text { under the } \\
\text { experimental circumstances tested. This indicates that differences in the } \\
\text { epidemiologic characteristics of these viruses probably arise from other factors, } \\
\text { including high viral loads in the upper respiratory tract and the potential for persons }\end{array}$ \\
\hline
\end{tabular}




\begin{tabular}{|c|c|c|c|}
\hline & & & $\begin{array}{l}\text { infected with SARS-CoV-2 to shed and transmit the virus while asymptomatic. Our } \\
\text { results indicate that aerosol and fomite transmission of SARS-CoV-2 is plausible, since } \\
\text { the virus can remain viable and infectious in aerosols for hours and on surfaces up to } \\
\text { days (depending on the inoculum shed). These findings echo those with SARS-CoV-1, in } \\
\text { which these forms of transmission were associated with nosocomial spread and super- } \\
\text { spreading events, and they provide information for pandemic mitigation efforts. }\end{array}$ \\
\hline Wang, Mao et al. & 2020 & $\begin{array}{l}\text { Temperature Significantly } \\
\text { Change COVID-19 Transmission } \\
\text { in } 429 \text { Cities. Science of the Total } \\
\text { Environment. }\end{array}$ & $\begin{array}{l}\text { The study found that, to a certain extent, temperature could significantly change } \\
\text { COVID-19 transmission, and there might be a best temperature for the viral } \\
\text { transmission, which may partly explain why it first broke out in Wuhan. It is suggested } \\
\text { that countries and regions with lower temperatures adopt the strictest control } \\
\text { measures to prevent future reversal. }\end{array}$ \\
\hline Wiberg, Drew & 2020 & $\begin{array}{l}\text { COVID-19 In the Built } \\
\text { Environment. Science Daily. }\end{array}$ & $\begin{array}{l}\text { Aerosolized (airborne) SARS-CoV- } 2 \text { has been shown to have a half-life of approximately } \\
\text { an hour. The virus has a significantly longer half-life once it settles on surfaces or } \\
\text { objects. An increase in outdoor temperature or humidity has not been shown to } \\
\text { significantly decrease current infection rates. Sufficient UV light has, however, been } \\
\text { proven to inactivate the SARS-CoV-2 virus. Copper and cardboard retain viable SARS- } \\
\text { CoV-2 particles with a half-life between } 2 \text { and } 4 \text { hours. Stainless steel and plastic } \\
\text { surfaces retain the virus with a proven half-life of up to } 6.5 \text { hours. }\end{array}$ \\
\hline $\begin{array}{l}\text { World Health } \\
\text { Organization }\end{array}$ & 2020 & $\begin{array}{l}\text { Transmission of SARS-CoV-2: } \\
\text { implications for infection } \\
\text { prevention precautions. }\end{array}$ & $\begin{array}{l}\text { Transmission of SARS-CoV- } 2 \text { can occur through direct, indirect, or close contact with } \\
\text { infected people through infected secretions such as saliva and respiratory secretions } \\
\text { or their respiratory droplets. Respiratory droplets are }>5 \mu \mathrm{m} \text { in diameter whereas } \\
\text { droplets }<5 \mu \mathrm{m} \text { in diameter are referred to as droplet nuclei or aerosols. Airborne } \\
\text { transmission is defined as the spread of an infectious agent caused by the } \\
\text { dissemination of droplet nuclei (aerosols) that remain infectious when suspended in } \\
\text { air over long distances ( }>6 \mathrm{ft} \text {.) and time (several hours). Airborne transmission of SARS- } \\
\text { CoV- } 2 \text { can occur during medical procedures that generate aerosols. World Health } \\
\text { Organization, together with the scientific community, has been actively discussing and } \\
\text { evaluating whether SARS-CoV- } 2 \text { may also spread through aerosols in the absence of } \\
\text { aerosol-generating procedures, particularly in indoor settings with poor ventilation. }\end{array}$ \\
\hline
\end{tabular}




\begin{tabular}{|c|c|c|c|}
\hline Yanfang, Jiang et al. & 2020 & $\begin{array}{l}\text { Clinical Data on Hospital } \\
\text { Environmental Hygiene } \\
\text { Monitoring and Medical Staff } \\
\text { Protection during the } \\
\text { Coronavirus Disease } 2019 \\
\text { Outbreak. (Preprint). }\end{array}$ & $\begin{array}{l}\text { Viruses could be detected on the surfaces of the nurse station in the isolation area } \\
\text { with suspected patients and in the air of the isolation ward with an intensive care } \\
\text { patient. }\end{array}$ \\
\hline Yuwen, Cai et al. & 2020 & $\begin{array}{l}\text { The Effects of "Fangcang, } \\
\text { Huoshenshan, and Leishenshan" } \\
\text { Makeshift Hospitals and } \\
\text { Temperature on the Mortality of } \\
\text { covID-19. Peer J. }\end{array}$ & $\begin{array}{l}\text { Mortality of confirmed cases was found to be significantly correlated with } \\
\text { temperature both in Wuhan }(r=-0.441, P=0.012) \text { and Hubei }(r=-0.440, P=0.012) \text {. } \\
\text { Our findings indicated that both the use of makeshift hospitals and the rise of air } \\
\text { temperature were beneficial to the survival of COVID- } 19 \text { cases. If air temperature rises } \\
1^{\circ} \mathrm{C} \text {, the mortality of confirmed cases would decrease } 0.44 \% \text { and the mortality of } \\
\text { severe cases would decrease } 0.42 \% \text { on average. }\end{array}$ \\
\hline Zhang, John et al. & 2020 & $\begin{array}{l}\text { Study of Viral Filtration } \\
\text { Performance of Residential } \\
\text { HVAC Filters. ASHRAE Journal. }\end{array}$ & $\begin{array}{l}\text { Researchers recently carried out an experimental study to understand the efficacy and } \\
\text { effectiveness of residential HVAC filters at removing airborne virus particles in the } \\
\text { airstream. It concluded that high-efficiency residential HVAC filters were effective at } \\
\text { capturing airborne virus particles in the air passing through the filter. This study } \\
\text { focused on viral filtration of residential HVAC filters with different minimum efficiency } \\
\text { rating values (MERV), e.g., MERV } 5 \text { ( } 30 \% \text { removal efficiency, } 40-\text {-Pa pressure drop), } \\
\text { MERV } 12 \text { ( } 80 \% \text { removal efficiency, } 40-P a \text { pressure drop), and MERV } 14 \text { (95\% removal } \\
\text { efficiency, } 60 \text {-Pa pressure drop). Nebulizer generators produce droplet aerosols with } \\
\text { mass median aerodynamic diameters of } 1 \mu \mathrm{m} \text { to } 3 \mu \mathrm{m} \text {. }\end{array}$ \\
\hline Zhao, Bin et al. & 2020 & $\begin{array}{l}\text { Air purifiers: A supplementary } \\
\text { measure to remove airborne } \\
\text { SARS-CoV-2. (Preprint). }\end{array}$ & $\begin{array}{l}\text { As measured by Liu et al., the peak concentration of SARS-CoV- } 2 \text { aerosols appears in } \\
\text { two distinct size ranges, one in the submicron region with aerodynamic diameter } \\
\text { dominant between } 0.25 \text { and } 1.0 \mu \mathrm{m} \text {, and the other peak in supermicron region with } \\
\text { diameter larger than } 2.5 \mu \mathrm{m} \text {. Such aerosols just fall in the size range that can be } \\
\text { effectively removed by air purifiers. Most air purifiers employ HEPA filters for particles } \\
\text { filtration; the filtration efficiencies of HEPA are high enough to remove such virus- } \\
\text { laden aerosols. According to our previous measurements, the efficiencies of HEPA are }\end{array}$ \\
\hline
\end{tabular}




\begin{tabular}{|l|l|l|l|}
\hline & & $\begin{array}{l}\text { more than } 95 \% \text { for aerosols of diameter between } 0.25 \text { and } 1.0 \mu \mathrm{m} \text { and nearly } 100 \% \text { for } \\
\text { those with diameter larger than } 2.5 \mu \mathrm{m} .\end{array}$ \\
\hline Zhu, Y. et al. & 2020 & $\begin{array}{l}\text { This study introduced a statistical disease transmission model using case symptom } \\
\text { On a Statistical Transmission } \\
\text { Phase of COVID- 19 Outbreak. } \\
\text { Statistics in Biosciences. }\end{array}$ & $\begin{array}{l}\text { provided sensitivity analyses with various assumptions of disease natural history of the } \\
\text { CovID-19. We fitted the transmission model to several publicly available sources of } \\
\text { the outbreak data until 11, February 2020, and estimated lock down intervention } \\
\text { efficacy of Wuhan city. The estimated RO was between 2.7 and 4.2 from plausible } \\
\text { distribution assumptions of the incubation period and relative infectivity over the } \\
\text { infectious period. }\end{array}$ \\
\hline
\end{tabular}




\section{Appendix B. Test Results (Heat Maps)}

Heat maps illustrating the mobility and concentration of DNA-coded tracer aerosol for each test in each test space are shown in Figures $\mathrm{A} 1-\mathrm{A} 8$. The designation $\mathrm{OP}_{1-16}$ represents 16 total aerosol release points in four areas (two resident rooms, staff room, and corridor) for each test space (control and experimental) tested at 30\% and 100\% outdoor air. Similarly, the designation $\mathrm{SP}_{1-48}$ represents 48 aerosol sampling points in four areas of each test space tested at $30 \%$ and $100 \%$ outdoor air, respectively. Aerosol concentrations are denoted by color code (red - high, blue - low) and by the $\log _{10}$ reduction in aerosol concentration as related to the number of DNA copies required by PCR to detect the presence of the tracer aerosol ( $1-$ high, $6-$ low $)$. Figures A9-A10 provide a summary comparing the effect of $30 \%$ and $100 \%$ outdoor air for each sampling point in each test space. 


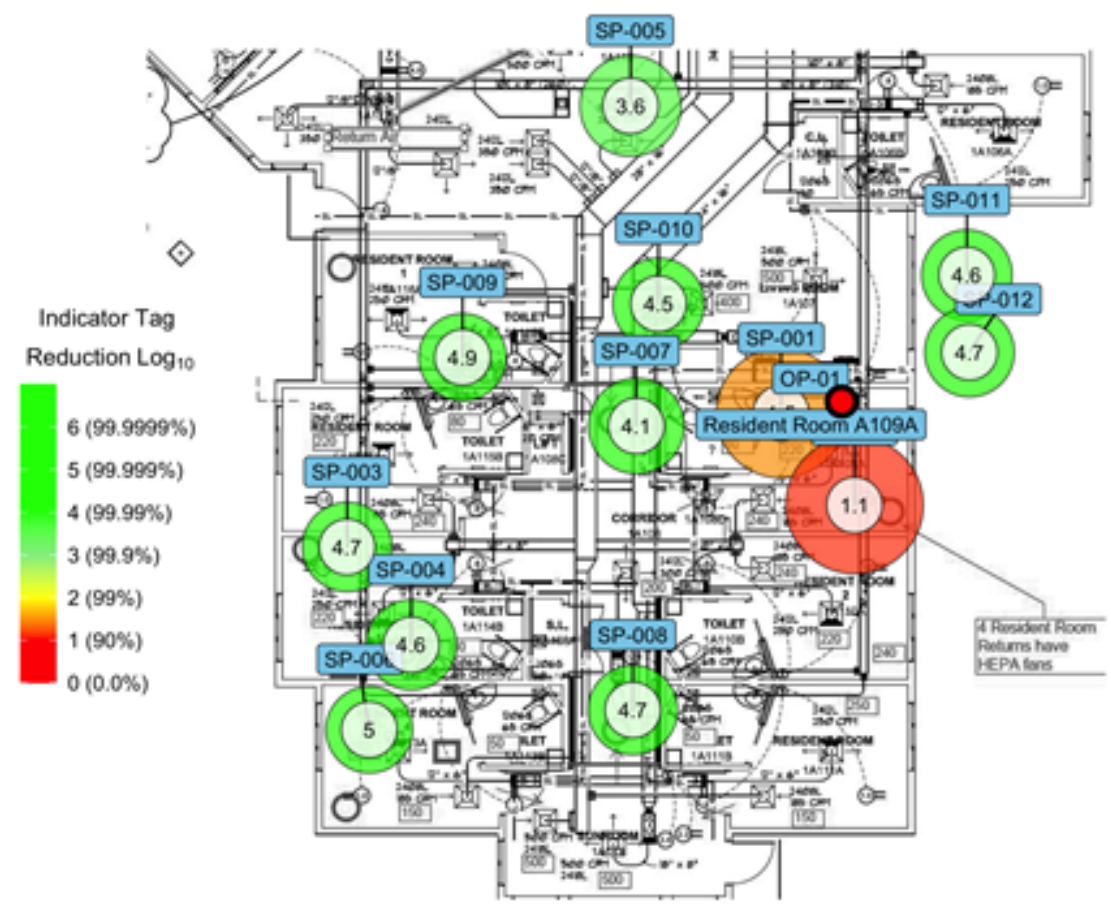

Experimental (isolation) - 30\% outside air (OP-01)

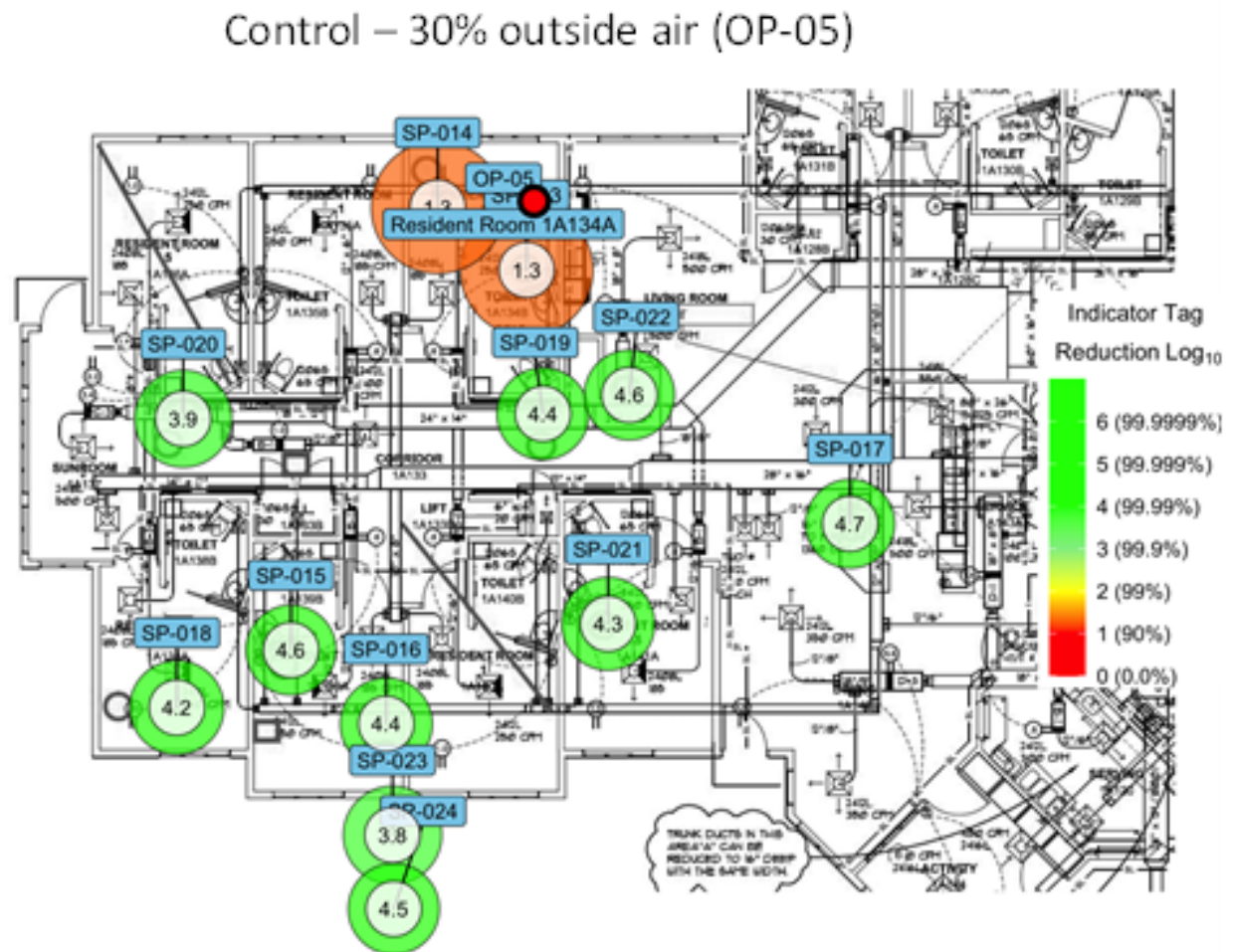

Figure A-1. Experimental (isolation) test space vs. control test space (30\% outside air - resident room 1) 


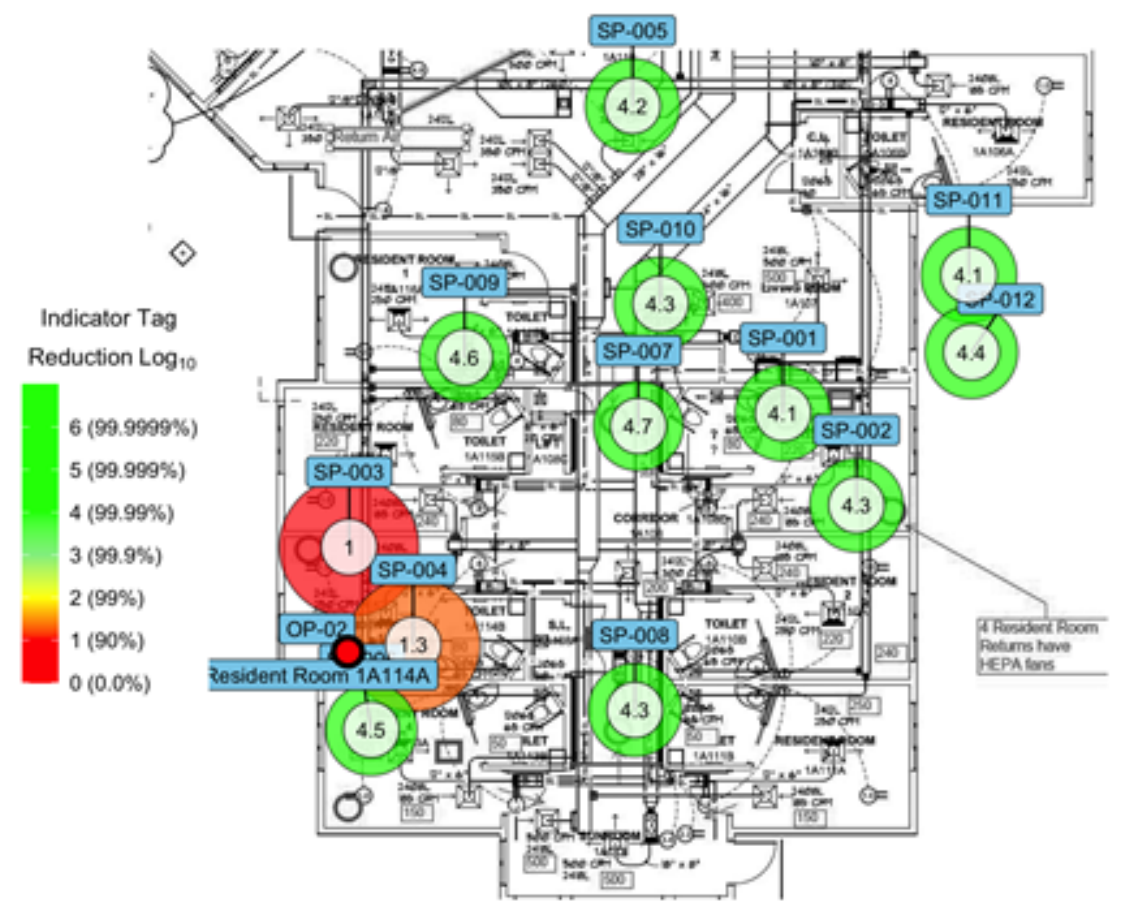

Experimental (isolation) - 30\% outside air (OP-02)

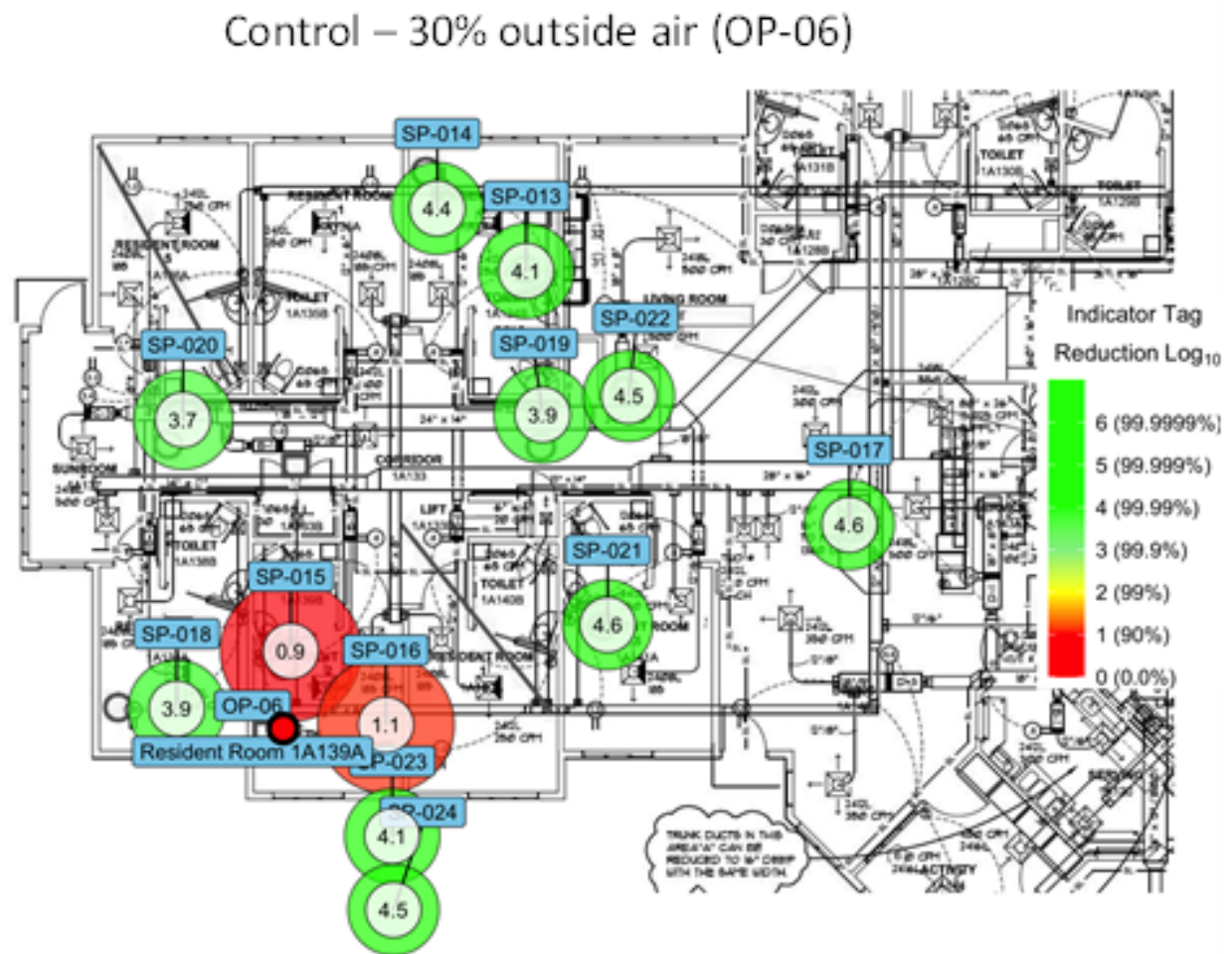

Figure A-2. Experimental (isolation) test space vs. control test space (30\% outside air - resident room 2) 


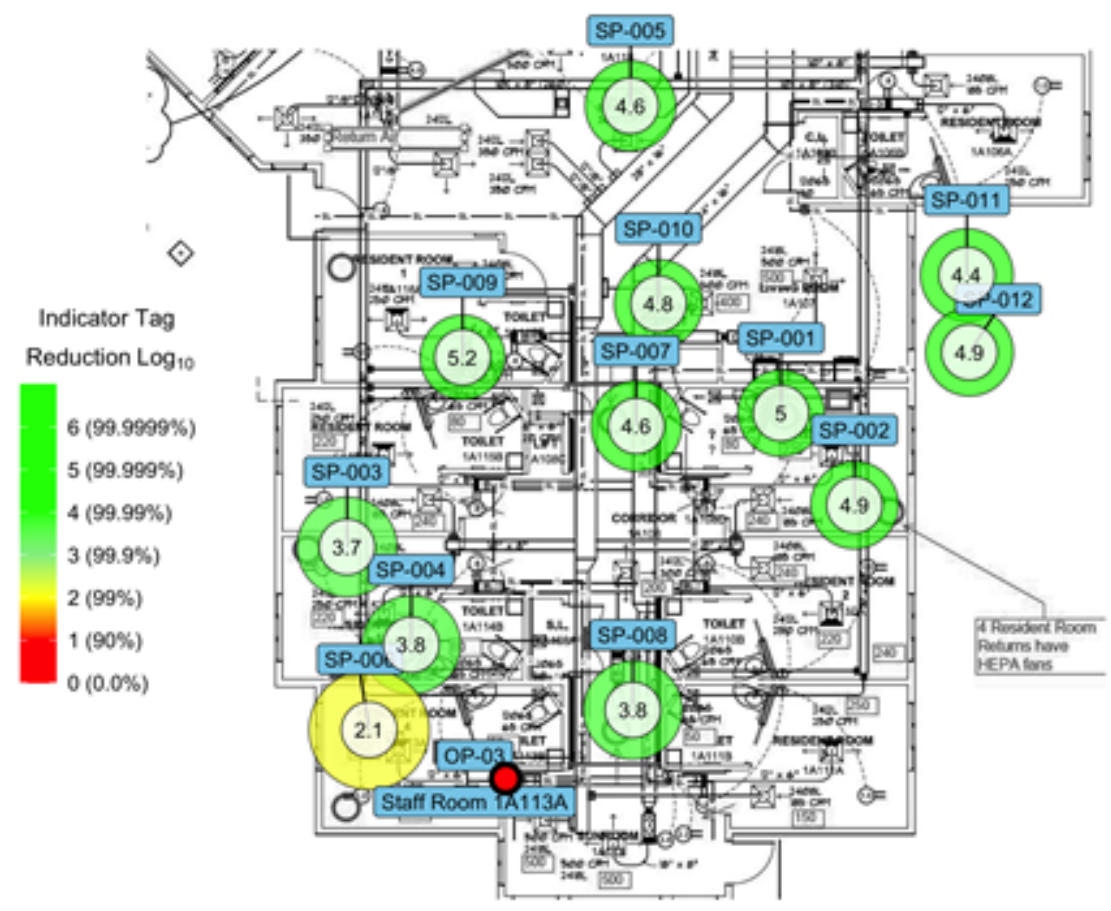

Experimental (isolation) - 30\% outside air (OP-03)

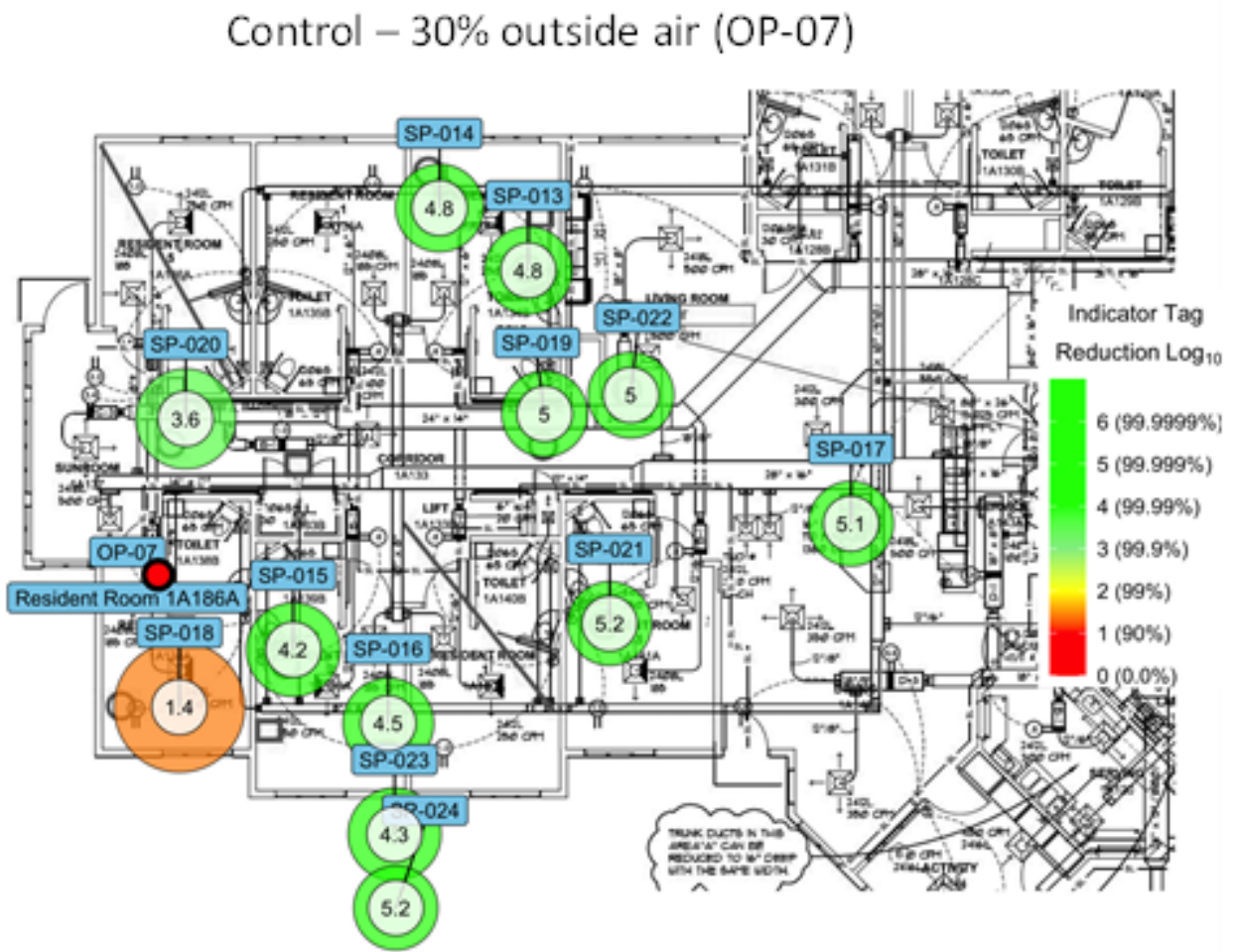

Figure A-3. Experimental (isolation) test space vs. control test space (30\% outside air - staff room) 


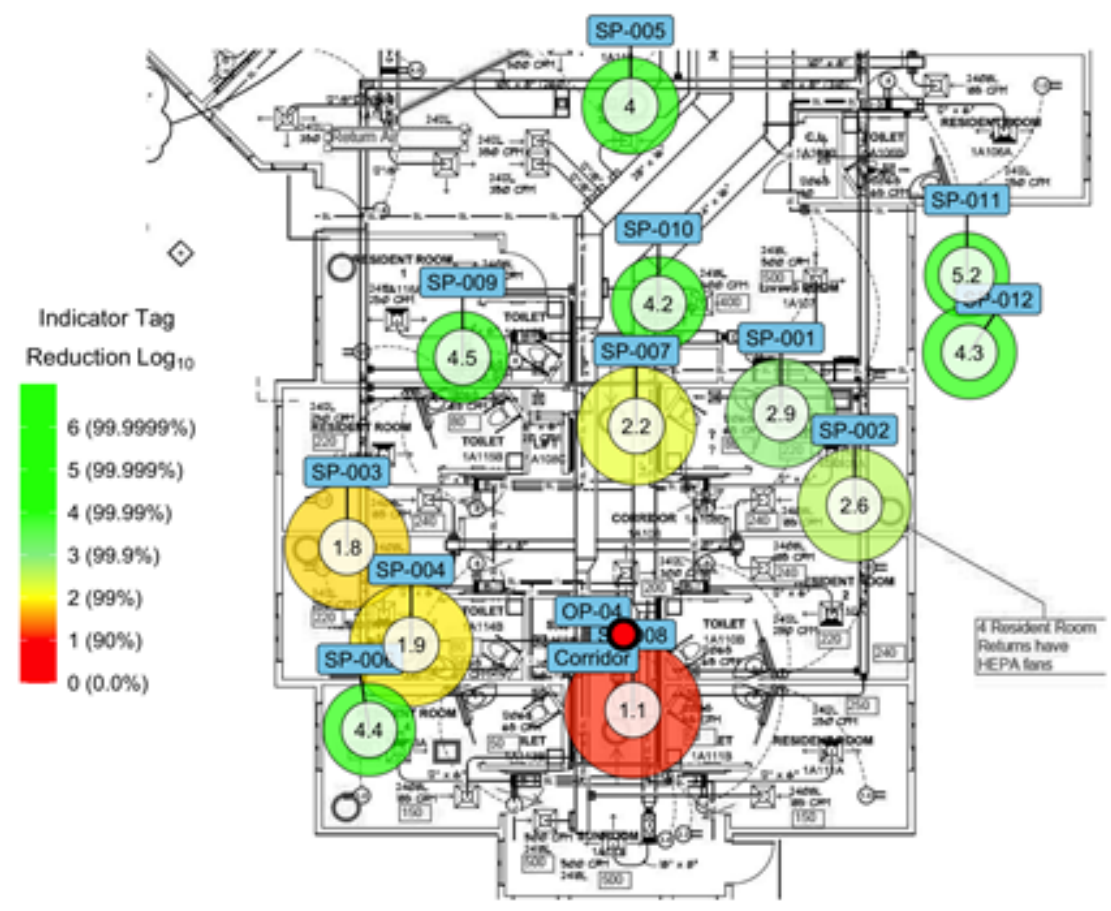

Experimental (isolation) $-30 \%$ outside air (OP-04)

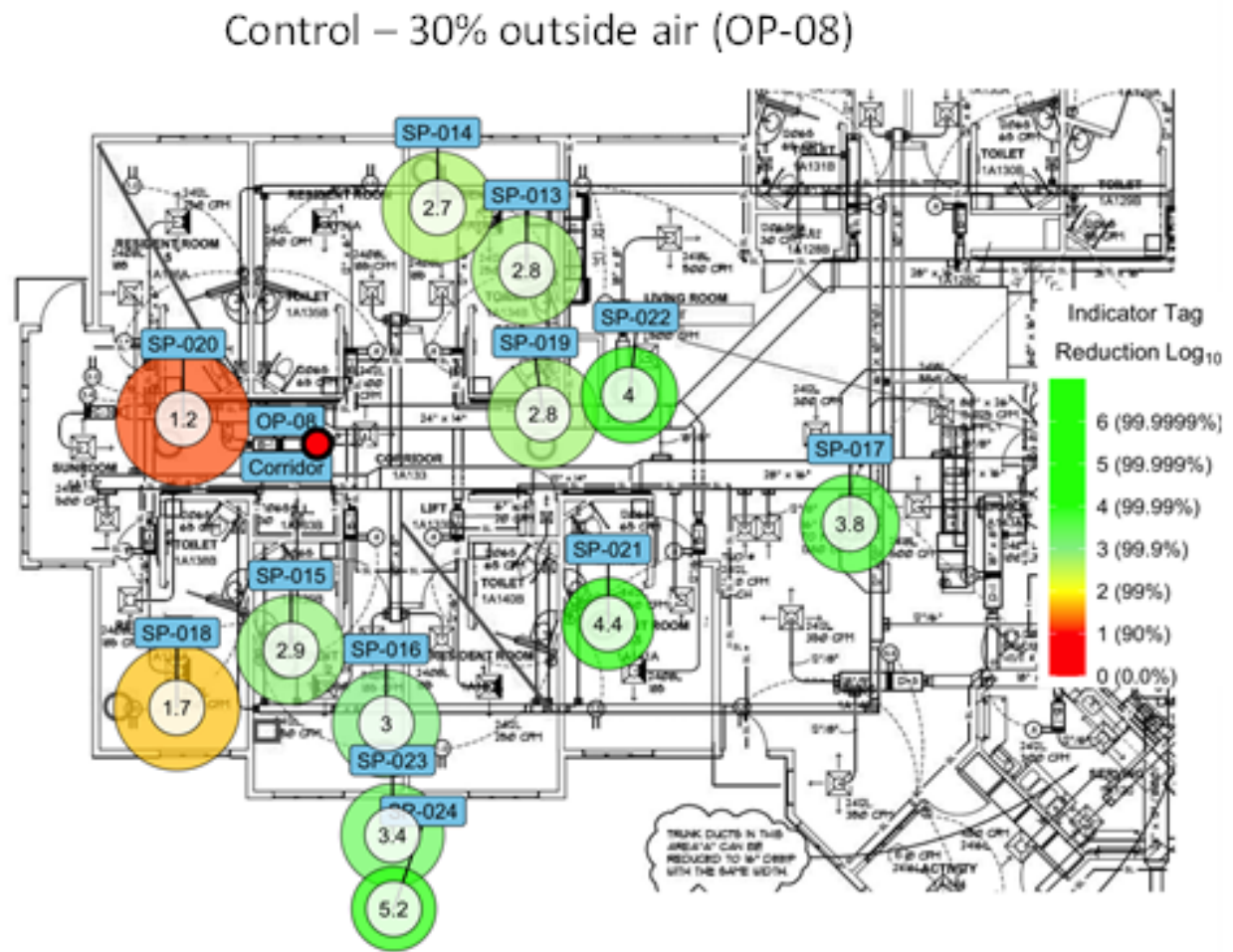

Figure A-4. Experimental (isolation) test space vs. control test space ( $30 \%$ outside air - corridor) 


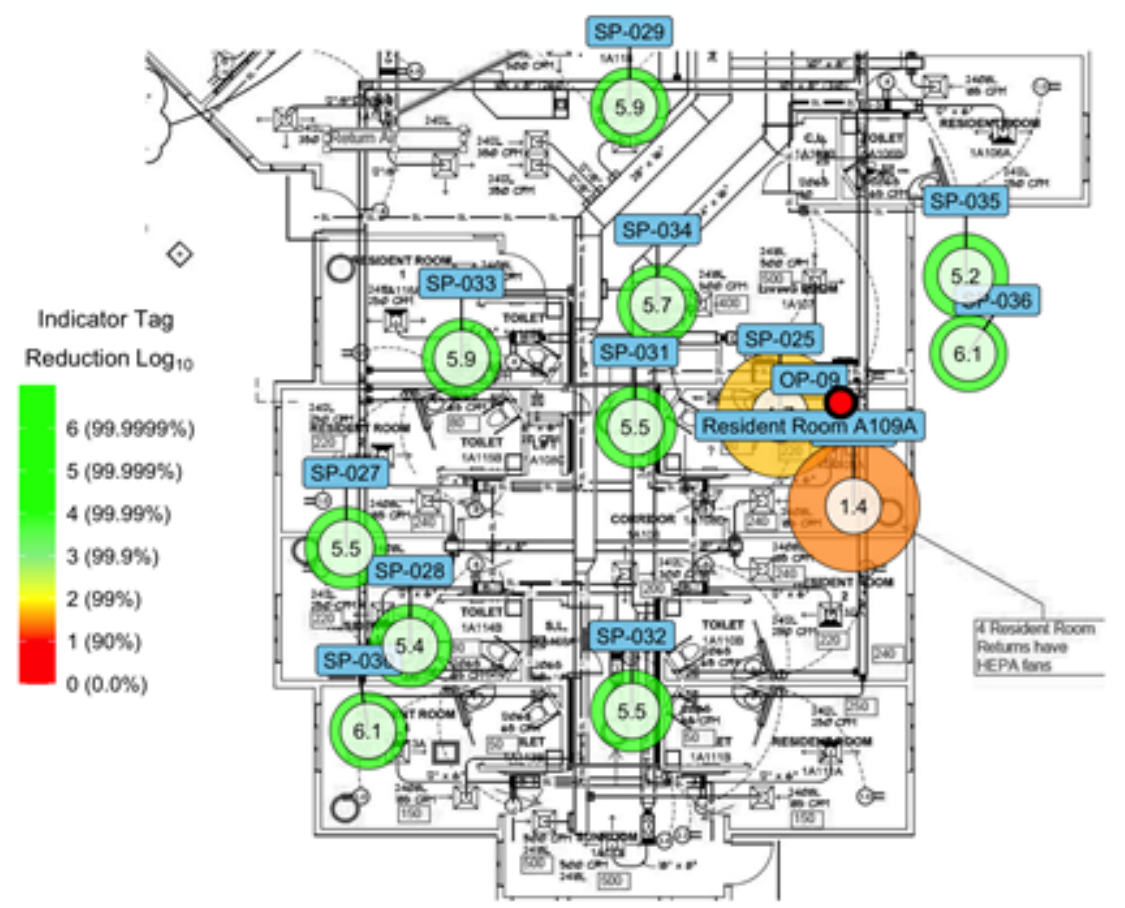

Experimental (isolation) - 100\% outside air (OP-09)

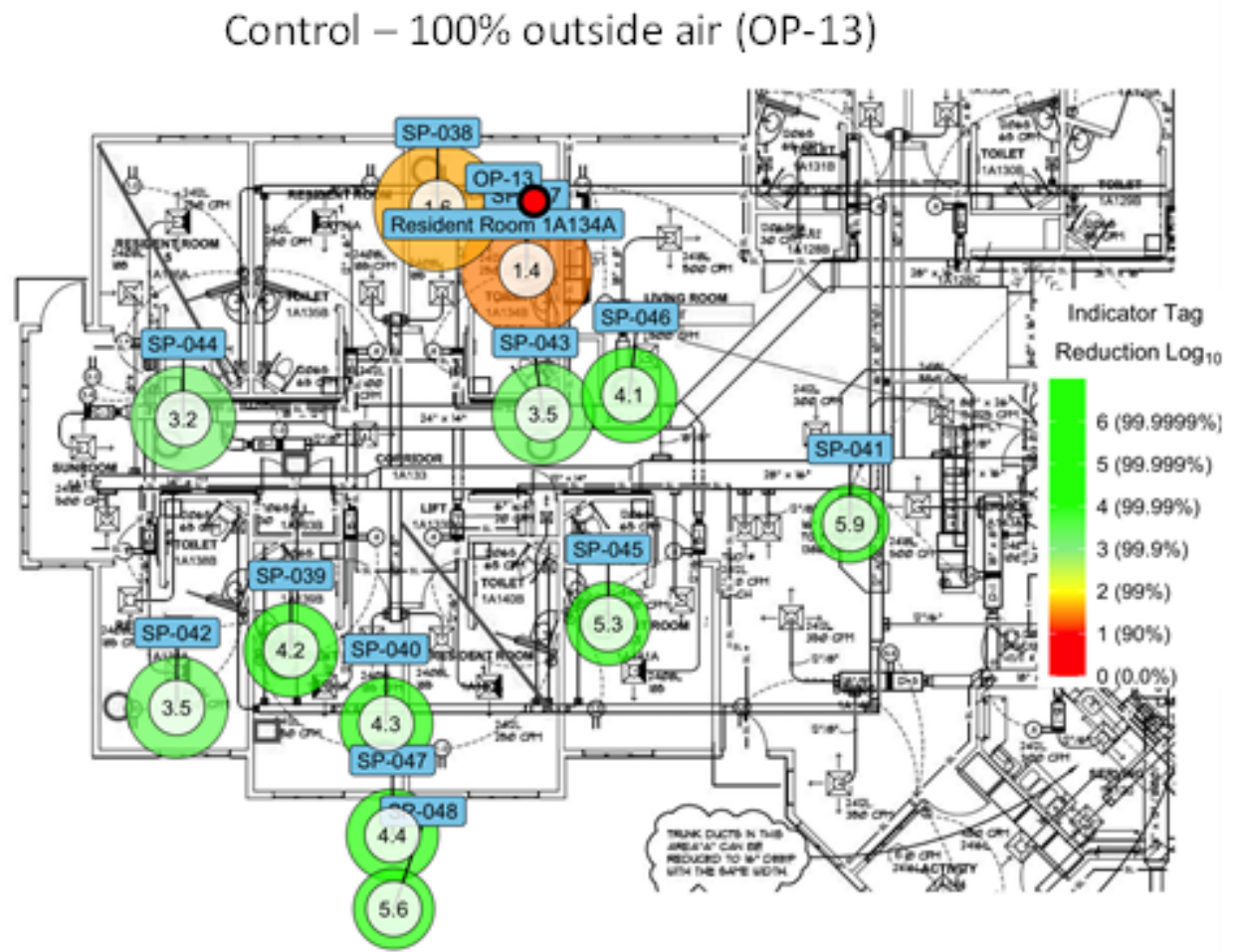

Figure A-5. Experimental (isolation) test space vs. control test space (100\% outside air - resident room 1) 


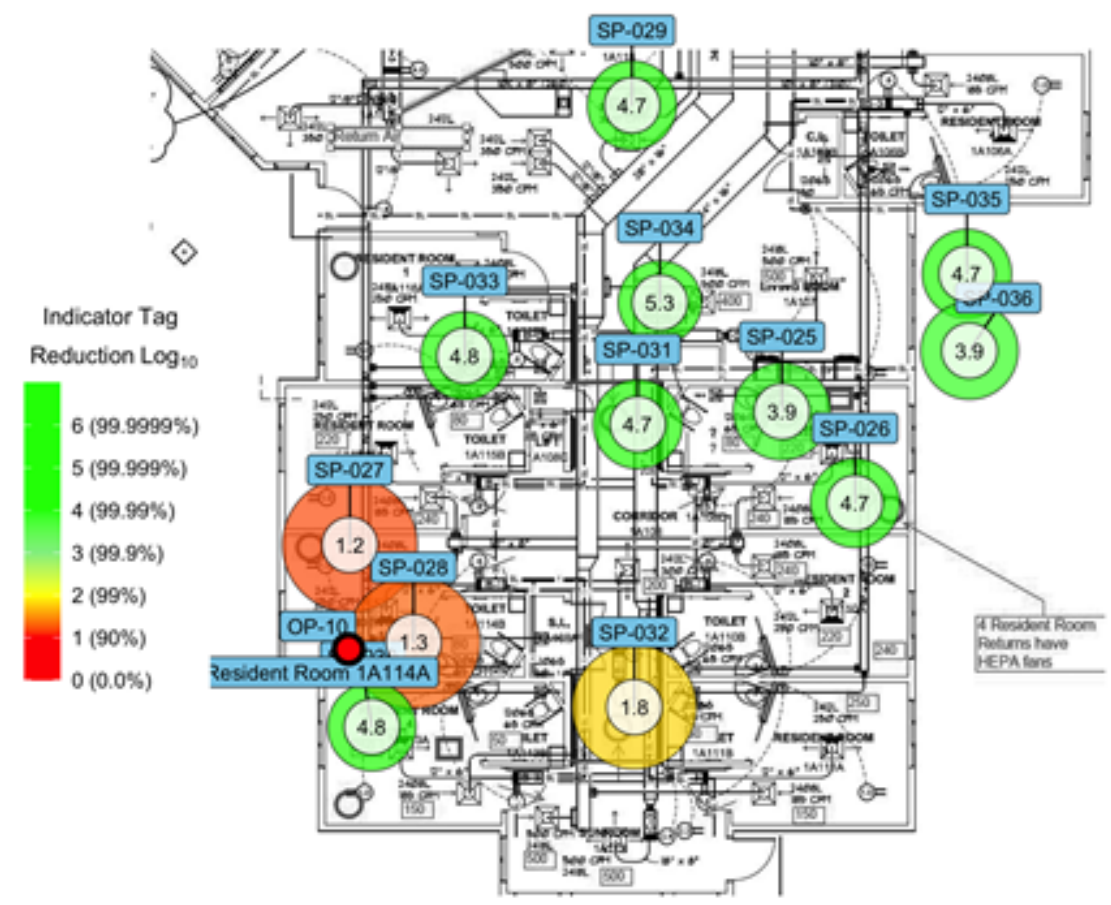

Experimental (isolation) - 100\% outside air (OP-10)

Control $-100 \%$ outside air (OP-14)

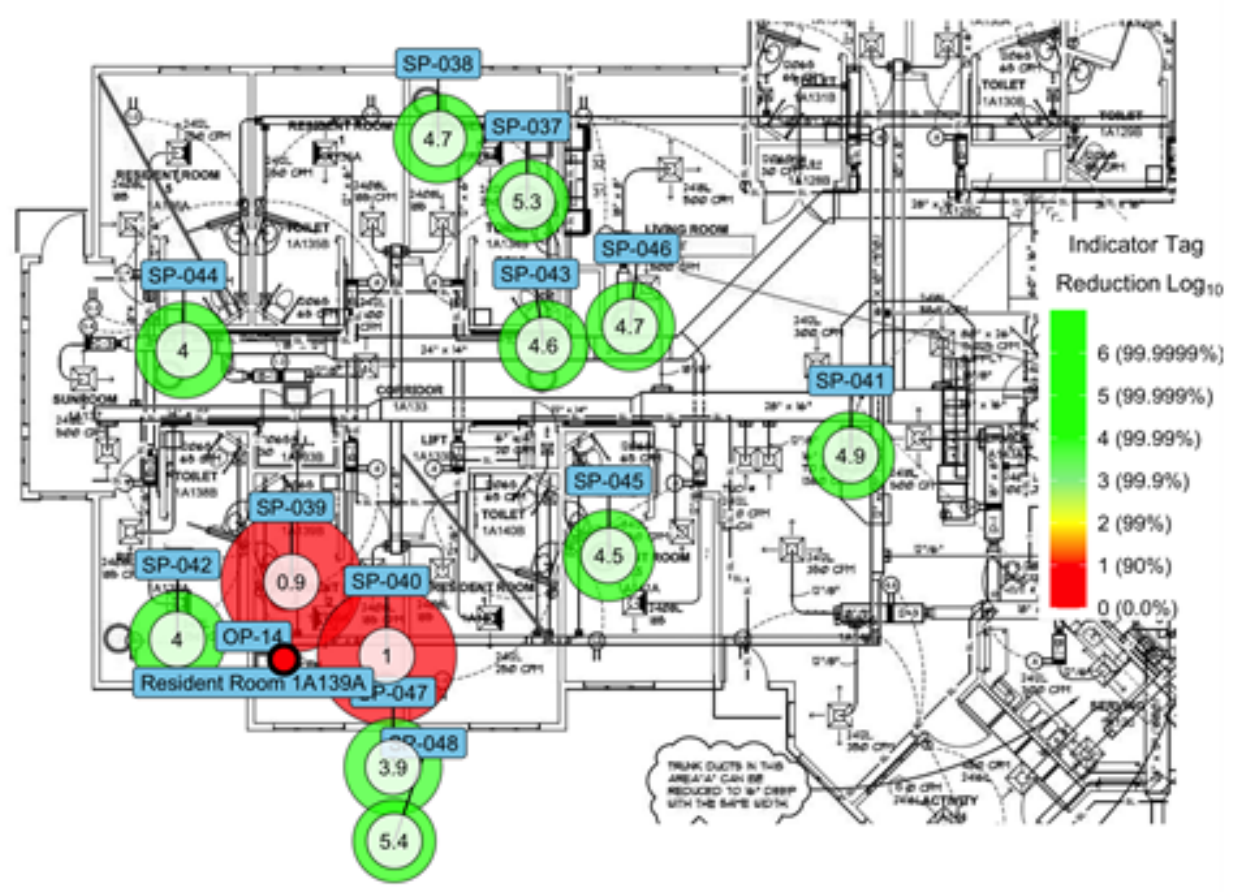

Figure A-6. Experimental (isolation) test space vs. control test space (100\% outside air - resident room 2 ) 


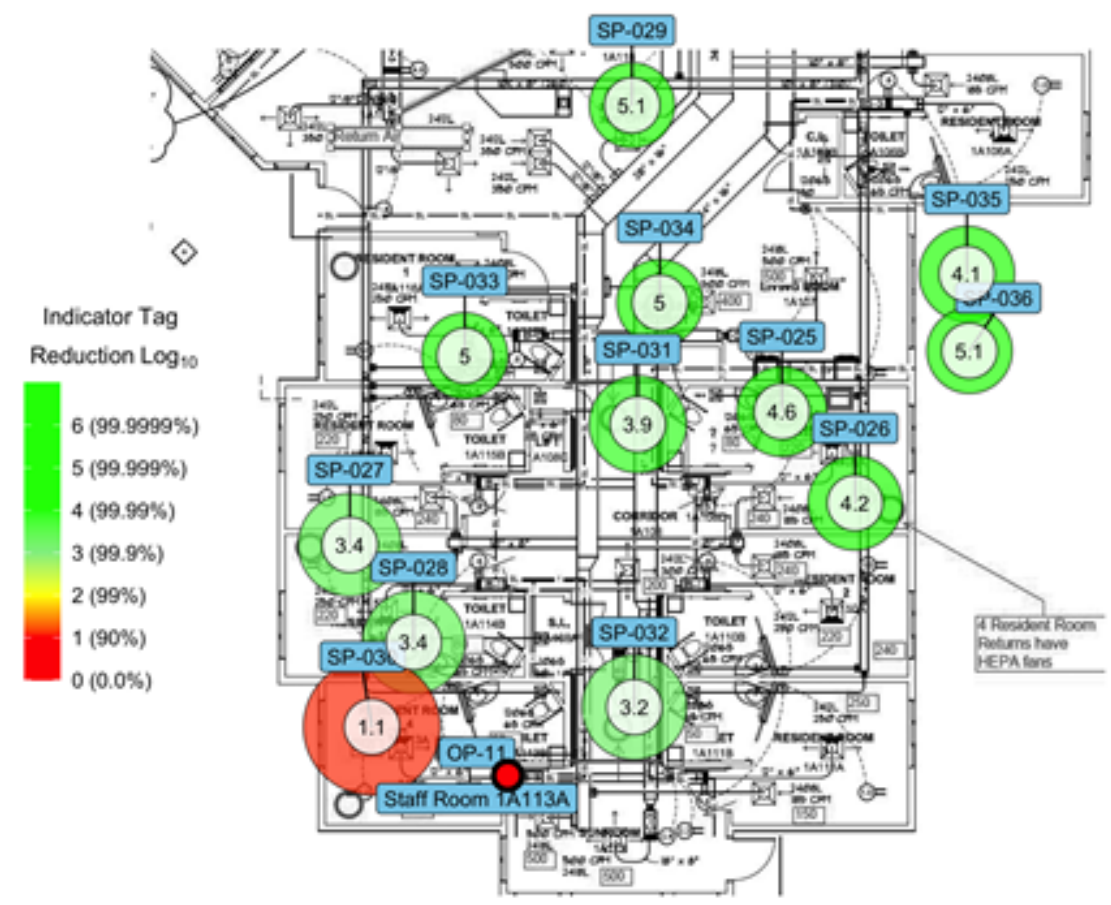

Experimental (isolation) - 100\% outside air (OP-11)

Control $-100 \%$ outside air (OP-15)

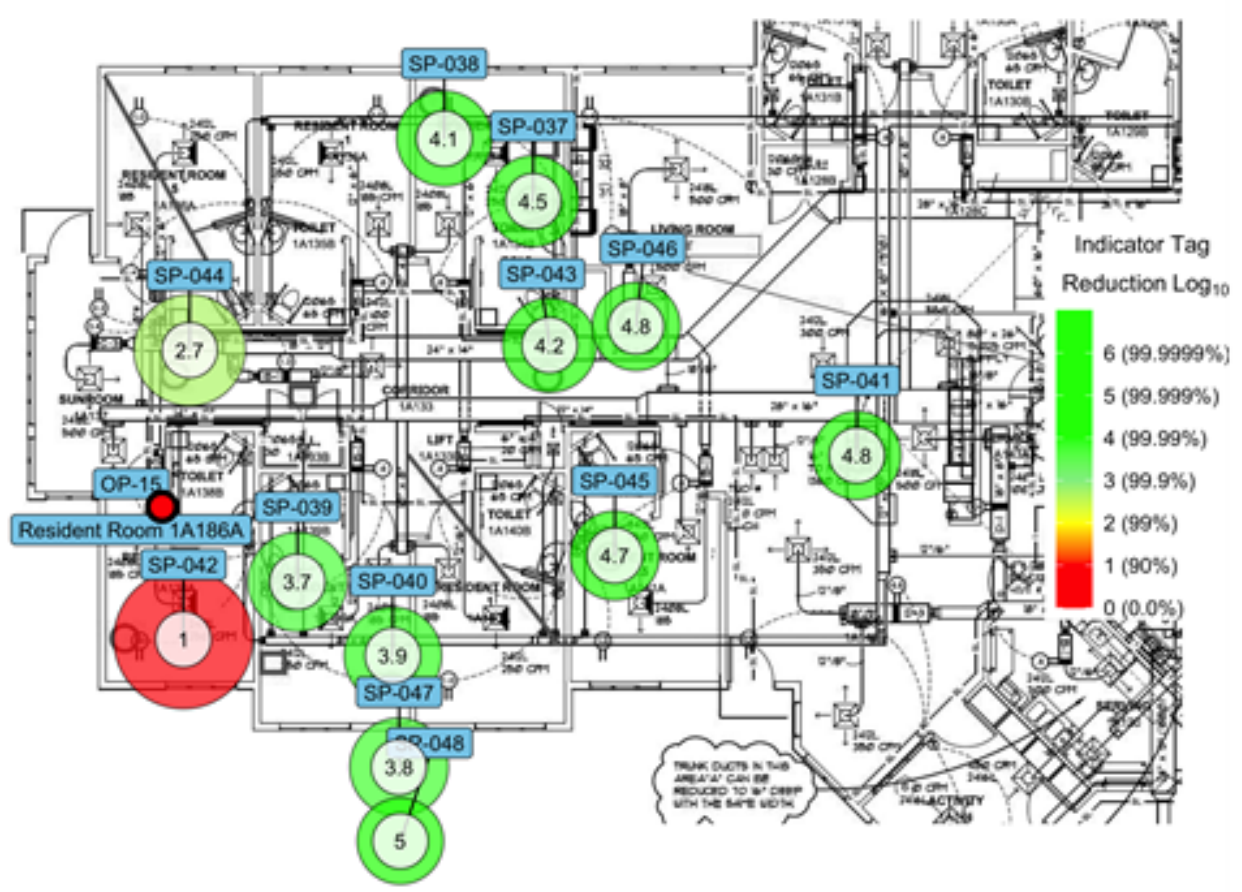

Figure A-7. Experimental (isolation) test space vs. control test space (100\% outside air - staff room) 


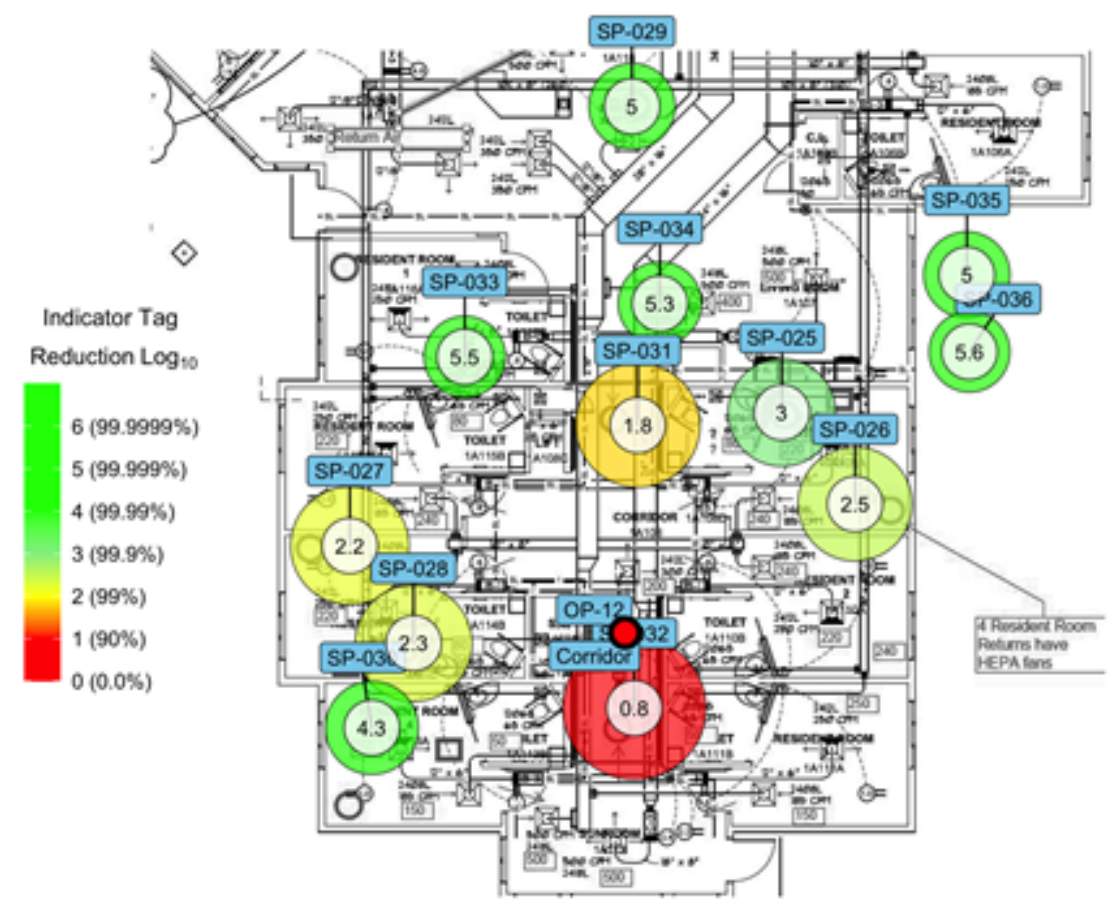

Experimental (isolation) - 100\% outside air (OP-12)

$$
\text { Control - } 100 \% \text { outside air (OP-16) }
$$

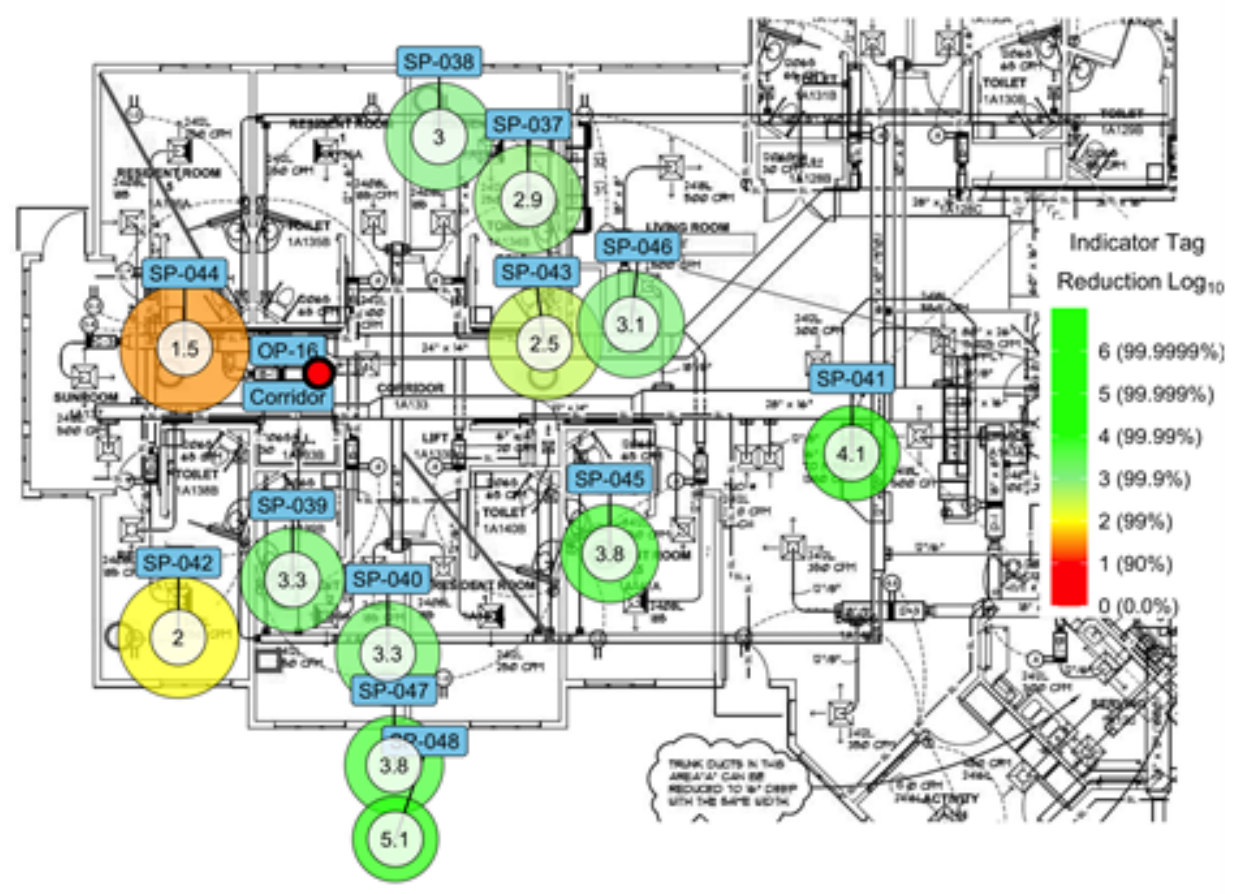

Figure A-8. Experimental (isolation) test space vs. control test space ( $100 \%$ outside air - corridor) 


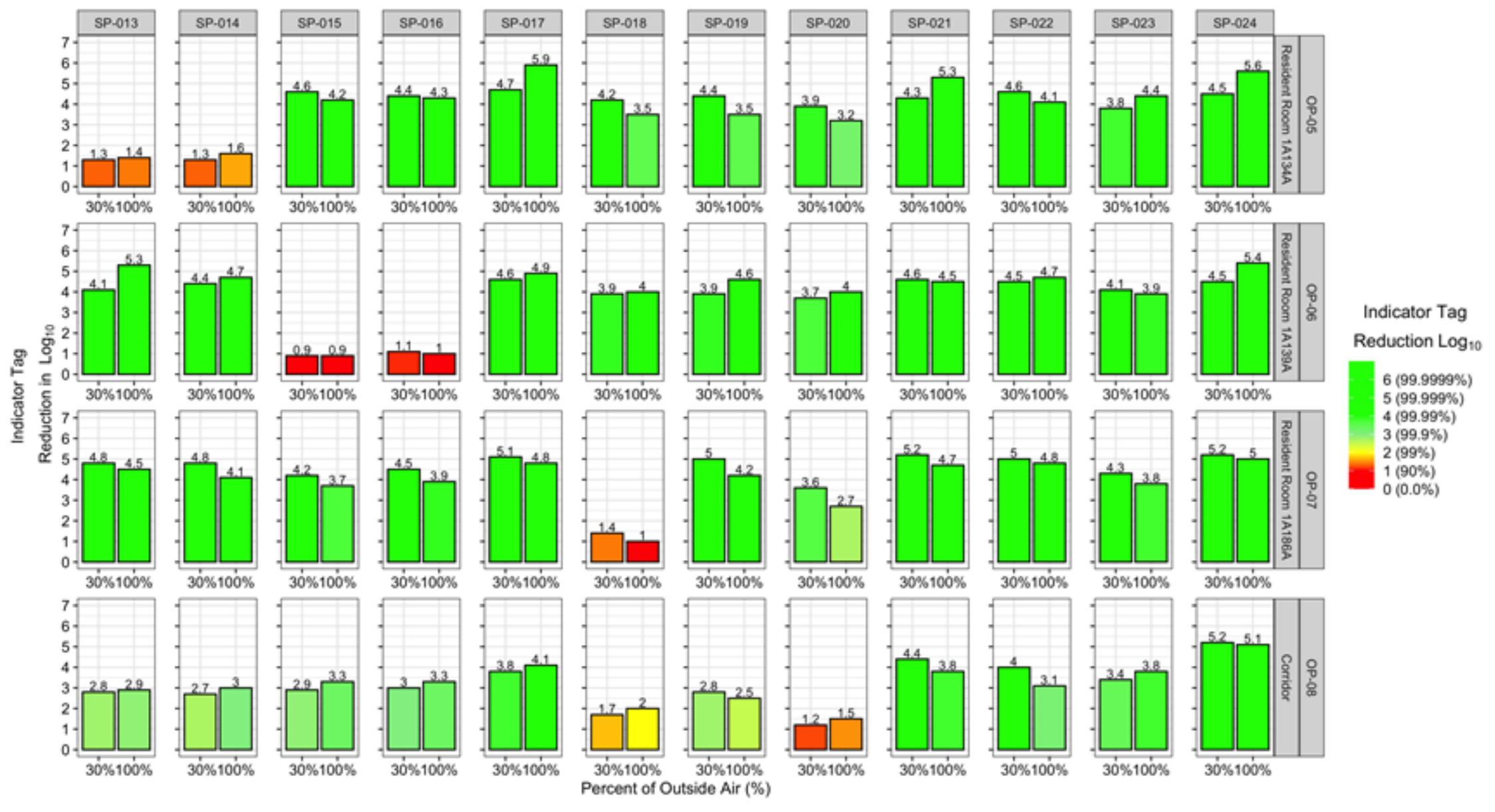

Figure A-9. Control test space - $30 \%$ vs. $100 \%$ outside air 


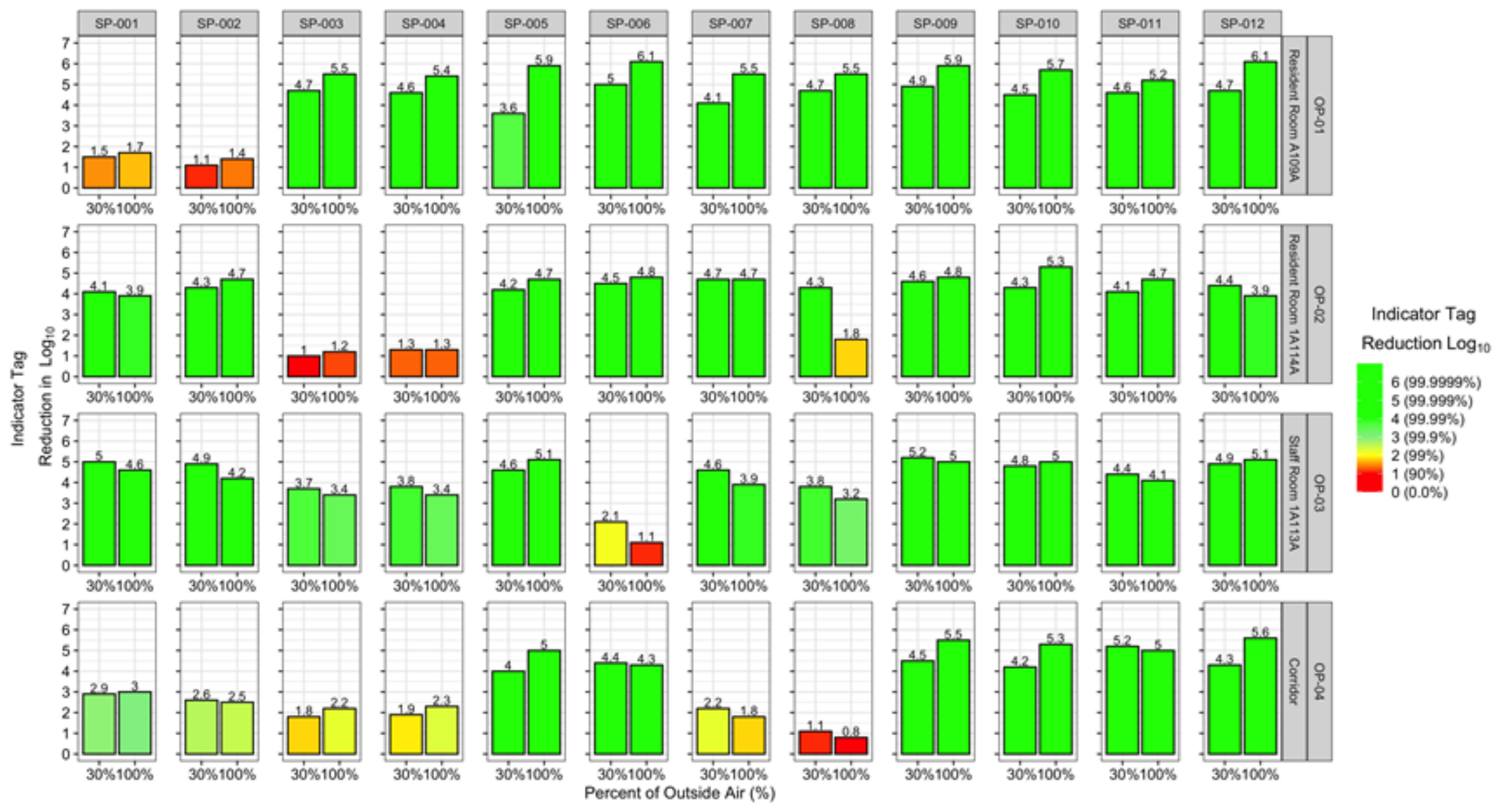

Figure A-10. Experimental (isolation) test space $-30 \%$ vs. $100 \%$ outside air 


\section{Appendix C. Mitigation Technologies}

According to ASHRAE (2020), transmission of SARS-CoV-2 through the air is sufficiently likely that airborne exposure to the virus should be controlled. Changes in building operations, including the operation of HVAC systems, can reduce airborne exposures.

As part of the facility's emergency operation plan, procedural measures and engineering controls should be considered with respect to existing facility capabilities and capabilities to incorporate temporary mitigation technologies. In addition to temporary isolation measures that provide added ventilation, directional airflow, and physical separation, mitigation technologies may also include enhanced air filtration in combination with active and passive carbon, polar ionization, photocatalytic oxidation, and other UV germicidal irradiation technologies. These technologies may be incorporated within existing HVAC systems or provided by ceiling/wall-mounted or portable in-room systems. The use of highly efficient particle filtration can reduce the airborne load of infectious particles. HEPA filters with a MERV of $\geq 19$ can remove $99.9 \%$ of particles greater than or equal to $0.3 \mu \mathrm{m}$, which includes most viruses, bacteria, molds, and volatile organic compounds. The use of high-efficiency filters can, however, diminish the amount of air supplied to the room and cause more air to bypass the filter. In poorly mixed spaces, areas of the room may receive little if any recirculated air and filtration. UV light can kill or inactivate microorganisms within HVAC systems and resident rooms, but long-term exposure can cause damage to the eyes and skin.

Included next is a listing of 15 advanced air filtration and air cleaning technologies beyond the minimum MERV-7 requirement that have the potential to mitigate exposure to COVID-19 and other respiratory diseases in skilled nursing facilities and similar residential care environments. For each technology, removal efficiency is presented, along with energy requirements, impact to existing systems, cost, and operations and maintenance requirements. 


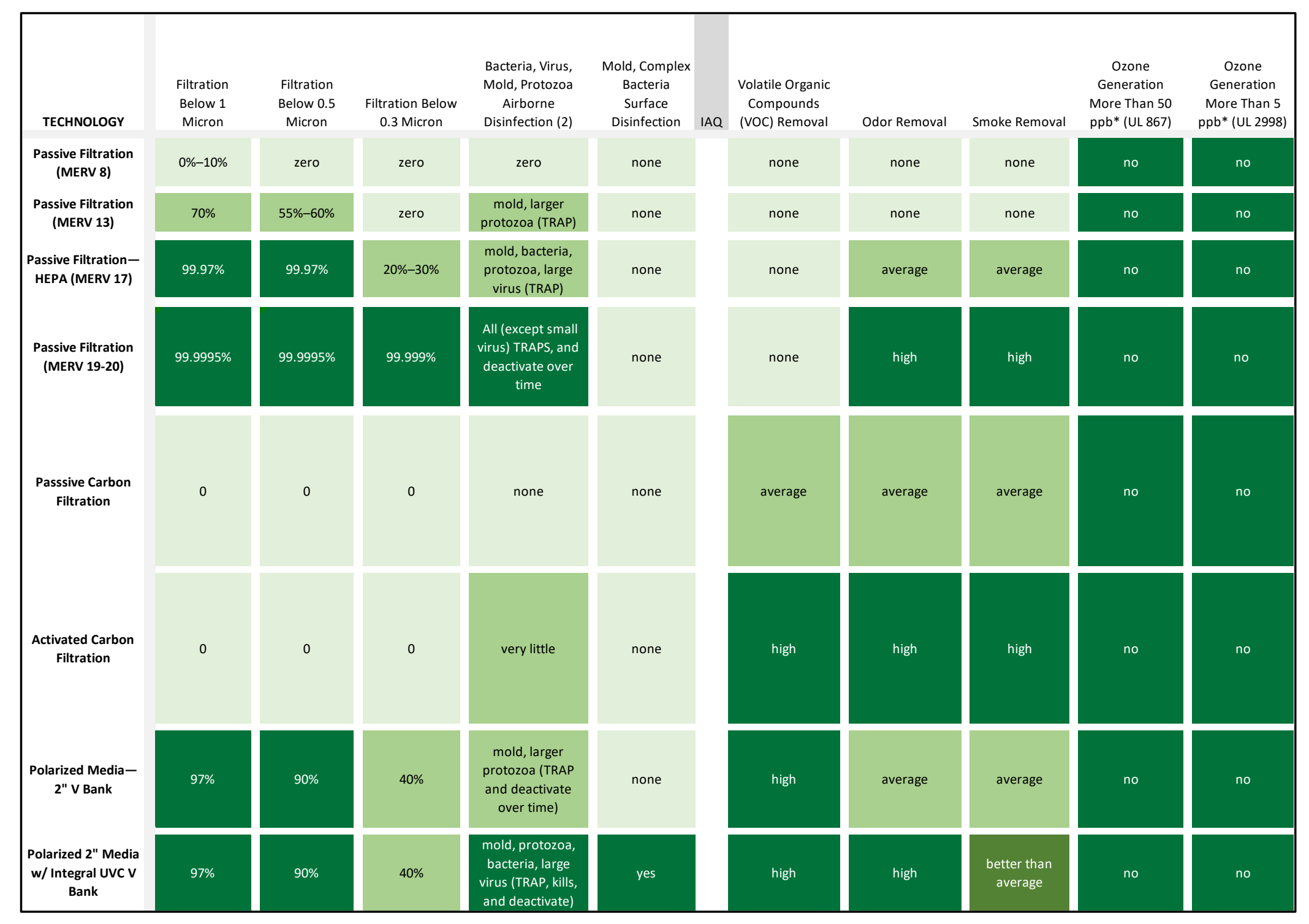




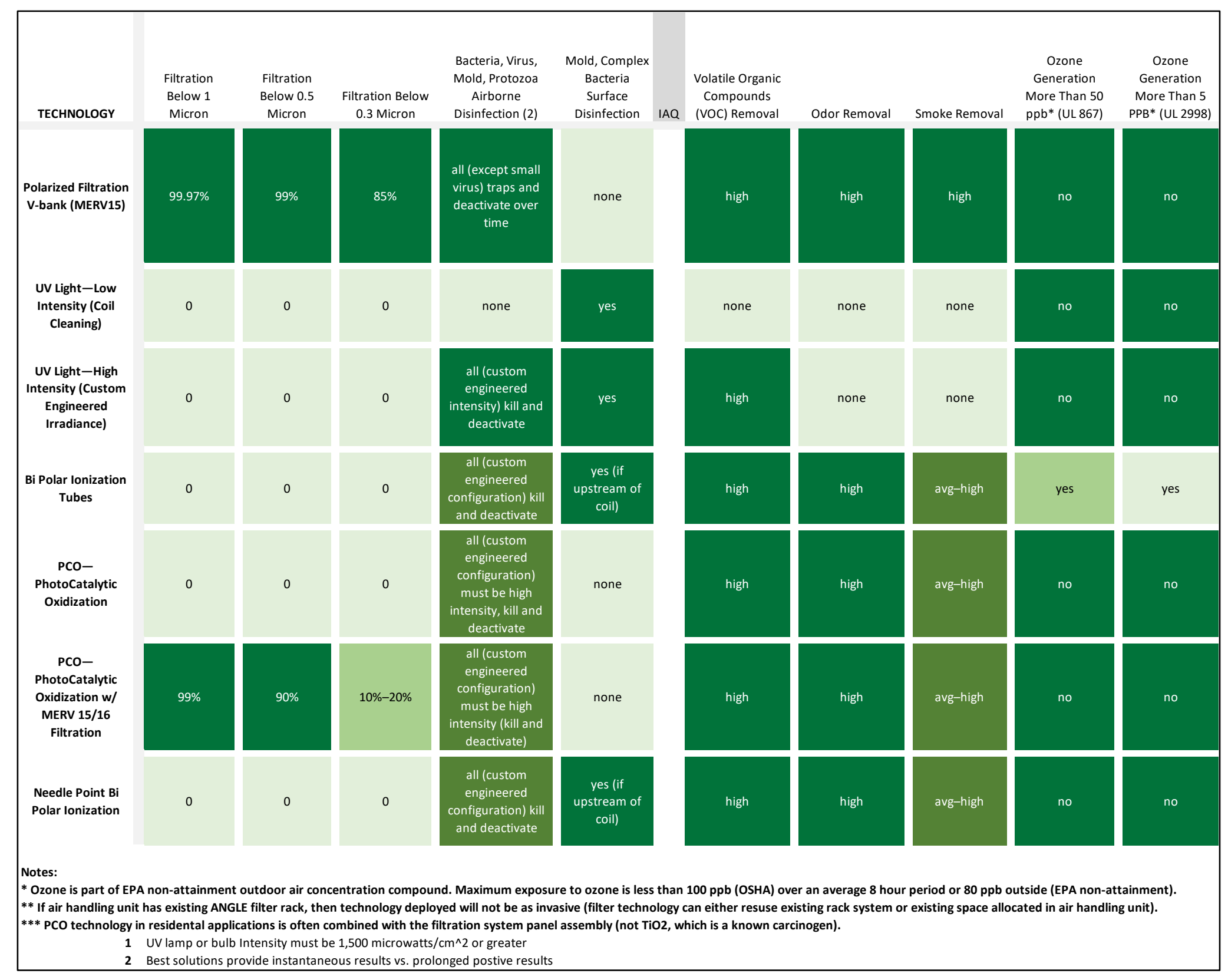




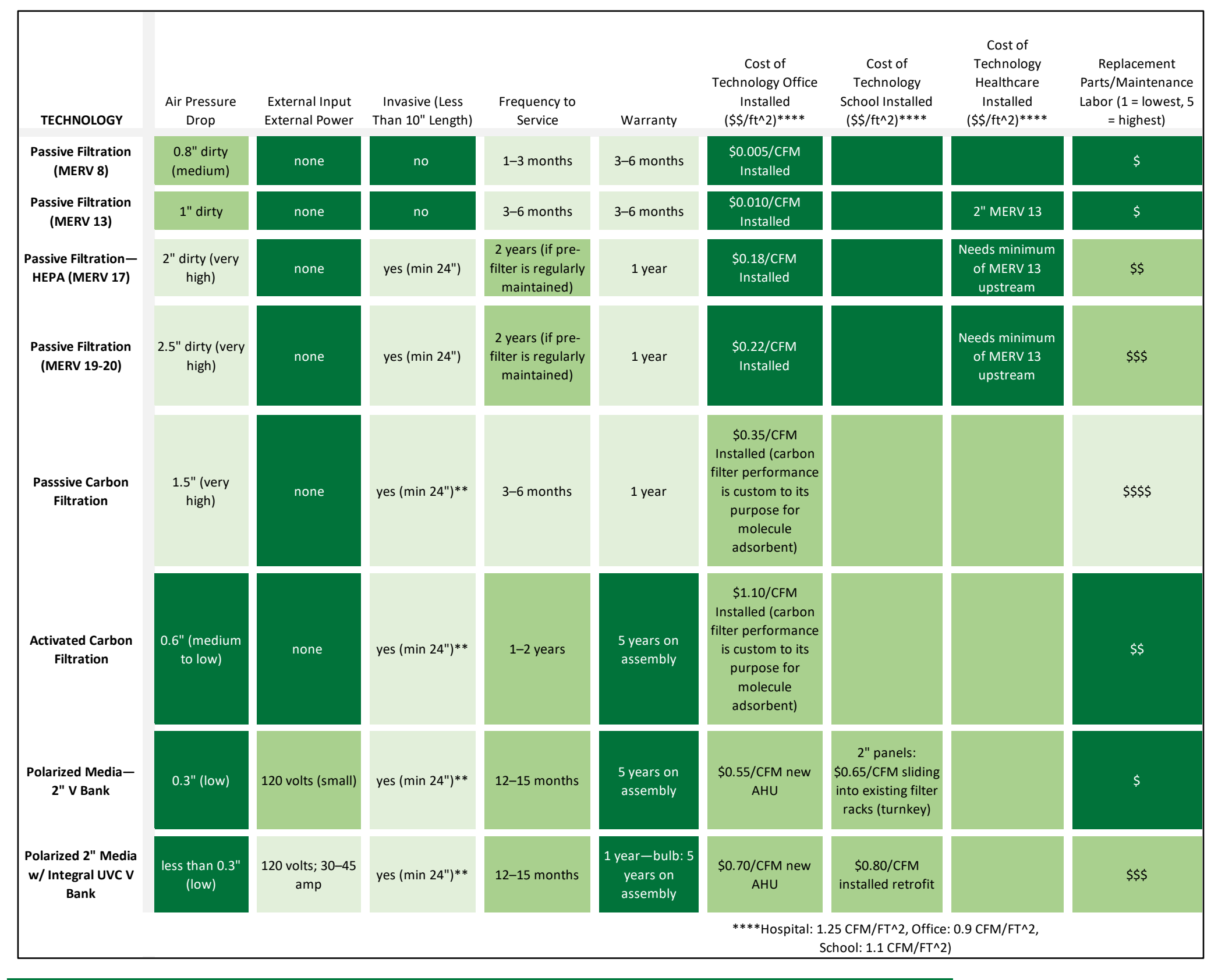


Ventilation in Residential Care Environments

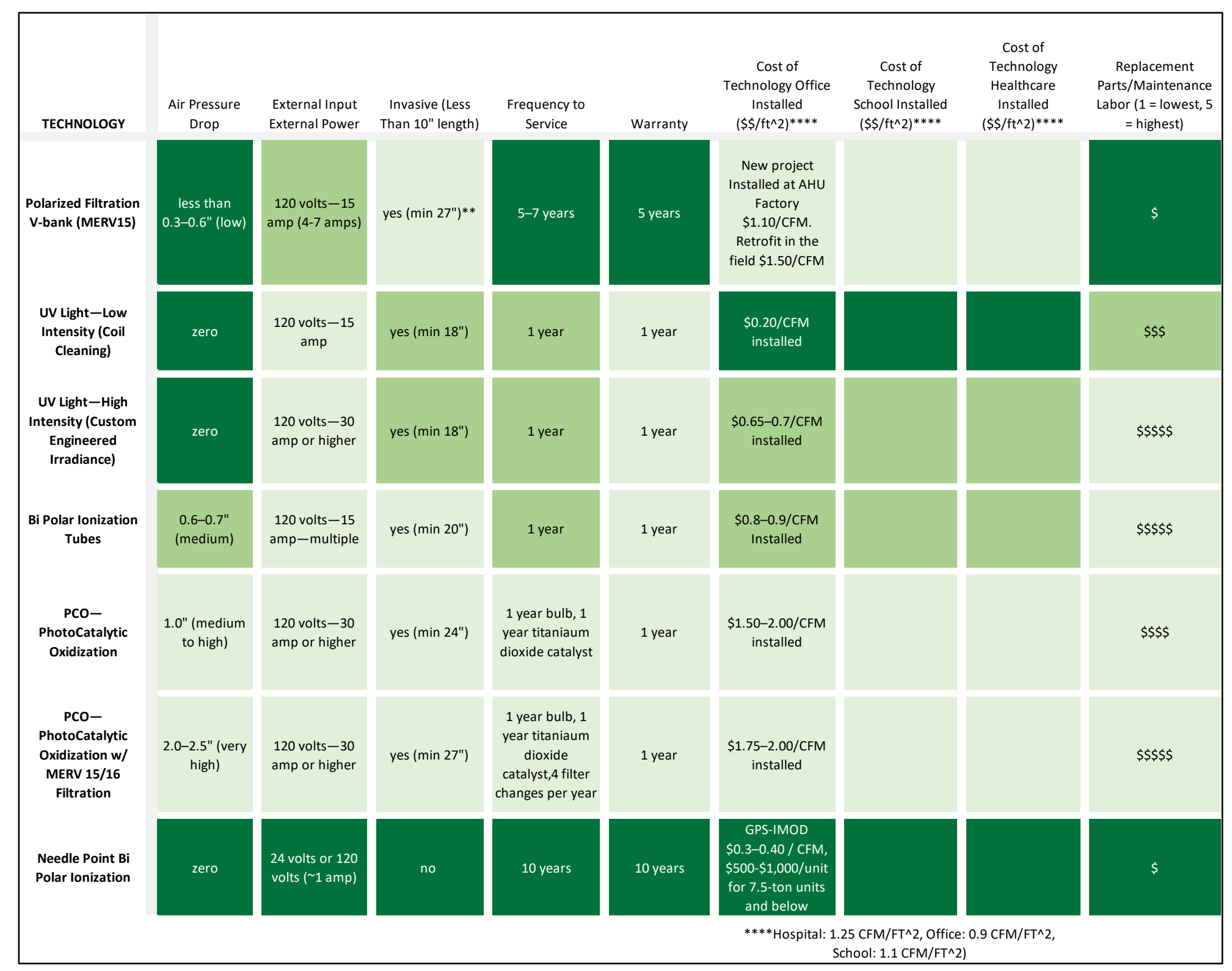

Source: M. Donovan and R. Lautz, Affiliated Engineers Inc. 
